Rodrigo Amaral Lapa

\title{
Museu, Arte e Tecnologia: \\ As transformações dos museus contemporâneos influenciadas pelas TIC's
}

\author{
Versão Corrigida
}

Dissertação apresentada ao Instituto de Arquitetura e Urbanismo da USP -

São Carlos como parte dos requisitos para a obtenção do título de Mestre em Arquitetura e Urbanismo.

Orientador: Prof. Assoc. Dr. Azael Rangel Camargo

São Carlos, 2011. 
AUTORIZO A REPRODUÇÃO E DIVULGAÇÃO TOTAL OU PARCIAL DESTE TRABALHO, POR QUALQUER MEIO CONVENCIONAL OU ELETRÔNICO, PARA FINS DE ESTUDO E PESQUISA, DESDE QUE CITADA A FONTE.

Ficha catalográfica preparada pela Seção de Tratamento da Informação do Serviço de Biblioteca - EESC/USP

L299m

Lapa, Rodrigo Amaral.

Museu, arte e tecnologia : as transformações dos museus contemporâneos influenciadas pelas TIC's / Rodrigo Amaral Lapa ; orientador Azael Rangel Camargo. São Carlos, 2011 .

Dissertação (Mestrado - Programa de Pós-Graduação em Arquitetura e Urbanismo e Área de Concentração em Teoria e História)-Instituto de Arquitetura e Urbanismo de São Carlos da Universidade de São Paulo, 2011.

1. Museu. 2. Arte. 3. Tecnologia da informação e da comunicação. 4. Arquitetura. 5. Sistemas interativos. I. Título. 


\section{FOLHA DE IULGAMENTO}

Candidato: Arquiteto e Urbanista RODRIGO AMARAL LAPA

Título da dissertação: "Museu, arte e tecnologia: as transformações dos museus contemporâneos influenciadas pelas TIC's".

Data da defesa: 10/04/2012

Comissão Julgadora:

Prof. Associado Azael Rangel Camargo

(Instituto de Arquitetura e Urbanismo/USP)

Prof. Dr. David Moreno Sperling

(Instituto de Arquitetura e Urbanismo/USP)

Prof $^{\mathrm{a}}$ : Dr ${ }^{\mathrm{a}}$. Verlete Aparecida Benevente

(Universidade de Uberaba - MG)
Resultado:

AVROURDO

APROVADO

$\triangle P R O V A D O$

Coordenador do Programa de Pós-Graduação em Arquitetura e Urbanismo:

Prof. Titular Renato Luiz Sobral Anelli

Presidente da Comissão de Pós-Graduação:

Prof. Associado Paulo Cesar Lima Segantine 


\section{Agradecimentos}

\section{Aos mestres}

Prof. Assoc. Dr. Azael Rangel Camargo pela atenção, apoio e orientação sempre aberta e estimulante e aos demais mestres e professores que contribuíram com diálogos, informações e sugestões durante as disciplinas cursadas no Instituto de Arquitetura da USP São Carlos.

\section{Aos familiares}

Meus pais Regina Lúcia de Lima Amaral Lapa e Euclides Amaral Lapa Filho, pela paciência e suporte incondicional durante todo meu percurso.

\section{Aos amigos}

A todos aqueles que de alguma forma contribuíram direta ou indiretamente em discussões, conversas e reflexões durante a elaboração desta dissertação.

Especialmente a Elizabeth Gorgone pela ajuda nos momentos difíceis e pela revisão cuidadosa do texto. 
À Regina e Euclides. 
O museu é o confronto das metamorfoses.

(MALRAUX, 1947) 


\section{Índice}

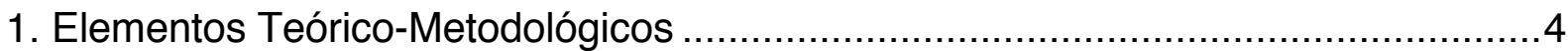

1.1 Contextualização da pesquisa e problematização …................................... 4

1.1.1 O Museu como Instituição de interesse público.........................................

1.1.2. Os museus, as TIC's e a sociedade da informação ...................................10

1.1.3 Arte, tecnologia e interatividade. ..................................................... 12

1.2 Definição do objeto e formulação da hipótese ................................................. 14

1.3 Estratégia metodológica e evolução da pesquisa ......................................15

1.3.1 Princípios teóricos da estratégia metodológica......................................17

1.3.2 Matrizes da pesquisa teórica. ...............................................................20

1.3.3 O sistema de signos entre arte, museu tecnologia. ...............................23

1.3.4 A cibernética como referência teórica ..............................................25

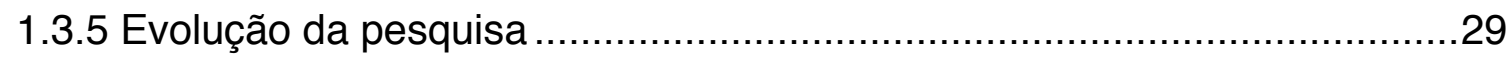

1.3.6 Organização da dissertação. .............................................................30

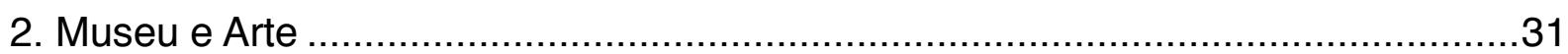

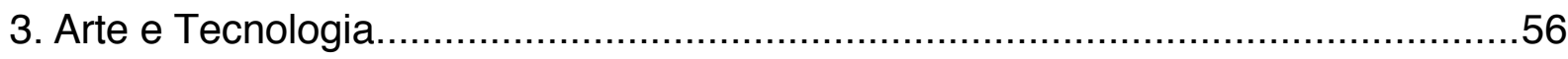

3.1 As transformações da cultura da imagem a partir do pós-moderno .................57

3.2 Arte Eletrônica: Uma Trajetória............................................................88

3.3 Os primeiros Institutos de Pesquisa Internacionais .......................................97

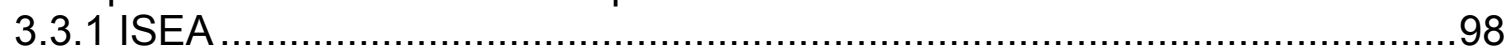

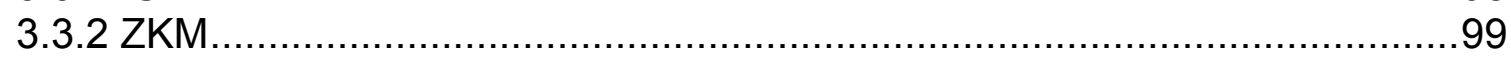

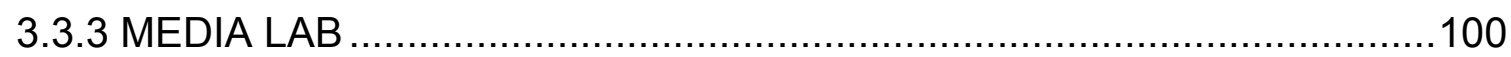

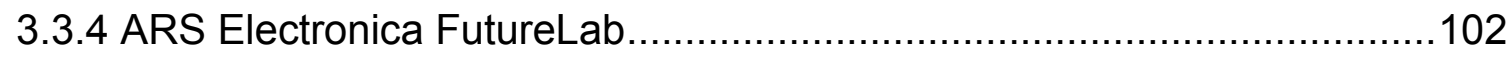

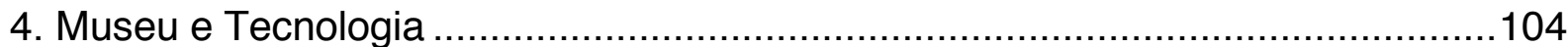

4.1 Arte e Interação nos Museus Brasileiros ..............................................136

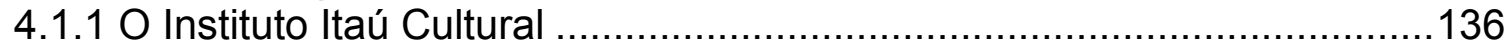

4.1.2 Museu da Língua Portuguesa ......................................................... 144

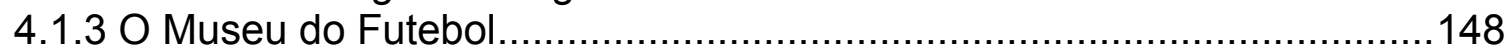

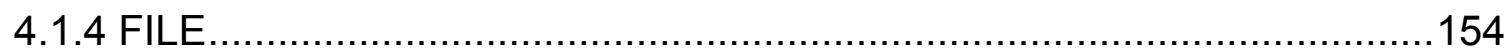

4.2 Novos rumos no cenário internacional ............................................ 156

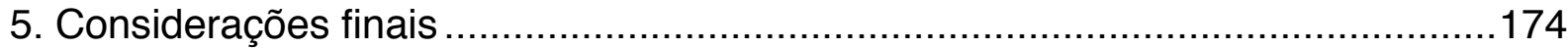

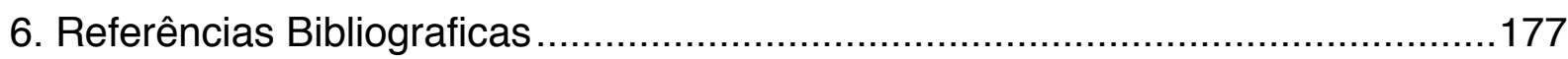

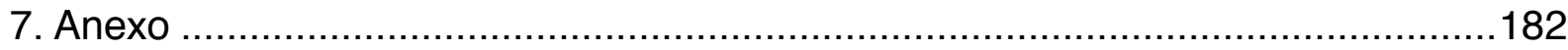




\section{Resumo}

LAPA, R. A. (2011) Museu, Arte e Tecnologia: As Transformações do Museu Influenciadas pelas TIC's no séc. XXI. Dissertação (Mestrado) - Instituto de Arquitetura e Urbanismo, Universidade de São Paulo, São Carlos, 2011.

Este trabalho aborda o tema do museu por meio de suas transformações no contexto da Sociedade da Informação. Do ponto de vista teórico-metodológico, estabelece análises sobre os aspectos que envolvem museu, arte e tecnologia, proporcionados pela interação entre arte e espectador. Discute as possibilidades oferecidas pelas TIC's (Tecnologias da Informação e Comunicação) e sua relevância no âmbito social, cultural e artístico como instrumento agregador e transformador das funções da arte e da arquitetura nos museus.

Busca também compreender os processos de criação e desenvolvimento da arte e sua integração com a arquitetura dos museus no desenho de obras e espaços interativos. O trabalho busca identificar a incorporação destas tecnologias e discutir suas principais possibilidades, riscos e desafios. Enfatiza a importância do aspecto multidisciplinar na concepção dos novos museus e nas estratégias de organização do espaço museográfico.

Palavras-chave: Museu, Arte, Tecnologia da Informação e da Comunicação, Arquitetura, Sistemas Interativos. 


\section{Abstract}

LAPA, R. A. (2011) Museum, Art and Technology: Transformations of the Museum Influenced by ICTs in the XXI's Century. Thesis (MA) - Institute of Architecture and Urbanism of University of São Paulo, São Carlos, 2011.

This work addresses the theme of the museum space transformations in the context of the Information Society. From the standpoint of theoretical and methodological framework, seeks to establish benchmarks and qualitative aspects that involve cognitive and spatial relationships between the Museum, Art and Technology, provided mainly by the creation of interactive and integrated digital systems. It discusses the possibilities offered by new technologies and their relevance in the social, cultural and art as an aggregator tool and processor functions of Arts and Architecture.

It's scope understand the processes of creation and development of art and its integration with architecture in the conception of museums that use interactive systems. The study points to a tendency to incorporate these technologies in order to make the public more involved and communicative with art and architecture. Emphasizes the importance of the multidisciplinary aspect designing new museums, it's social and cultural aspects, and the strategies of museological space.

Keywords: Museum, Art, Information and Communication Technology, Architecture, Interactivity, Interactive Systems. 


\section{Capítulo 1. Elementos Teórico-Metodológicos}

O capítulo inicial deste trabalho é basicamente metodológico e aqui serão apresentados os elementos teóricos que constituem o embasamento desta pesquisa. Nos tópicos seguintes, será realizado o delineamento do objeto e a formulação da hipótese de trabalho. Em seguida, será descrita a estratégia metodológica e a forma como a dissertação foi estruturada.

\subsection{Contextualização da pesquisa e problematização}

A chamada Sociedade do Conhecimento, ou Sociedade da Informação, é atualmente o paradigma utilizado pela maioria dos pesquisadores e filósofos contemporâneos para analisar os fenômenos políticos, sociais, econômicos e culturais que vivemos desde que a convergência da informática com as telecomunicações (Telemática) transformou a maneira como lidamos com o envio e recebimento de dados digitalizados.

Entre as diferentes visões a respeito das potencialidades dessa tecnologia, existe uma clara polarização sobre o papel exercido por ela e a sua função enquanto facilitadora da inclusão social e indicadora de melhoria da qualidade de vida.

A convergência tecnológica é a consequência da aproximação dos meios de comunicação e da informática, que vem alterando as relações de tempo e espaço desde a consolidação da internet e dos sistemas integrados de telecomunicações.

Para Castells (2000), fragmentação, descentralização e interdependência, são categorias que alteraram as relações de poder e permitiram novas interações sociais e institucionais. Por meio de mudanças que se estendem desde o sistema 
produtivo à organização social, a convergência é um dos alicerces da Sociedade do Conhecimento.

Conceitualmente, a tecnologia pode ser assumida como algo bom ou ruim, conforme a linha de pensamento, mas com certeza não é neutra e na maioria das vezes atende a algum discurso ideológico que a legitime como uma solução ideal para todos os problemas da humanidade.

O desenvolvimento deste trabalho teve como objeto geral, compreender as dimensões culturais, artísticas e arquitetônicas da criação dos museus contemporâneos e suas transformações na atual Sociedade do Conhecimento.

Uma das principais premissas aqui colocadas é que a Tecnologia da Informação, as novas Mídias e a Sociedade da Informação alteraram as formas de percepção e produção cultural no mundo contemporâneo e os museus se tornaram instituições de alto interesse econômico, cultural e social.

É evidente a importância do processo de evolução tecnológica da humanidade em condicionar o surgimento de novos parâmetros e paradigmas da sociedade a cada época, alterando a organização e constituição de sua arquitetura e de seus espaços.

Desta forma, o espaço cibernético se tornou uma parte importante de nossa realidade, um espaço próprio da comunicação e do pensamento humano da nossa era. Pode-se supor as implicações que isso causa em todas as áreas, no campo da economia, da educação, do trabalho, da vida política, das questões dos direitos e da produção cultural.

O que se pretende aqui é realizar uma análise das mudanças de paradigmas dos museus na sociedade digital e suas implicações e potencialidades associadas à arte e à arquitetura. 
Para tanto, foram formuladas as seguintes questões:

1. Qual a relação entre arte, tecnologia e interação nos museus contemporâneos?

2. Quais as possibilidades, riscos e desafios do uso das TIC's nestes museus?

3. Qual o papel da arquitetura nestes museus?

A partir de uma conceituação preliminar, foi realizado o estudo de configurações espaciais induzidas pela tecnologia e pelas novas formas de fruição e percepção estética presente em alguns museus e espaços culturais contemporâneos.

A instituição museu sofreu períodos de crise e fragilidade crítica, mas seguiu ampliando e legitimando seu papel de representatividade nas sociedades contemporâneas. É inegável seu valor como instituição de referência e de síntese, capaz de evoluir e oferecer modelos alternativos para assinalar, caracterizar e transmitir os valores e signos culturais do seu tempo.

Destaca-se aqui a importância desta pesquisa em analisar e discutir novos parâmetros de concepção dos espaços de cultura contemporâneos, considerando suas necessidades técnicas e referências simbólicas em seus distintos níveis de interface com a sociedade e a cidade.

Com isso buscou-se contribuir para as pesquisas desenvolvidas neste Instituto através do grupo de pesquisas e-urb, discutindo os fenômenos de transformação dos espaços e serviços da cidade contemporânea influenciados pelas Tecnologias da Informação e Comunicação (TIC's).

As TIC's e a Internet, por meio de sua ubiquidade e controle total na organização dos serviços telemáticos, se tornou indispensável para o cidadão exercer seus direitos e se comunicar com o poder público. 
A miniaturização, a convergência de tecnologias e a conexão em rede transformaram o modo como vivemos e pensamos e isso também se observa na área da produção cultural. Segundo uma análise materialista, o ato de transformar a natureza por meio da técnica segue um movimento dialético, onde a cada movimento de transformação da natureza o homem também se modifica.

Podemos entender o museu, em sua essência, como um espaço de comunicação e, apesar de todas as transformações, o museu sempre foi um espaço de narrativas.

Já a arte, o elo que une tecnologia e museu, foi analisada em suas relações e desdobramentos no espaço, tensionando, expondo e interagindo com o museu, a tecnologia e as pessoas.

O elemento que perpassa toda a reflexão é o espaço, entendido como a intersecção, ou meio, onde ocorrem as trocas de informação. O espaço é entendido como a dimensão sem a qual os fenômenos não podem existir.

O estudo etimológico das palavras arte e técnica, revela uma aproximação de significados entre elas pois Techné, em grego, era a palavra utilizada para designar tanto o trabalho de produção de uma cadeira como a produção de uma peça de arte.

Nesse sentido, tanto a arte como a técnica fazem parte do mesmo universo da produção, de transformação da matéria e criação de formas, planejadas e executadas por uma demanda humana e o museu é o equipamento público com papel social e cultural que apresenta estas características.

Este trabalho é uma pesquisa sobre esses museus, caracterizados pelo alto grau de envolvimento com a tecnologia e pela exploração de distintos níveis de interação com o público. 
O objetivo é o embasamento teórico e crítico para a reflexão sobre novos critérios e parâmetros de concepção para os museus contemporâneos que utilizam as TIC's com o conceito de interatividade.

Os resultados foram descritos de forma qualitativa, apoiados por uma discussão teórica sobre as TIC's e aplicados na análise dos edifícios e projetos arquitetônicos selecionados.

\subsubsection{O museu como instituição de interesse público}

O museu é uma das instituições mais representativas da sociedade contemporânea e tem ganhado cada vez mais destaque nas políticas de intervenções urbanas nas principais cidades do mundo. Desde a sua sistematização, no séc. XVII, o museu assumiu um caráter de serviço público e de educação, quando foram criados dentro de universidades e institutos de pesquisa.

O espírito iluminista europeu, posteriormente organizou o museu de maneira lógica, buscando trazer uma ordem e clareza na organização dos objetos que antes eram expostos sem um critério científico e objetivo.

No séc. XIX, as principais nações do mundo inauguraram seus principais museus com o objetivo de afirmar e fortalecer o valor de identidade nacional e dar sentido e legitimidade a uma unidade social, política e cultural.

No séc. XX o museu passou por suas mais profundas mudanças e durante a primeira década do séc. $X X I$ se firmou como objeto de grande interesse em todo o planeta, atraindo investimentos altíssimos e gerando grande dinâmica nas cidades em que se estabelecem.

Com a transformação das formas com que interagimos com a informação e o mundo à nossa volta, a arte naturalmente se interessou por esses fenômenos e 
passou a explorar novos caminhos para refletir e expressar ideias e conceitos acerca do mundo em que vivemos.

Assim, o museu é o vértice onde se encontram a arte, a sociedade e a tecnologia dos novos sistemas de informação e comunicação, formando um espaço de representatividade cultural, onde é representado o conhecimento e tudo aquilo que nos caracteriza como produtores de conhecimento.

Desse modo, o museu permite importantes reflexões para compreendermos as diferentes manifestações da Sociedade do Conhecimento, além de revelar novas formas de integração entre a arte, a arquitetura e as TIC's.

A definição do que é um museu e mais especificamente o que deveria ser um museu do século XXI, é complexa e se configura como uma superposição de significados em constante reavaliação.

Segundo definido pelo Council of Museums (ICOM), conceituado órgão internacional, na sua 20a Assembleia Geral, em 6 de julho de 2001:

"O museu é uma instituição permanente, sem fins lucrativos, a serviço da sociedade e do seu desenvolvimento, aberta ao público e que adquire, conserva, investiga, difunde e expõe os testemunhos materiais do homem e de seu entorno, para educação e deleite da sociedade" (http://icom.museum).

Já o Instituto Brasileiro de Museus, instância museológica máxima no Brasil define:

"Os museus são casas que guardam e apresentam sonhos, sentimentos, pensamentos e intuições que ganham corpo através de imagens, cores, sons e formas. Os museus são pontes, portas e janelas que ligam e desligam mundos, tempos, culturas e pessoas diferentes. Os museus são conceitos e práticas em metamorfose" (www.museus.gov.br).

De acordo com a Política Nacional de Museus, os museus são processos a serviço da sociedade, instâncias fundamentais para o aprimoramento da democracia, da inclusão social, da construção da identidade, do conhecimento e da percepção crítica da realidade. 
O IPHAN, instituto responsável pelo patrimônio histórico e artístico brasileiro,

dá a seguinte definição:

"O museu é uma instituição com personalidade jurídica própria ou vinculada a outra instituição com personalidade jurídica, aberta ao público, a serviço da sociedade e de seu desenvolvimento e que apresenta as seguintes características:

I - o trabalho permanente com o patrimônio cultural, em suas diversas manifestações;

II - a presença de acervos e exposições colocados a serviço da sociedade com o objetivo de propiciar a ampliação do campo de possibilidades de construção identitária, a percepção crítica da realidade, a produção de conhecimentos e oportunidades de lazer;

III - a utilização do patrimônio cultural como recurso educacional, turístico e de inclusão social;

IV - a vocação para a comunicação, a exposição, a documentação, a investigação, a interpretação e a preservação de bens culturais em suas diversas manifestações;

$\mathrm{V}$ - a democratização do acesso, uso e produção de bens culturais para a promoção da dignidade da pessoa humana;

VI - a constituição de espaços democráticos e diversificados de relação e mediação cultural, sejam eles físicos ou virtuais.

Sendo assim, são considerados museus, independentemente de sua denominação, as instituições ou processos museológicos que apresentem as características acima indicadas e cumpram as funções museológicas" (www.portal.iphan.gov.br/portal).

Os textos reforçam o caráter público do museu e seu papel como gerador de identidade cultural, conhecimento, educação e entretenimento. Ele se configura como uma instituição aberta e democrática, que deveria representar a mais alta produção cultural e artística de uma sociedade.

Estes princípios despertam reflexões e auxiliam na identificação de diferentes abordagens sobre o conceito de museu, revelando algumas convergências e divergências entre elas.

\subsubsection{Os museus, as TIC's e a sociedade da informação}

A proposta desta pesquisa foi estudar as transformações dos museus contemporâneos influenciadas pela interatividade oferecida pelos recursos tecnológicos das TIC's (Tecnologias da Informação e Comunicação) e pelos dispositivos e interfaces utilizados na arte e na arquitetura. 
O objetivo é buscar compreender como a arquitetura está se transformando para abrigar essas novas manifestações artísticas, analisando suas consequências conceituais e espaciais e suas formas de comunicação com o público e a cidade.

Além disso, investigar o universo artístico e arquitetônico dos novos museus contemporâneos, realizando uma pesquisa sobre como as novas manifestações artísticas multimídia e interativas estão transformando o espaço dos museus contemporâneos, gerando uma nova dinâmica entre obra e espectador.

No âmbito dessa problemática, a pesquisa toma como estudo de caso museus que se enquadram nesses pré-requisitos, propondo desenvolver uma reflexão que sirva de instrumento para a análise de projetos e propostas para novos museus.

No Brasil, a primeira instituição a trabalhar com arte e tecnologia foi o Itaú Cultural, em São Paulo, que desde 2002 realiza o Festival Emoção Art.ficial de cultura digital, evento que reúne obras e artistas importantes do cenário nacional e internacional.

Em 2006 foi inaugurado o Museu da Língua Portuguesa, junto à Estação da Luz, projeto que incorporou o conceito de interatividade em sua concepção. Esse museu adquiriu importância para a pesquisa por ser um espaço que foi idealizado com o objetivo de explorar as relações de participação do público por meio do uso de sistemas computacionais e obras multimídia.

O Museu do Futebol, aberto em 2008 e localizado sob as arquibancadas do Estádio do Pacaembu, seguiu a mesma estratégia de aproximação do público, tornando os espaços expositivos mais interativos e com conteúdo multimídia.

Os casos citados são interessantes para a pesquisa, pois apresentam abordagens e formas de organização que podem ser comparadas e analisadas 
dentro de um mesmo contexto.

\subsubsection{Arte, tecnologia e interatividade}

A interatividade foi aplicada neste trabalho para traduzir a noção de sistema com que foram analisadas as relações entre arte e espectador. A tecnologia é o meio utilizado pelos artistas para traduzir suas ideias e estabelecer uma comunicação com o público. O envolvimento dos sentidos e a exploração do espaço nas instalações abre novas possibilidades para a aplicação das TIC's e dos sistemas cibernéticos integrados à arquitetura e à cidade.

Para ser produzida, toda arte depende de suportes, dispositivos e recursos, embora um novo meio não leve seus predecessores ao desaparecimento, cada fase da história coloca à disposição do artista materiais, técnicas e recursos que lhe são próprios. Neste início do terceiro milênio, os meios pertencem às tecnologias digitais, presentes nos equipamentos eletrônicos, nos sistemas de informação e comunicação e em praticamente todos os campos de atividades humanas.

Durante os anos 80, havia um tipo de produção artística que iniciava no computador e dele era extraída para ser exibida em meios tradicionais. Gradativamente o computador foi sendo cada vez mais utilizado para estender a capacidade das mídias tradicionais: a fotografia analógica era manipulada digitalmente; o cinema era ampliado no cinema interativo; o vídeo, no videostreaming; o texto ampliado nos fluxos interativos e não-lineares do hipertexto; a imagem, o som e o texto ampliados na navegação interativa da hipermídia em suporte $C D-R O M$ ou em sites via internet; e agora a convergência da TV digital em TV interativa, unindo definitivamente o computador e a televisão.

Na tradição das performances, existem também as performances interativas e 
as teleperformances que, por meio de webcams e sensores, fazem interagir cenários virtuais com corpos presenciais, corpos virtuais com corpos presenciais e outras interações que o artista consiga extrair dos dispositivos tecnológicos.

As instalações multimídia se potencializaram com o uso de vídeos conectados à internet e o uso de webcams que permitem hibridizações entre ambientes físicos e virtuais, normalmente formadas por redes de sensores, câmeras e computadores conectados à internet. Na tradição dos eventos de telecomunicações aparecem, via rede, os eventos de tele-presença e tele-robótica, que permitem visualizar e mesmo atuar em ambientes remotos.

Nos sites ou ambientes criados especificamente para as redes, as variações são múltiplas: sites interativos, colaborativos, sites que integram os sistemas de multi-agentes para a execução de tarefas, que levam o usuário a incorporar avatares dos quais empresta identidades para transitar pelas redes, entre outras. Neste ponto começa a imersão em realidade virtual, quando, nos web sites em VRML (Virtual Reality Modelling Language) o internauta é transportado para ambientes virtuais com interfaces perceptivas e sensoriais.

A realidade virtual pode também se realizar em cavernas digitais de múltiplas projeções. Utilizando softwares complexos com alto poder de processamento, podem ser desenvolvidas novas formas de interface dos dispositivos eletrônicos com o corpo humano, permitindo o diálogo entre os sistemas biológicos e os sistemas artificiais em ambientes virtuais nos quais equipamentos como câmeras e sensores capturam os sinais emitidos pelo corpo para processá-los e devolvê-los como nova informação.

Um dos objetivos dos movimentos artísticos desde a segunda metade do século $\mathrm{XX}$ tem sido levar o usuário a interagir com o trabalho do artista. No 
entanto, fazer dele um co-criador, alguém que compartilha intensamente do ato de perceber, de criar, de tomar decisões e de escolher, são atitudes experimentais que podem ser intensificadas pelo mundo virtual das simulações interativas.

A interatividade enriquece a relação do indivíduo com a máquina, permitindoIhe com ela dialogar. Permite-Ihe também exercitar sua habilidade seletora, sua criatividade, sua capacidade de tomar decisões e de estabelecer relações de significados. As novas condições tecnológicas estão caminhando, cada vez mais, para o desenvolvimento de uma dinâmica perceptiva baseada no desenvolvimento da manipulação de formas, utilizando para isso o conjunto dos sentidos humanos.

\subsection{Definição do objeto e formulação da hipótese}

A partir da confluência dos objetos aqui tratados, o museu, a arte e as TIC's, foi considerado que o espaço arquitetônico onde acontecem os fenômenos é o foco principal e parâmetro para discutir o papel da arquitetura neste campo da produção e consumo cultural na sociedade contemporânea.

Foram estudadas as interfaces entre arte e museu, arte e tecnologia e museu e tecnologia, buscando identificar os principais fenômenos e tendências na interação entre sistemas computacionais e a sociedade em um ambiente artístico e cultural.

Os principais profissionais envolvidos nesta discussão são, principalmente, arquitetos, artistas e curadores, com seus interesses econômicos, políticos e sociais, além da inevitável presença do investidor.

Por outro lado existe o público, ávido por informação e consumo, que interage com o espaço e participa do processo de fruição da arte, vivenciando, trocando 
informações e criando significados em seus processos mentais.

Diante disso, a proposta foi realizar uma investigação com o objetivo de identificar e compreender as variáveis envolvidas na concepção dos museus contemporâneos, que utilizam as novas tecnologias de comunicação para uma interação com as pessoas, oferecendo novas possibilidades para a arte e a arquitetura.

Não se trata apenas da realização de um projeto arquitetônico, mas de toda a estratégia envolvida na conformação de um objeto construído que sintetiza e catalisa o processo de construção de identidade social e cultural. Além disso, a forma de se comunicar com a cidade e a sociedade está se ampliando e revelando diversas potencialidades como serviço cultural, social e educacional.

As cidades contemporâneas são constituídas por uma superposição de redes e sistemas, como as redes de serviços urbanos, de empresas, de organizações não-governamentais e sociais, o que caracteriza aquilo que Terry Winograd descreve como uma tecnologia de groupware (WINOGRAD, 1997).

A cidade se constitui da inter-relação entre diversos sistemas e interfaces que trocam informação constantemente. A arquitetura é um tipo de desenho de interface que possui grande importância na organização da informação. O arquiteto é o profissional mais capacitado para esta função e compreender as transformações técnicas, sociais e culturais é uma prioridade para a produção de espaços que sejam apropriados às nossas necessidades e que expressem uma visão de mundo e uma reflexão coerentes com o nosso tempo.

\subsection{Estratégia metodológica e evolução da pesquisa}

Do ponto de vista metodológico, foi adotada uma estratégia multidisciplinar 
baseada na utilização de conceitos de diferentes campos teóricos, principalmente o artístico, o sociológico, o político-econômico e o cognitivo-comunicativo. Por tratar de uma determinada transformação dos espaços ao longo do tempo, é possível enquadrar o desenvolvimento teórico aplicado aqui na tradição proposta pelo materialismo histórico e dialético.

A hipótese levantada considera que:

A Tecnologia da Informação e Comunicação (TIC's) apropriada pela arte e pela arquitetura pode ser determinante para a criação de museus que sejam capazes de oferecer novas maneiras de interação com a informação e com o ambiente social e construído contemporâneo.

A abordagem desta hipótese se deu por meio das seguintes etapas:

- Primeiro foram abordadas as relações entre a arte e os museus, buscando compreender os diálogos e tensões que ocorrem no espaço do museu e suas transformações;

- Em segundo foi investigado o significado e as relações entre arte e tecnologia, buscando conceituar o aspecto da interatividade e comunicação entre obra e espectador;

- Em terceiro lugar, foi realizado um estudo das configurações de caráter conceitual, formal e técnico da arquitetura dos museus, influenciada pelos fenômenos descritos nas etapas anteriores.

Como complemento ao trabalho, foi enviado um questionário com três questões que foram abordadas na dissertação para dez profissionais da área, mas apenas o Prof. Dr. Cícero Inácio da Silva (pesquisador e professor de arte e comunicação digital, coordenador do Comitê Científico do FILE) colaborou em responder. O questionário completo encontra-se em anexo e a intenção foi trazer a 
opinião de pessoas que lidam com a prática da produção cultural para alimentar a reflexão por meio de diferentes pontos de vista.

No próximo tópico, serão apresentadas as bases conceituais da pesquisa teórica e seus desdobramentos nas análises dos museus.

\subsubsection{Princípios teóricos da estratégia metodológica}

Esta pesquisa se desenvolve em um contexto que considera a convergência entre as tecnologias da informação e comunicação, a telemática e as mídias como base para a Sociedade da Informação. As tecnologias telemáticas estão em todas as atividades produtivas, diluindo as os limites nacionais e territoriais e alterando profundamente as dimensões culturais e sociais do mundo contemporâneo.

Uma das principais chaves para o trabalho é o conceito de cibernética, que contempla o estudo do controle dos sistemas e as interações entre eles. Tanto os sistemas naturais e biológicos, como aqueles mecânicos e artificiais criados pelo homem, podem ser entendidos como parte de uma infinita rede de relações e essa abordagem é importante para uma compreensão mais abrangente do mundo à nossa volta.

Para Wiener (1954), principal teórico e criador da cibernética, a informação é um aspecto quantificável e tão importante quanto a energia ou a matéria na configuração dos sistemas. A premissa para a aplicação da teoria cibernética nos diversos campos do conhecimento é a possibilidade de reduzir todo fenômeno ou processo estudado à geração, transmissão e recebimento de informações.

Os espaços tecnológicos, segundo o que Milton Santos (1997) caracteriza como meio técnico-científico-informacional, têm grande importância na busca pela percepção do espaço contemporâneo. Segundo ele, o espaço é a resultante da 
somatória entre a configuração espacial e as relações sociais que se manifestam sobre ele.

Pode também ser entendido como um conjunto de sistemas de ações e de objetos que depende de relações dialéticas na formação de sua totalidade. Formase então um sistema de objetos que condiciona a maneira como as ações se realizam e também um sistema de ações que caracteriza a criação de novos objetos ou a recaracterização de objetos preexistentes.

Para Santos (1988), o homem vai impondo à natureza suas próprias formas, a que podemos chamar de formas ou objetos culturais, artificiais ou históricos. Estes objetos culturais fazem com que

"(...) a natureza conheça um processo de humanização cada vez maior, ganhando a cada passo elementos que são resultado da cultura. Torna-se cada dia mais culturalizada, mais artificializada, mais humanizada. $\mathrm{O}$ processo de culturalização da natureza torna-se, cada vez mais, o processo de sua tecnificação. As técnicas, mais e mais, vão incorporando-se à natureza e esta fica cada vez mais socializada, pois é, a cada dia mais, o resultado do trabalho de um maior número de pessoas. Partindo de trabalhos individualizados de grupos, hoje todos os indivíduos trabalham conjuntamente, ainda que disso não se apercebam. No processo de desenvolvimento humano, não há uma separação do homem e da natureza. A natureza se socializa e o homem se naturaliza" (SANTOS, 1988, p.89).

O meio técnico-científico-informacional das TIC's (Tecnologias da Informação e Comunicação) contribui para a caracterização dos espaços contemporâneos, na mesma proporção em que traz para o ambiente social a forte presença de elementos da ciência, da tecnologia e da informação (HORAN, 2000).

O que seria o espaço cibernético? O espaço cibernético é o terreno onde está funcionando a humanidade hoje. É um novo espaço de interação humana que já tem uma importância enorme, sobretudo no plano econômico e científico e, certamente, essa importância vai ampliar-se e estender-se a vários outros campos, como por exemplo, na Pedagogia, Estética, Arte e Política (LÉVY, 1996, p. 98).

As novas formas de produção e de organização da sociedade, influenciadas 
pela disseminação maciça das tecnologias de informação e comunicação vêm alterando visivelmente as configurações espaciais urbanas e arquitetônicas das cidades.

Assim como nas esferas do trabalho, da habitação e dos serviços urbanos, nos espaços dedicados à arte e à cultura, nos museus e centros culturais, ocorreram transformações tanto em seus aspectos simbólicos e representativos como em suas estruturas físicas e relações com a cidade e a sociedade.

Segundo Jameson (1979), o que vem acontecendo desde a década de 1960 é uma culturalização das práticas artísticas e de toda a produção de mercadorias, ampliando suas formas de consumo e alimentando a emergência de novos hábitos sociais e comportamentais. Inevitavelmente, a importância e papel social da arte vêm à tona para justificar suas ações.

Ambas as transformações - o museu ativo e integrado ao consumo e a sua relação com a cidade e a sociedade - comportaram uma total mutação tipológica: de organização estática o museu passou a ser um lugar em contínua transformação, com princípios sempre relativos e revisáveis e uma multiplicidade de modelos e formas que têm muito a ver com o caráter poliédrico e multicultural do século XXI (MONTANER, 2003).

Para Lévy (1998), as novas potencialidades que afloram mediadas pela simulação possuem níveis de interatividade que são oferecidos por agenciamentos sócio-técnicos. Interatividade é aqui compreendida como a possibilidade de efetivar trocas que não se limitam à simples aquisição de conhecimentos, ao clicar do mouse ou apertar os comandos do controle remoto, mas à uma atividade que permita a contribuição ativa do sujeito, interferindo no processo com ações e reações, intervindo e criando novos caminhos. 
Negroponte (2000) afirma que as tecnologias digitais de informação e comunicação criam condições para o surgimento de novas mídias em que o modelo massificado de transmissão (poucos falam para muitos) está cedendo lugar a um menos centralizado, em que a rede suporta a comunicação de muitos para muitos. Este sistema fornece possibilidades de interação e trocas sociais, além de alterar diversas práticas de produção colaborativa do conhecimento.

\subsubsection{Matrizes da pesquisa teórica}

Para auxiliar na organização da dissertação e fornecer critérios baseados em uma abordagem multidisciplinar, foram adotados três eixos de análise que perpassam o texto e buscam integrar os capítulos.

\section{a) Matriz cognitiva e comunicativa}

O desenvolvimento de novas mídias e tecnologias pressupõe um redesenho dos espaços e de suas relações internas e externas em praticamente todas as esferas da vida, tanto em casa como no trabalho, no lazer e nos espaços de cultura. As bases para tal transformação estão em constante movimento e novas possibilidades enriquecem o cenário cultural da atualidade.

Uma chave para a reflexão da problemática contemporânea na sociedade da informação está relacionada com o conceito de filosofia do design, desenvolvido por Flusser (2010). Em um ambiente em que a informação é o bem mais precioso, a criação de formas define a maneira de acesso à informação e isso está presente nas interfaces e sistemas que utilizamos todos os dias em nossos computadores, caixas eletrônicos, celulares, etc. O design é entendido como o processo de dar 
forma, ou seja, de in-formar, de revelar, trazer à luz algo que estava oculto.

O conceito de Arte e de Técnica são bastante próximos e analisando a etimologia da palavra grega Techné, encontra-se registros de sua utilização relacionada não somente com o fazer manual, mas também com o fazer das artes superiores e belas artes. A palavra Techné pertence necessariamente à esfera do produzir e da Poiésis, ou seja, é uma forma de produção poética (FLUSSER, 2010).

\section{b) Matriz sociológica}

A tecnologia é um símbolo de desenvolvimento e poder no mundo e desempenha um fator crucial nos meios de produção, influindo no índice de desenvolvimento social o no pleno exercício dos direitos dos cidadãos.

A arte e a tecnologia são manifestações legitimamente humanas e embora possam ser interpretadas diferentemente por uma abordagem funcionalista, ambas trazem em comum o desejo de dominar e transformar a natureza para criar objetos culturalizados.

As TIC's estão sendo incorporadas pela arte para propor uma nova forma de comunicação entre obra e espectador, mais coerente com os fluxos de informação computacional e com interfaces que tragam uma experiência rica em aspectos cognitivos e significativos.

Existem também relações de polarização entre identidades locais e globais e a mercantilização generalizada da cultura, que fabrica produtos culturais sem um lastro social que integre os grupos e gere uma valorização das diferenças (religiosas, étnicas, etc.) em um contexto de globalização.

Unindo a globalização, a fragmentação e a formação de sistemas de nós e interdependências, configura-se a base para o padrão de análise de matriz 
sociológico que será desenvolvido nesta dissertação. A interatividade pressupõem a comunicação e troca de informações em um sistema todos-todos que gere informação e conhecimento para a melhoria da qualidade e supere as desigualdades e injustiças sociais de maneira irrestrita.

Para Lévy (1999) a interatividade aponta para um novo desafio, a necessidade de um trabalho de observação, de concepção e de avaliação dos modos de comunicação em geral, não se limitando, portanto às tecnologias digitais.

O espaço cibernético se encontra também na origem de uma nova arquitetura, de um novo urbanismo. Poderíamos até dizer de uma nova política porque se trata de uma nova pólis que está se constituindo. É assim que pedagogos, artistas, e psicólogos que geralmente não se interessavam por fenômenos técnicos, têm passado a se preocupar com estes problemas (LÉVY, 1993, p.173).

\section{c) Matriz político-econômica}

Os museus são instituições culturais com caráter público, que estão integradas ao sistema político e econômico da produção de capital das principais metrópoles do mundo, movimentando cifras milionárias e diversos interesses em seu processo de construção. Diversos setores estão envolvidos paralelamente, como a indústria da construção, os serviços urbanos, a produção de objetos, entre outros, que participam de um mercado gigantesco de turismo e consumo em espaços culturais e museus do mundo todo.

O papel social de acesso à arte, à cultura e ao conhecimento em geral, se mistura à necessidade de criar um negócio atraente ao investidores e que atenda aos desejos dos políticos e governantes que tomam as decisões e atendem a diferentes interesses. 
Devido ao caráter midiático da sociedade da informação e à culturalização do capital e da mercadoria, a arte às vezes caminha para a produção de objetos de consumo vazios de conteúdo.

$\mathrm{Na}$ sociedade da informação o consumo é potencializado pela fluidez e velocidade com que a mercadoria se transforma e se desloca no espaço, transformando as categorias de experiência do real e do imaterial. Nas últimas três décadas a cultura dos museus foi praticamente reinventada, e com isso a categoria tradicional do espaço da arte como espaço sagrado foi substituída pela experiência e pelo entretenimento com a intenção de envolver o público e produzir mais capital.

Os meios e formas de produção estão atrelados às estruturas de poder e isso afeta a configuração de todas as instituições, inclusive os museus. Em uma análise estruturalista, o esforço é identificar os princípios ordenadores e transformadores que controlam o funcionamento dos sistemas, ao invés de considerar as totalidades como um conjunto de relações causais entre elementos isoláveis. Desse modo, considera-se os sistemas em sua complexidade e interconectividade, buscando compreender os fenômenos por meio das relações e processos envolvidos nos modos de produção.

\subsubsection{O sistema de signos entre arte, museu e tecnologia}

A noção de cultura utilizada aqui, a partir de uma abordagem sociológica e antropológica, é a de um sistema de modos de vida que se sucedem no tempo, transmitidos e compartilhados por membros de um grupo, presente em um determinado local. A arte é uma das formas de expressão e de elaboração de símbolos culturais e o papel das novas tecnologias atualmente é integrar os universos analógicos e digitais. 
A cultura se configura como um conjunto de representações, de práticas sociais, de produção e consumo, de técnicas e de estruturas institucionais e políticas. Todas estas relações fazem parte de um sistema global que gera tensões entre as esferas local-global e produzem trocas culturais mais rápidas.

Neste universo de produção simbólica, a informação necessita de meios para ser distribuída e as interfaces gráficas e as novas mídias se tornaram a matériaprima de trabalho de alguns artistas contemporâneos. Analisando as contribuições sociais da arte, o museu é o espaço institucional próprio para se refletir sobre os sistemas simbólicos da cultura contemporânea.

As TIC's tornaram-se um dos paradigmas da Sociedade da Informação e estão atreladas às relações de poder que determinam as decisões políticas, econômicas e que alteram estruturalmente a cultura contemporânea. Segundo Castells, as novas mídias representam, para essa sociedade, uma língua universal, promotora de integração global e da produção e distribuição de signos culturais (CASTELLS, 2000).

A arte e a arquitetura compartilham um campo em comum quando se pensa no processo de concepção e realização de uma obra. Elas fazem o mesmo caminho que se inicia com uma ideia ou conceito e caminha para a sua materialização segundo determinados procedimentos e etapas. Segundo Flusser (2010), pode-se entender tanto a arte como a técnica (entendido em sua essência, como define Heiddegger) como procedimentos de design.

Os termos design, macchina, tecnica, ars e arte, estão ligados entre si e têm a sua origem em uma visão existencial do mundo. A cultura burguesa moderna fez uma separação entre o mundo das artes e o mundo da técnica e das máquinas, originando uma cisão da cultura em dois campos mutuamente excludentes: o 
científico (duro, quantificável) e o artístico (flexível, qualificativo). A partir do século XIX esta separação passou a não fazer mais sentido e a palavra design passou a ser utilizada como modalidade científica e crítica para representar uma ponte entre a arte e a técnica, direcionando para a criação de uma nova forma de cultura (FLUSSER, 2010).

O design é uma das bases da cultura ocidental e pode ser interpretada como intenção, plano para ludibriar a natureza por meio da técnica, substituir o que é natural pelo que é artificial, construir máquinas que representam o poder de criação, controle e transformação das forças naturais. O design representa o ponto de convergência de grandes ideias derivadas da arte, da ciência e da economia que se elaboraram e enriqueceram em um movimento evolutivo.

O termo design assumiu grande importância na cultura contemporânea e termo usual da indústria, utilizado como forma de diferenciação e agregação de valor. A matéria de que é feito o objeto não é o que confere valor ou utilidade a ele, mas sim a sua forma e o seu design, regidos por uma intencionalidade traçada pelo seu idealizador (artista, arquiteto, projetista, designer, etc.) que lhe confere um valor em si.

\subsubsection{A cibernética como referência teórica}

Os temas tratados foram analisados a partir da identificação das categorias que mais compareciam durante a pesquisa e se tornaram cada vez mais evidentes enquanto parâmetros para o desenvolvimento do trabalho. O que se destaca em primeiro lugar é a interação entre sistemas vivos e sistemas artificiais de modo dinâmico e autônomo na comunicação e criação de significados entre o artista, a obra e o espectador. 
A linguagem do desenho e da imagem é a base tanto da arte como da arquitetura e ferramenta de trabalho para a representação de conceitos abstratos em formas tangíveis. Interagimos com estas formas e signos, formando uma rede de significados que determina as bases de uma cultura. Por serem onipresentes, as TIC's muitas vezes são utilizadas pelas pessoas de forma inconsciente e automática, sem se dar conta de sua importância e potencial transformador. Estes fenômenos são interpretados aqui em suas relações com o espaço desenhado para abrigá-los, em uma perspectiva sobre a cultura e a sociedade que representa.

$\mathrm{Na}$ interação entre os sistemas, estão os usuários, a rede, suas práticas e relações e, na escala ambiental, estão a arquitetura do museu, dos sistemas informacionais e das cidades. O nível de relações e interdependências é complexo e envolvem toda a produção cultural, portanto o desafio deste trabalho é desenvolver um caminho dialético entre arte, museu e tecnologia, identificando tendências na concepção arquitetônica do edifício, assinalando suas contribuições sociais e culturais.

O conceito de controle de sistemas e trocas de informação tratado pela cibernética conforme proposto por Wiener (1954), forneceu instrumentos para o desenvolvimento de pesquisas sobre a complexidade de interações entre homem e máquina.

Em 1970, Wiener já havia desenvolvido boa parte de sua teoria e algumas das aplicações da cibernética já eram realidade, ganhando importância e fornecendo instrumentos para o desenvolvimento da ciência, como aparece no trecho a seguir:

O estudo mais recente dos autômatos, sejam de metal ou de carne e osso, é um ramo da tecnologia da comunicação: suas noções cardeais são as de mensagem, quantidade de distúrbio ou "ruído" - termo tomado da tecnologia telefônica quantidade de informação, técnica de codificação, e assim por diante. 
Numa teoria desse tipo, lidamos com autômatos efetivamente ligados ao mundo exterior, não apenas por seu fluxo de energia, seu metabolismo, mas também por um fluxo de impressões, de mensagens que chegam, e das ações e mensagens que saem. Os órgãos pelos quais as impressões são recebidas são os equivalentes dos órgãos sensoriais animais e humanos. Compreendem as células fotoelétricas e outros receptores de luz; sistemas de radares, que recebem suas próprias ondas curtas hertzianas; registros de potencial de hidrogênio, que podem ser chamados provadores,; termômetros; medidores de pressão de vários tipos; microfones; e assim por diante. Os efetuadores podem ser motores elétricos ou solenóides ou serpentinas de calefação ou outros instrumentos de espécies muito diversas.

Entre o receptor ou órgão sensorial e o efetuador encontram-se conjuntos intermediários de elementos, cuja função é recombinar as impressões entrantes numa forma tal que produza um tipo desejado de respostas nos efetuadores. A informação alimentada neste sistema central de controle conterá muito amiúde informações relativas ao funcionamento dos próprios efetuadores. Entre outras coisas, isso corresponde aos órgãos cinestésicos e outros proprioceptores do sistema humano, pois também temos órgãos que registram a posição de uma junta ou o grau de contração de um músculo, etc. Além do mais, a informação recebida pelo autômato não precisa ser utilizada imediatamente, mas pode ser retardada ou armazenada de modo a tornar-se disponível em algum tempo futuro. É o análogo da memória. Finalmente, durante o funcionamento do autômato, suas próprias regras de operação são suscetíveis de mudanças com base nos dados que atravessaram os seus receptores no passado, e isso não difere do processo de aprendizagem.

As máquinas a que ora nos referimos não constituem o sonho sensacionalista nem a esperança de algum tempo futuro. Elas já existem, como termostatos, sistemas de giroscópios automáticos de pilotagem de navios, mísseis auto propelidos - especialmente os que procuram o seu alvo - , sistemas de controle de fogo antiaéreo, destilarias de petróleo controladas automaticamente, máquinas ultrarrápidas de computação, e similares (Wiener, 1970, p.70-71).

Para Wiener, a inteligibilidade do real está diretamente relacionada à presença configurante e formalizadora de um elemento não-material e nãoenergético - a informação - em todos os influxos recíprocos entre os seres, quer sejam humanos ou não, vivos ou não.

Dessa forma, a informação pode ser compreendida como um elo entre os momentos do fluir dinâmico das coisas, um vínculo que fundamenta a sua visibilidade e a sua inteligibilidade. Discernir entre os diversos estados de um sistema ao longo do tempo é captar uma mensagem, é perceber os efeitos de um 
feedback, fruto das ações do sistema e das reações do ambiente nesse mesmo período, num contínuo processamento da informação.

O papel da realimentação, quer no projeto técnico, quer na biologia, veio a ser firmado. O papel da informação e a técnica de medir e transmitir informação constitui toda uma disciplina para o engenheiro, o fisiologista, o psicólogo e o sociólogo. Os autômatos, que a primeira edição deste livro mal prognosticava, são uma realidade. (Wiener, 1970, p.9)

Além da evidente complexidade dos seus respectivos temas, tais estudos têm em comum o fato de serem requeridos para o tratamento de diversos problemas de controle, tanto de processos artificiais (construídos pelo homem) como de processos naturais (onde o problema já está resolvido, e o interesse é o de descobrir exatamente como foi resolvido).

O controle implica também a existência de um "alvo", de uma "meta", de um "objetivo", ao qual se refiram os possíveis desvios e para o qual se encaminhem os mecanismos de atuação. Quando essa "meta" é simplesmente a manutenção de um estado estacionário, a conservação da integridade do sistema em resposta a perturbações externas, estamos diante daquilo que em fisiologia recebeu o nome de homeostase. Quando, porém, aquilo que se busca manter é um tipo especial de relação com algum objeto ou processo externo ao sistema, estamos diante de uma espécie de corrida de perseguição, de um contínuo fluxo de informações e modificações que nunca alcança uma situação de equilíbrio.

Wiener notou que as mesmas reflexões sobre controle e causalidade circular apareciam tanto em áreas ligadas à Engenharia quanto à Biologia e que este fato estava ligado a importantes questões metodológicas que mereciam aprofundamento. 


\subsubsection{Evolução da pesquisa}

A pesquisa passou por inúmeras transformações e foi se desenvolvendo naturalmente conforme as relações entre os objetos de estudo foram se tornando mais claras. As preocupações em entender a produção do espaço da arte no contexto da sociedade contemporânea com a presença das TIC's despertou a necessidade de estudo das polarizações entre museu e arte, arte e tecnologia e museu e tecnologia.

As disciplinas cursadas auxiliaram na complementação dos temas, principalmente no que foi tratado sobre a cultura pós-moderna e a culturalização do capital em leituras de Jameson. Foram realizadas leituras para trazer referências sobre a formação da sociedade pós-industrial e a evolução da cultura da imagem e da importância do olhar na sociedade da informação.

A pesquisa passou então a buscar a essência dos objetos envolvidos: museu, arte e tecnologia, categorizando e conceituando seus sentidos. Matrizes filosóficas foram utilizadas para traduzir os conceitos e auxiliar no desenvolvimento das análises.

Após a banca de qualificação foi feita uma reestruturação da dissertação, seguindo a sugestão apresentada pelo Prof. Dr. Davi Moreno Sperling, que destacou a importância do espaço enquanto elemento articulador e potencializador das trocas que ocorrem no museu.

Durante a banca, o Prof. Dr. José dos Santos Cabral Filho destacou a importância do desenvolvimento do viés crítico na análise das instituições e textos teóricos que abordam a questão das novas tecnologias, indicando referências bibliográficas importantes para o encaminhamento da pesquisa. 


\subsubsection{Organização da dissertação}

Esta dissertação foi organizada em cinco capítulos principais:

No capítulo 1 - Elementos Teórico-Metodológicos, é realizada uma contextualização da pesquisa, abordando a problemática da produção artística e cultural na sociedade da informação e do conhecimento.

No capítulo 2 - Museu e Arte, são apresentadas algumas das principais características dos espaços museográficos, seguindo uma linha temporal que busca identificar partidos arquitetônicos recorrentes entre os museus e suas relações com a arte e os espectadores.

No capítulo 3 - Arte e Tecnologia, são tratados os aspectos artísticos da utilização das novas tecnologias e sua interação com o público. São apresentados os conceitos de interface e interatividade, com obras que exploram estes conceitos. Será realizado um levantamento das principais instituições de pesquisa, utilizando o trabalho de artistas para exemplificar os critérios estudados.

O capítulo 4 - Museu e Tecnologia, é o desenvolvimento dos capítulos anteriores, onde os conceitos tratados serão aplicados aos museus, observando seus aspectos arquitetônicos, institucionais e museográficos. O capítulo forma um panorama sobre os museus contemporâneos influenciados pelas TIC's e procura identificar recorrências ou padrões de abordagem nos projetos de novos museus. Foram tratados alguns exemplos de museus brasileiros para criar uma contextualização da produção nacional, além de oferecer a possibilidade de uma análise empírica dos objetos estudados.

O último capítulo (capítulo 5) é dedicado às considerações finais, apresentando reflexões sobre a pesquisa e os objetivos alcançados. 
Em anexo encontra-se uma entrevista, concedida pelo Prof. Dr. Cícero Inácio da Silva, em contribuição a este trabalho. As perguntas foram enviadas junto com um resumo da dissertação e uma breve explicação a respeito dos objetivos da entrevista.

\section{Capítulo 2. Museu e Arte}

A trajetória histórica dos museus foi marcada por sua consolidação como instituição pública durante o séc. XIX para um século depois, a partir da década de 1980 até a contemporaneidade, sofrer importantes transformações influenciadas pelas novas tecnologias que ampliaram os horizontes da instituição.

Tais transformações foram, na maior parte das vezes, provocadas pelo choque da arte com o espaço do museu. Os artistas, a partir das vanguardas do início do séc. $X X$, iniciaram um movimento em direção à espacialização das obras de arte que passaram a tensionar o espaço expositivo tradicional dos museus.

A arte e o museu fazem parte de um mesmo sistema e construção de valores, em que a permanência de um depende da existência do outro. Desde a consolidação do espaço do museu como o lugar da arte e da cultura, os artistas começaram a perceber que o espaço não é neutro e que a arte interage direta ou indiretamente com ele.

Durante os anos 1970, uma corrente artística norte americana fundou o termo site-specific art, com o objetivo de produzir obras artísticas que sejam determinadas por questões específicas de um determinado lugar. Os artistas passaram a pensar suas obras para serem expostas em espaços públicos, de modo a construir uma 
forma particular de apreciação e interação. Arte e arquitetura retomaram um eterno diálogo, que valoriza a síntese entre arte e técnica.

Buscando pela etimologia encontra-se que, em sua raiz grega, a palavra técnica é derivada do termo téchné (arte), associada também à palavra tékton (carpinteiro), atividade relacionada à construção. Desta mesma raiz deriva-se a palavra arquitetura, justaposição de arkhé (primeira, principal) e tékton (construção).

O que levanta a seguinte questão: não deveriam os museus serem a expressão máxima da integração da arte e da arquitetura, ao invés de ser apenas uma caixa para estocagem e exposição de objetos.

O artista sempre foi um mestre da técnica, já que por meio dela torna possível transformar a matéria e produzir os objetos imaginados por ele. A palavra arte vem do latim ars, que em grego é traduzida por téchné, o que demonstra mais uma vez o entrelaçamento de significados entre arte e técnica na origem da cultura ocidental.

Seria lógico concluir que arte e arquitetura, neste caso arte e museu, deveriam se complementar e constituir uma unidade em termos de projeto, afinal ambas as manifestações tem como origem uma ideia, um conjunto de intenções, seguido de planejamento e metodologia para conseguir materializar o seu objeto.

Trata-se neste caso da atividade de projeto, no momento em que uma ideia sai do mundo abstrato e se torna concreta, lançando mão do conhecimento extraído da observação da natureza e aplicado no seu controle e transformação.

Talvez faça mais sentido utilizar neste momento a palavra desenho, que em sua etimologia significa intenção, plano, propósito, e que representa o fazer humano e a formação da cultura. Assim, ao desenhar, o homem está concebendo, 
organizando e traçando estratégias com uma finalidade determinada a priori.

Em sua aula de abertura do curso de Desenho Arquitetônico, Artigas (1975, aula proferida) expõe algumas destas analogias entre os termos e esclarece que a raiz da palavra desenho se encontra no termo signum, que quer dizer signo. Daí a derivação para desígnio, que novamente demonstra intencionalidade, intento representado por signos.

Os museus permitem às pessoas conhecer e explorar coleções para a inspiração, aprendizado e entretenimento. Eles são instituições que colecionam, preservam e tornam acessíveis artefatos porque acreditam em seu valor de permanência para a sociedade.

Um fato importante para a constituição dos museus modernos ocorreu com as transformações culturais e políticas do Renascimento, quando uma mudança no conteúdo e forma de organização dos objetos deu origem aos chamados Gabinetes de Curiosidades.

Durante as grandes Explorações e Descobrimentos (séc. XVI e séc. XVII) se colecionava nestes espaços uma multiplicidade de objetos raros e exóticos organizados em três áreas da natureza - animalia, vegetalia e mineralia. Além disso, também eram expostos artefatos da produção humana (artificialia), coleções de plantas e animais exóticos (exótica) e coleções de instrumentos científicos (scientifica) (www.fafich.ufmg.br/ memorandum/a10/janeira01.htm).

Essas coleções provocavam grande fascínio mesmo com sua mistura indisciplinada e pouco organizada, de quadros, conchas, fósseis, insetos, armas, relíquias, estatuetas, aparelhos e pássaros empalhados, que enchiam os olhos e alimentavam a imaginação dos visitantes (figura 1). Essas coleções eram de caráter privado e o público que tinha acesso a elas era restrito às classes mais 
abastadas e à nobreza.

Os gabinetes de curiosidades desapareceram durante os séc. XVIII e XIX e os objetos considerados mais importantes foram transladados para museus de história natural que estavam começando a serem criados.

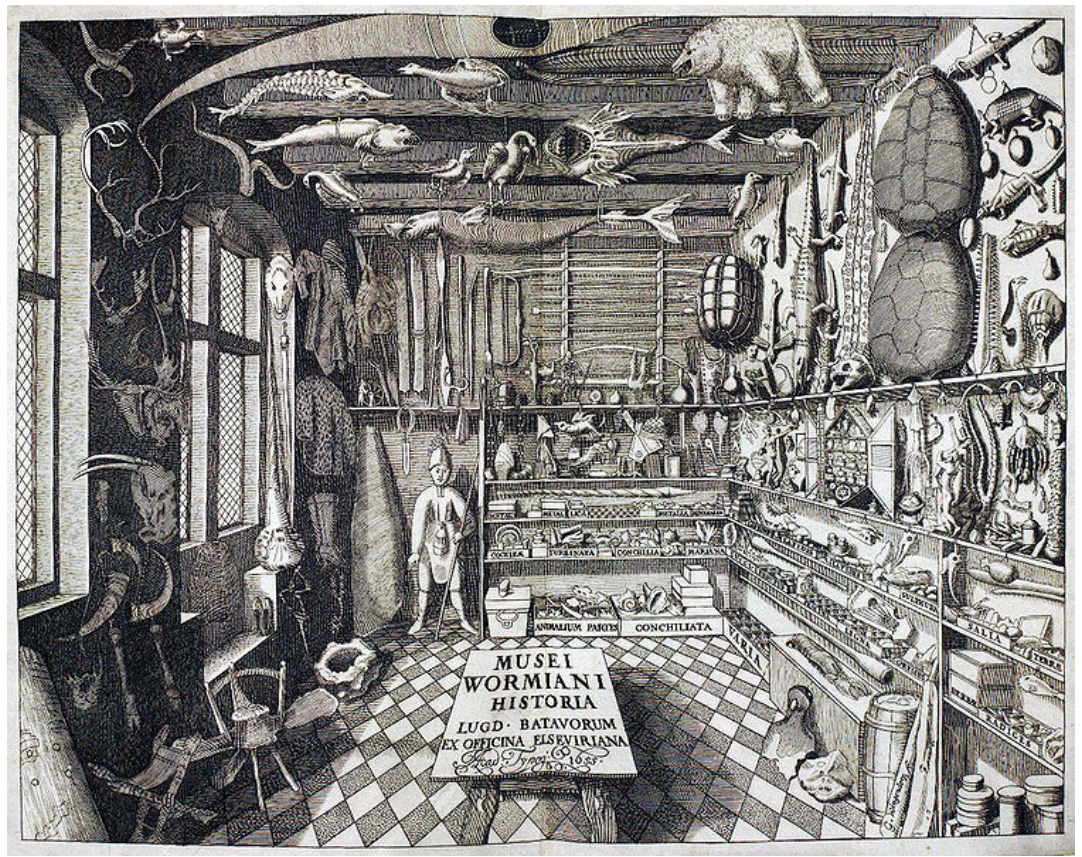

Figura 1. Ilustração de um gabinete de curiosidades, Inglaterra, 1655.

A ideia de museu foi peça importante para a definição de diversos conceitos da arte e da cultura da sociedade ocidental moderna. A partir da segunda metade do séc. XVIII, no período da llustração, foram surgindo as disciplinas da arqueologia e da estética, além do desenvolvimento das técnicas de restauração de obras de arte e monumentos arquitetônicos.

A cultura dos países europeus se desenvolveu em estreita relação com os museus, que contribuíram decisivamente para a formulação de novas teorias estéticas.

O museu surgiu de coleções públicas e privadas e esteve relacionado 
historicamente com a criação dos Estados Modernos. Neste aspecto, a Revolução Francesa contribuiu em grande parte ao Ihe atribuir sua devida importância enquanto serviço público, papel por ele desempenhado ao longo de todo o séc. XIX, na Europa. Durante esse período o museu foi sendo moldado segundo as ideologias nacionais de cada país, se caracterizando cada vez mais como um serviço público prestado pelo Estado, com funções culturais e educacionais.

Grandes historiadores passaram a trabalhar como curadores de importantes museus, se dedicando ao estudo das obras e estabelecendo critérios de apresentação para as coleções.

Em seu ensaio Of other spaces, Foulcault (1967) define heterotopias como espaços reais onde ocorre a justaposição de lugares e espaços incompatíveis entre si. Isso acontece no retângulo do palco de um teatro, onde se representam diferentes tempos e lugares, ou na sala de cinema, onde são representados espaços diferentes e distantes na tela de projeção. São espaços que normalmente estão ligados à fatias de tempos diferentes que pressupõem uma quebra com o sentido tradicional do tempo.

A ideia de acumular objetos, de estabelecer uma espécie de arquivo geral que reúna em um só lugar todos os tempos, todas as épocas, todas as formas, todos os gostos, o projeto de organizar nele um tipo de acumulação infinita e perpétua do tempo em um espaço imóvel, pertence à nossa modernidade. Desse modo, ele argumenta que o museu e a biblioteca, ambos heterotopias da acumulação indefinida do tempo, são peculiares e característicos da cultura ocidental do séc. $\mathrm{XX}$.

A partir do séc. XIX surgiu o desejo de criar um novo espaço cultural para o público moderno, idealizado como o espaço de representação da ciência e da 
razão, assumindo um papel didático e educativo.

Em parte, essa foi uma forma de distinguir o museu moderno de seus predecessores, para destacar a ordem e racionalidade da confusa incongruência que caracterizava os antigos salões de curiosidades.

Este caminho que levou o museu do caos para a ordem foi, simultaneamente, o que superou o domínio das crenças e mitos pela verdade comprovada pelos métodos da ciência. Os princípios de especialização e classificação são o que distinguem o museu moderno, levando ao desdobramento de uma variedade de tipos especializados de museus (de geologia, de história natural, de arte, etc.) em que cada um dos objetos está arranjado de modo planejado a fim de criar uma narrativa, uma leitura científica e inteligível do mundo.

Os museus pré-modernos buscavam criar surpresas ou provocar o deslumbramento no público, o que atraía o foco para o raro e excepcional, pelo interesse no que há de singular nos objetos e não pelas suas características típicas, traduzindo os princípios de exposição pela procura do sensacional ao invés de produzir um efeito pedagógico por meio da disposição racional dos objetos.

Paul Valéry, no texto O problema dos museus (1993), relata uma visita a um museu, em que se vê cercado pelo tumulto de criaturas congeladas, subjugado por um horror sagrado ao ver as pinturas dispostas sobre as paredes. Valéry conclui que só uma civilização pouco razoável pode ter construído um espaço de tamanha incoerência, criticando o efeito atemporal e mortuário que o museu adquiriu.

Theodor Adorno e Walter Benjamin também produziram ensaios que contribuíram para o reconhecimento do complexo mundo dos museus. Em "Museu Valéry-Proust" (1967), Adorno analisa a questão do museu através das opiniões de Valéry e Proust e estabelece um diálogo entre elas. 
Benjamin, em seu ensaio sobre "Os Espaços que Suscitam Sonhos" (2005), trafega por vários estilos arquitetônicos, por pavilhões de exposições industriais e de águas medicinais, por galerias de arte e pelos esgotos de Paris, além dos museus: "neles, teria de se sublinhar a dialética com que vêm ao encontro da pesquisa científica, de um lado, e da época sonhadora de mau gosto, de outro".

Ao analisarmos o museu devemos sempre ter em mente o contexto em que foi concebido, para entendermos a visão que se tinha sobre a arte e seu espaço de representação máxima.

Em meados da década de 1970, Brian O'Doherty, um artista plástico e escritor americano escreveu uma série de quatro artigos publicados na revista Artforum que se tornaram referência clássica para a análise crítica do espaço do museu. Reunidos posteriormente em livro, esses artigos fornecem substrato teórico para a compreensão do museu moderno por meio da visão de um artista inserido em seu meio.

Em uma análise das ideologias que permeavam cada momento histórico, ele percorre a história da pintura desde meados do séc. XIX, revelando como a visão de mundo de cada período influenciou na criação e definição dos conceitos envolvidos na organização do espaço dedicado à arte. Dessa forma é estabelecida uma sistematização do espaço do museu, que atende a regras e interesses que evoluem historicamente.

Analisando sua estrutura e conteúdo ideológico, é possível rever os preceitos e premissas relacionados ao espaço de exposições. Os artistas, a partir do momento em que tomam consciência da relação que a pintura tem com o espaço e as obras que a rodeiam, abrem a possibilidade de uma revisão de seu próprio sistema estético. 
Durante o séc. $\mathrm{XX}$, formulou-se uma matriz conceitual que pairou sobre grande parte da produção de arte desse período, determinada pela noção de arte instaurada pelo Museu de Arte Moderna de Nova lorque (MoMA), na primeira metade do século passado.

Seu caráter asséptico e atemporal fez com que a obra de arte fosse individualizada e apresentada em um espaço homogeneizado que apaga as sutilezas arquitetônicas do edifício. A obra adquire autonomia e vida própria, estabelecendo relações espaciais com as outras obras presentes e revelando a importância de um arranjo espacial equilibrado.

Essa análise tem especial interesse porque quem a realiza é alguém especializado na produção e percepção desse espaço: o próprio artista. Além disso, por se tratar de um texto não propriamente acadêmico, lança mão de uma flexibilidade estrutural, metodológica e teórica que se aproxima de uma visão poética.

A arte moderna esteve diretamente relacionada à elaboração das condições espaciais dos museus. Esse espaço normativo produzido pelos modernistas foi chamado por O'Doherty de "Cubo Branco" (1976). Da mesma forma que a arte do séc. XX realizou uma tomada de consciência metalinguística que desvelou 0 caráter ilusório da representação espacial pictórica e destacou seu suporte físico (a tela), o objetivo é deixar claro que o museu utiliza determinadas estratégias e recursos para criar os efeitos desejados no espectador.

O museu modernista foi deliberadamente concebido como um espaço introspectivo e auto-referente, que produz um ambiente sacralizado, atemporal e apartado da realidade externa do mundo.

Um dos princípios fundamentais dos espaços sacros é impedir a invasão do 
mundo exterior, o que explica o fechamento permanente de suas aberturas. Com isso pode-se alcançar uma temporalidade abstrata, distante do tempo da vida cotidiana. Inserido nessa atmosfera extemporânea, ou atemporal, a obra de arte se apresenta como algo já incorporado à posteridade.

Curiosamente esse tipo de espaço é recorrente em diversas culturas, aplicado sob a ótica da religião, que se utiliza dessa "câmara eterna" para apartar-se do mundo exterior e possibilitar o acesso à eternidade.

Essa busca por um espaço transcendental, que realize o contato com a eternidade, pode ser percebida desde a arte rupestre do Paleolítico, onde as pinturas e esculturas se encontravam nas cavernas, espaços isolados e de difícil acesso.

Esses espaços eram portais de comunicação entre o céu e a terra, manipulados e concebidos conforme as intenções do grupo a que estava ligado. Esse espaço tem o poder de anular simbolicamente a matriz convencional do tempo e instaurar uma relação cósmica com espaços e tempos míticos.

Fica evidente que esses propósitos derivaram dos interesses políticos das classes ou grupos governantes, que ao mesmo tempo em que respondiam à busca humana pelos símbolos sagrados, possibilitavam a manutenção de seu poder por meio do acesso à eternidade.

O que ocorre nos espaços de exposição é a busca pela posteridade artística, pela beleza imutável, imortal, presente na obra-prima. No entanto devemos perceber que há sempre um sujeito e uma escolha por trás de determinada forma de sensibilidade ou juízo estético.

O espaço do museu abriga um conjunto de relações traçadas entre o artista, a obra de arte e o espectador. Para a melhor compreensão dessas relações é 
necessário investigar o contexto do surgimento desse sujeito sem rosto que é o espectador.

No momento em que estamos diante de uma obra de arte, há uma dissolução de nossa individualidade em favor do "Olho" e do "Espectador". Nosso "Olho", representa a capacidade de nos desligarmos momentaneamente de nosso corpo para assumirmos uma existência exclusivamente ligada aos meios visuais formais.

Sem sombras, branco, limpo, artificial - o recinto é consagrado à tecnologia da estética. Montam-se, penduram-se, espalham-se obras de arte para estudo. Suas superfícies imaculadas são intocadas pelo tempo e suas vicissitudes. [...] A arte existe numa espécie de eternidade de exposição, [...] não existe o tempo.. Essa eternidade dá à galeria a condição de limbo; é preciso ter morrido para estar lá. (O’DOHERTY, 2002).

A evolução do museu pode ser analisada a partir de um entendimento das transformações da própria pintura e de seus meios de representação. A pintura de cavalete de meados do séc. XIX teve uma relação direta com suas formas de organização e disposição nas galerias de arte.

A partir daí pode-se seguir o caminho da arte a partir de sua relação com seu suporte físico e campo sintático. Foi somente com a conscientização da tela enquanto suporte para construção de um simulacro que o artista conseguiu partir para a ruptura com os paradigmas da pintura acadêmica.

O cubo branco (O'DOHERTY, 1976) foi considerado um instrumento de transição utilizado pelo modernismo para se desvencilhar do passado e dominar o futuro, utilizando métodos transcendentais de presença e poder. Ele tem a finalidade de dar acesso a esse outro mundo, platônico, idealizado. A estética aplicada a esses espaços atribuiu destacada importância aos princípios platônicos de idealização da forma, demonstrando grande apreço pela abstração eterna da matemática e pela ideia da forma pura e objetiva. 
O objetivo do cubo branco é alcançar essa transcendência, apagando a vida e assumindo formas com fins específicos determinados socialmente, ele representa o mito da eternidade e da transcendência, o que pode ser caracterizado como uma tendência dominante, embora existam outras, como a visão dada pelo ethos socialista, baseada numa visão contextual e imersa no universo do trabalho, que rompem com a visão platônica e autonomista da estética.

A história da arte moderna pode ser relacionada com as mudanças no espaço do museu e na maneira como o vemos, a ponto do espaço se tornar o grande protagonista, alcançando o status de obra de arte. Dessa forma o próprio museu ganha importância como polo de atração e veicula sua imagem como expressão artística em forma de arquitetura.

A história do modernismo é enquadrada por esse espaço intimamente; ou melhor, a história da arte moderna pode ser correlacionada com as mudanças nesse espaço e na maneira como o vemos. Chegamos a um ponto em que primeiro vemos não a arte, mas o espaço, em si. [...] Vem à mente a imagem de um espaço branco ideal que, mais do que qualquer quadro isolado, pode constituir o arquétipo da arte do século XX; ele se clarifica por meio de um processo de inevitabilidade histórica comumente vinculado à arte que contém (O’DOHERTY, 2002).

Os artistas contribuíram muito para a ocupação do espaço tridimensional do museu, ao romperem com o espaço bidimensional da tela em busca de experiências sensoriais e novas interpretações do espaço a partir das instalações.

A evolução dos meios utilizados pelo artista e a busca por uma apropriação do espaço, investigando suas estruturas e propondo um maior envolvimento do público, leva à uma revolução nos espaços culturais.

A própria tela se desmaterializa, e a parede do museu se torna uma tela de projeção, emanando luz ao invés de recebê-la, como nos museus tradicionais. O controle da iluminação é essencial para que seja possível apresentar obras que por 
si já irradiam a luz para o ambiente.

A relação da tela ou superfície da pintura com a parede que está por trás e lhe dá suporte passa por diversas interpretações, até o momento em que a própria tela é rompida, revelando sua materialidade e criando um diálogo com a superfície da parede.

A tradição de pintura de murais dá lugar ao quadro pendurado na parede, a parede pintada é substituída por um pedaço de parede portátil. A força da moldura delimita o quadro, onde a miniaturização da pintura auxilia ainda mais seu efeito ilusório. A pintura torna-se uma janela móvel que abre espaço na parede, criando uma abertura para outro mundo.

A comparação metafórica com a janela é vista em diversos quadros da arte ocidental, em que uma janela dentro de um quadro emoldura não só uma paisagem distante, como confirma os limites da moldura. O tamanho diminuto de algumas telas reforça ainda mais o espanto pela grande dimensão espacial que representam e pela perfeição dos mínimos detalhes encontrados.

Quanto maior o efeito ilusório, maior a atenção atraída para o olho do espectador. O olho é abstraído do corpo e mergulha para dentro do quadro, como um pequeno avatar, para percorrer e vivenciar o espaço ali representado.

O que torna isso possível é a presença da moldura. Essa delimitação da área de observação dá a segurança necessária para que a atenção concentre-se em seu interior. A estabilidade da moldura cria o distanciamento necessário para que haja uma quebra de continuidade entre o espaço da pintura e o que lhe circunda.

A partir de meados do séc. XIX, ocorre uma pressão interna sobre o limite rígido da moldura. A pintura expande a sua espacialidade e torna-se uma superfície imprecisa, apresentando uma tensão entre a profundidade infinita e o achatamento 
da superfície pictórica. A paisagem delineada pela linha do horizonte torna-se tema recorrente, atravessando com mais facilidade o limite determinado pela moldura.

No séc. XIX o tema era o centro da análise, enquanto durante o séc. XX a atenção se deslocou para os seus limites e definição, o que reflete uma diferente concepção e visão de mundo. A análise dos limites estabelecidos pelo campo de estudo torna-se mais importante que o estudo do objeto, apresentando uma atitude típica do séc. $X X$.

Foi com o impressionismo que se deu uma das mais importantes transformações no que diz respeito à materialidade da obra, no modo de pendurar o quadro e no próprio recinto de exposições. Com a ideia do achatamento da pintura e o desenvolvimento de um espaço autônomo de formas e cores próprias, que abandona a ilusão de espaço e formas "reais", o espaço da tela pressiona ainda mais a moldura, levando à sua dissolução.

Em 1890 ocorre a primeira afirmação sobre o achatamento da tela, o que demonstra o reconhecimento da pintura enquanto objeto ou superfície recoberta por tinta, linhas e cores. Tal conceito foi brilhantemente representado por Magritte em seu quadro Ceci n'est pas une Pipe (1929), em que o artista desvincula o objeto artístico daquilo que ele representa.

A superfície pictórica torna-se um tema bastante rico para ser explorado. Novos valores dão lugar aos padrões anteriores da pintura, como suas hierarquias de composição, criação de ilusão e outras regras outorgadas pela tradição acadêmica. A obra torna-se autossuficiente, lançando um debate sobre a integridade da superfície pictórica, a uniformização do espaço e a pureza da forma.

Um dos aspectos relevantes para esta pesquisa é estudar o caminho que a arte percorreu para incorporar o espaço como instrumento de reflexão estética e a 
interação entre obra e público como estratégia de fruição artística.

Esses conceitos iniciam suas primeiras formulações no início do século XX e continuam sendo utilizados até hoje, principalmente na forma de instalações.

Essas características serão exploradas pela arte eletrônica, que a partir da cibernética, dos conceitos de feedback e inteligência artificial e das TIC's, criam uma nova forma de interação entre arte e espectador.

As paredes, onde se dispunham as telas, agora possuem outro significado, recebem projeções de imagens em movimento, se desmaterializam e nos transportam para outros espaços. O som é incorporado como elemento artístico e a possibilidade de comunicação pelas redes aumenta o potencial de trocas de informação e alcance.

Foi no início do séc. XX, com o impacto causado pelas vanguardas artísticas, que o museu sofreu suas mais ácidas críticas, provocando uma reflexão que transformou os conceitos de museu enquanto instituição e espaço de colecionismo.

Fillippo Marinetti, no Manifesto Futurista de 1909, chamou os museus e bibliotecas de "cemitérios" e exigiu que fossem destruídos; Jean Cocteau qualificou o Louvre como "depósito de cadáveres".

A classe artística se opunha à ideia de um museu estagnado no tempo, que abriga objetos de um tempo histórico que buscavam romper, conquistando novos significados para a arte.

Inserido neste panorama de revisão crítica do papel da arte, para garantir a sua sobrevivência, o museu teve que responder às provocações para não cair na obsolescência. O feroz ataque das vanguardas modernas foi crucial para isso, embora pouquíssimos museus tenham sido projetados pelos arquitetos que faziam parte das vanguardas. 
No período pós Segunda Guerra, Duchamp realizou algumas instalações que expuseram visceralmente o espaço do museu, apresentando uma nova forma de interpretação do significado desse espaço. Na obra Twelve Hundred Coal Bags Suspended from the Ceiling over a Stove (Figura 2), o artista direciona o olhar do público para o teto ao invés das paredes, criando tensão e deslocando o plano de observação tradicional das obras de arte.

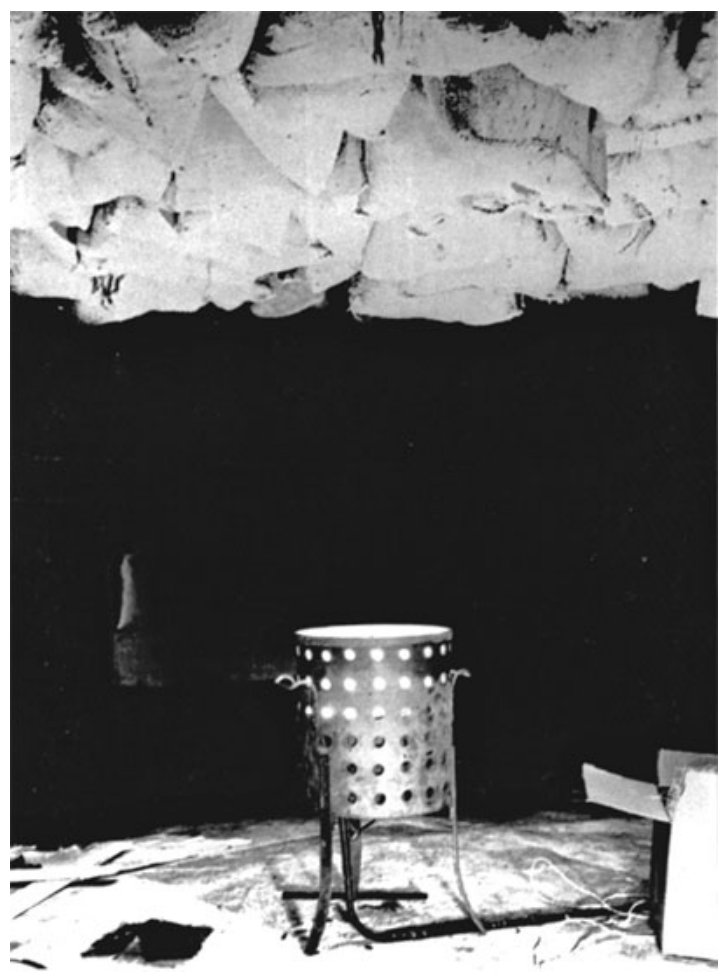

Figura 2. Marcel Duchamp, Twelve Hundred Coal Bags Suspended from the Ceiling over a Stove, 1938.

Outra obra importante sobre este mesmo aspecto foi chamada A Mile of String (Figura 3), em que Duchamp atravessa o espaço da galeria de exposições com fios, revelando sua estrutura espacial e demonstrando como a arte pode dialogar com o espaço, se deslocando da superfície da tela para o espaço dinâmico da galeria. 


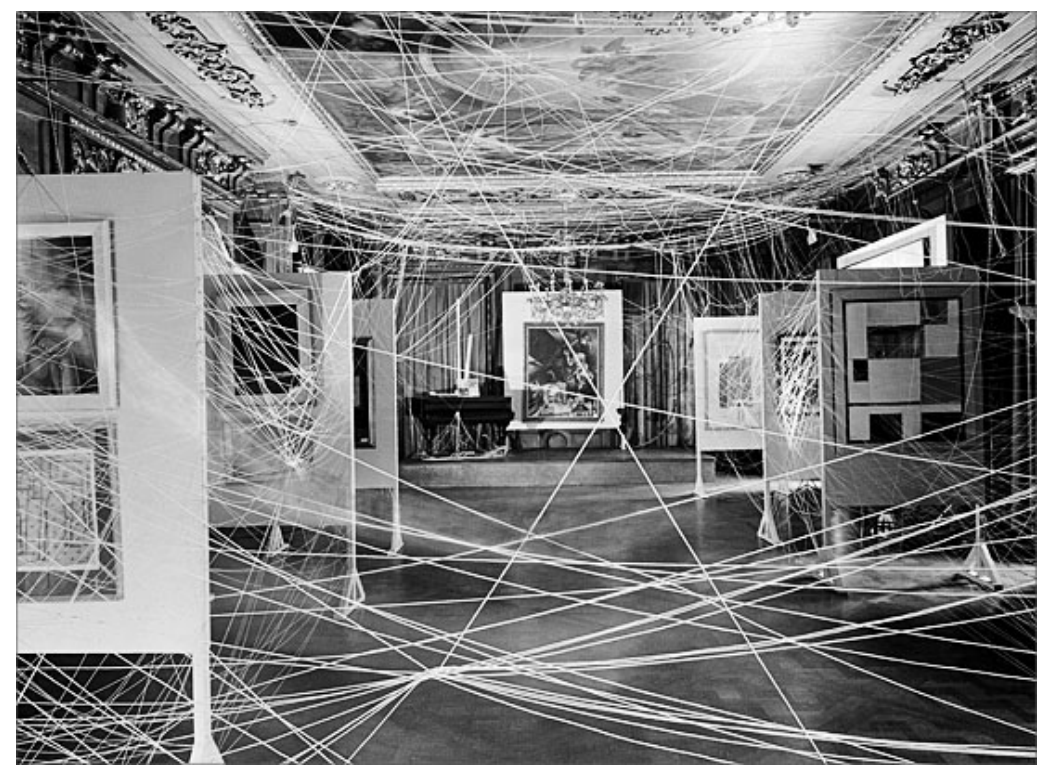

Figura 3. Marcel Duchamp, A Mile of String, 1942. Instalação em forma de teia de fios, apresentada durante a Exposição Retrospectiva de Arte Surrealista, em Nova lorque.

Ao expor o efeito do contexto na arte, do continente no conteúdo, Duchamp percebeu uma área da arte que ainda não havia sido inventada. Essa invenção do contexto deu início a uma série de intervenções que "desenvolvem" a ideia do recinto da galeria como uma peça única, boa para ser manipulada como um balcão de estética. Desse momento em diante, há um vazamento de energia da arte para o que a rodeia. Com o tempo, a relação entre a literalização da arte e a mitificação da galeria cresce inversamente (Idem, Ibidem, 2002, p. 75-76).

A partir da tomada de consciência do suporte artístico enquanto meio de expressão e reflexão sobre a própria arte, houve um deslocamento gradativo do espaço pictórico construído sobre as relações de perspectiva para uma abstração do espaço e uma reflexão sobre os meios e técnicas utilizados pelo artista.

O novo espaço, não mais confinado a uma zona ao redor da obra e agora imbuído da memória da arte, pressionou suavemente a caixa que o enclausurava. Gradativamente, a galeria impregnou-se de consciência. As paredes tornaram-se chão; o chão, um pedestal; os cantos, vórtices; o teto, um céu estático. O cubo branco tornou-se arte potencial; seu espaço fechado, um meio alquímico. Arte passou a ser o que era colocado lá dentro, retirado e reposto regularmente. Será que a galeria vazia, agora repleta daquele espaço flexível que podemos relacionar com a Mente, é a maior invenção do modernismo? (O’DOHERTY, 2002, p. 101)

O museu assumiu diversos significados conforme as intenções e escolhas 
é uma instituição típica da modernidade e representa um serviço prestado à sociedade, de caráter público, que tem o papel de auxiliar o desenvolvimento e a disseminação cultural de um determinado grupo social.

Suas atividades se ampliaram bastante e consistem, entre outras atividades, adquirir, conservar, pesquisar, comunicar e exibir objetos ou bens materiais e imateriais produzidos pelo homem e pela natureza com o propósito de proporcionar educação, pesquisa e entretenimento, como define o Conselho Internacional de Museus (www.icom.org.br).

A instituição Museu é hoje um caleidoscópio de possibilidades: à medida que os museus se especializaram por áreas de conhecimento, as instituições foram repensando e reintegrando funções.

No decorrer do século $X X$, se organizaram por períodos históricos, se tornaram públicos e, posteriormente, de novo, privados, se criaram centros de exposição sem coleções, ou centros de criação com exposição, se repensaram critérios de coleção e conservação, se identificaram estratégias de afirmação de cidades através da cultura e se articularam em redes internacionais, se afirmando muito mais agora pela sua programação do que pelas suas coleções ou peças do acervo permanente.

De edifícios sem coleção, a programações de grande prestígio sem mesmo possuir edifício próprio, encontra-se hoje uma pluralidade e diversidade de museus e instituições culturais cada vez mais híbridas, dividindo o protagonismo das grandes coleções do mundo Ocidental com as novas coleções que surgem na Ásia e no Oriente Médio.

Foi apenas no final dos anos trinta e início dos quarenta, que o museu assumiu uma postura mais consolidada e cristalizou algumas formas significativas 
de organização espacial.

A polêmica crítica institucional no campo da arte foi retomada e a partir dela alguns museus estão repensando seu papel como instituições, com perfil cultural, social e educacional. Torna-se cada vez mais importante a colaboração entre organizações externas e artistas convidados para a produção e alojamento de novos projetos, ampliando a capacidade de intervenção e sustentabilidade das instituições públicas.

Desta problemática surgem experiências de modelos institucionais mais ágeis e flexíveis, em que o objeto preservado perde centralidade e é substituído pelo debate e a reflexão como estratégia de renovação.

Hoje, a construção de Museus é um dos programas mais atrativos para os arquitetos e é uma grande oportunidade autoral para os que os desenham: aliados a estratégias de marketing imobiliário das administrações municipais, estes edifícios exploram plasticamente morfologias e criam imagens fortes que se oferecem para a midiatização das cidades, das instituições, dos colecionadores e, em alguns casos, dos mecenas que os geram e financiam.

Os museus contemporâneos foram fortemente influenciados pela sua ampliação e transformação a partir dos anos oitenta, quando se consolidou a cultura pós-moderna do ócio e da indústria cultural.

O aumento significativo do público criou a necessidade de ampliar os serviços do museu, que aumentou a oferta de exposições temporárias e locais para consumo, demandando o aumento das áreas de administração, educação e conservação.

Muitos dos museus contemporâneos seguiram a linha dos protótipos da arquitetura moderna, manifestando alguns valores das tipologias dos museus 
históricos e aplicando novos conceitos à sua concepção convencional.

Após a Segunda Guerra, os museus europeus passaram por uma fase sem grande mudanças, permanecendo até o final dos anos cinqüenta nos mesmos moldes criados até então.

Segundo Montaner (2003), pode-se identificar quatro paradigmas de museus a partir desse período:

1. O modelo de museu de crescimento ilimitado, definido em 1939 por Le Corbusier como uma forma retilínea que se entrelaça;

2. A ideia do museu como uma pequena povoação (1942), projetado por Mies Van der Rohe como um platônico museu de planta livre;

3. O Museu Guggenheim de Nova Iorque (1943-1959), criado por Frank Lloyd Wright que explora a forma orgânica e singular gerada por seu percurso helicoidal;

4. E a formulação de Marcel Duchamp de total dissolução do museu, com seus objects trouvés surrealistas e com sua proposta de um minúsculo museu portátil, a Boite em Valise (1936-1941), que abriu novas perspectivas conceituais para as exposições e para os museus.

Com o esforço nacional concentrado na construção de moradias e infraestrutura para as cidades devastadas pela guerra, as novas iniciativas de concepção na criação de novos museus passa a acontecer em território norteamericano. A Europa irá dedicar-se à construção de novos museus apenas no começo dos anos oitenta, quando inicia-se a criação de uma nova geração de museus.

A partir dos anos oitenta, uma grande quantidade de museus foi construída, com diferentes propostas surgindo como consequência desse despertar de novos 
projetos. No entanto, se realizado um estudo mais atento, pode-se identificar algumas características comuns e recorrentes em meio a essa multiplicidade.

Por meio de uma análise arquitetônica sistematizada, Montaner (2003) aponta para uma série não muito extensa de opções projetuais para atender às necessidades programáticas da complexidade funcional e representativa do museu contemporâneo. Adotando distintas posturas de projeto e repertórios formais, os museus proliferam pelas cidades, surgindo tanto na forma de novas edificações como na de intervenções em edifícios existentes.

Os projetos variam quanto à sua organização espacial, seus critérios museográficos, suas formas de apresentação das coleções, suas manifestações de valor simbólico, suas relações com o contexto urbano e a paisagem em que se inserem, além das opções técnicas e construtivas relativas aos materiais e técnicas empregadas na construção. Em alguns projetos a forma externa do edifício busca não somente resolver o programa funcional, mas também expressar o conteúdo que abriga o museu e expressar seu caráter público e cultural.

Acompanhado disso veio também a integração do consumo no espaço dos museus, que recebeu cafeterias, restaurantes, lojas, livrarias, etc.

Em suas relações com o entorno e a cidade, o museu reforçou seu caráter público e coletivo, se tornando um espaço representativo e característico da cidade contemporânea.

Este resultado não pode ser analisado sem compreender a importância de algumas propostas das vanguardas artísticas do começo do séc. $\mathrm{XX}$ e de alguns museus dos anos de 1950, que contribuíram para a linha evolutiva dos museus e espaços culturais, destacando-se as suas maiores transformações, ocorridas nos últimos trinta anos. 
É importante destacar uma característica observada por Montaner (2003, p.148) que descreve um fenômeno contemporâneo de aproximação entre os espaços museográficos e os espaços de consumo. É curioso notar como, mais especificamente no museu em forma de contêiner, eles adotam estratégias comumente encontradas em espaços de consumo, que utilizam a aplicação de estímulos aos sentidos e iluminação cênica para atrair a atenção das pessoas.

Em contrapartida, as lojas comerciais adotaram estratégias de exposição que buscam agregar valor aos seus produtos, elevando-os à categoria de objetos artísticos. Sapatos, roupas ou automóveis, objetos produzidos pela estandardização da indústria, são expostos como objetos únicos e irrepetíveis, uma edição limitada de uma obra de arte. Seguindo essa lógica, muitas lojas de marcas famosas passaram a ser concebidas por grande arquitetos, como Rem Koolhas, que assume deliberadamente utilizar a lógica de fruição espacial dos museus para prender a atenção do público, o que garante uma aproximação maior e apelo estético do objeto.

Em outro sentido, os museus de caráter mais social e coletivo, geram grandes espaços urbanos, como os itinerários de pedestres da ampliação da Staatsgalerie em Stuttgart, de James Stirling, o parque escalonado do Museu Municipal de Mönchengladbach, de Hans Hollein, a praça dels Àngels, junto ao MACBA, de Richard Meier, em Barcelona, o passeio às margens do canal junto ao Museu Guggenheim em Bilbao, de Frank Gehry, ou o vestíbulo da Tate Modern em Londres, de Herzog e De Meuron.

O Museu veio, juntamente com a evolução cultural dos países, assumir o papel de conferir urbanidade, representatividade e vida coletiva às metrópoles contemporâneas. 
Os museus e suas coleções converteram-se em espaços de atração de grande público, de importância turística e elemento de agregação dos cidadãos de uma cidade, oferecendo cultura e entretenimento. Por isso, têm sido um dos programas mais utilizados pelas cidades contemporâneas para atrair pessoas, investimentos e gerar uma forma de marketing cultural para auxiliar na veiculação de imagens que sejam associadas à uma cidade ou território.

No entanto, existem edifícios e projetos de arquitetura, que muitas vezes não se relacionam com as especificidades físicas, geográficas e culturais do lugar, priorizando aspectos mercadológicos e financeiros.

Eles se configuram como espaços autônomos e auto-referenciados (MUÑOZ, 2008), como pode-se observar nos centros comerciais, nos museus metropolitanos, nos parques temáticos e nos aeroportos, onde a área destinada ao consumo é cada vez maior.

Além da incorporação dos espaços para compras, estes equipamentos adquiriram abrangência regional e em alguns casos internacional, organizando fluxos e se conformando como polos autônomos, que influenciam a organização territorial.

Segundo Muñoz (2008), este tipo de urbanismo, organizado espacialmente por edifícios autônomos, gera um tipo de geografia urbana formada por objetos que demonstra a relevância dos fluxos de pessoas e informação como elemento substancial do território.

Esta organização polarizada, geradora e organizadora de fluxos, caracterizada pela conteinerização e objetificação da paisagem urbana, foi conceituada como (hub)banismo, uma fusão das palavras hub (um equipamento para redes de dados que organiza e gerencia os fluxos de informações entre 
sistemas computacionais) com urbanismo, que demonstra um novo entendimento da organização e dinâmica que acontece nas metrópoles contemporâneas.

Esta lógica de organização urbana teve início com a configuração dos primeiros hipermercados, que surgiram na paisagem norte-americana ao mesmo tempo em que as grandes autoestradas (highways) e os enormes parques de estacionamento.

Estes espaços de consumo produzem uma outra realidade, ou hiperrealidade, tornando-se uma simulação de uma "realidade", que agrega uma simultaneidade de funções, sem passado e sem futuro, uma operacionalidade em todas as direções (BAUDRILLARD, 1979).

A consequência disso seria uma indeterminação das funções e desintegração da própria cidade, organizada como forma de aglomeração, com polos autônomos formados por conjuntos de caixas-pretas que irradiam uma neutralização do território.

Para Jameson (1989), a desterritorialização implica um novo estado de coisas "em livre flutuação", na qual a forma substitui o conteúdo e as características individuais dos objetos se tornam meras construções de marketing.

A arquitetura dos museus contemporâneos tornou-se cada vez mais espetacularizada, com o objetivo de criar repercussões midiáticas e proporcionar um grande acontecimento urbano. Essas imagens são reproduzidas e disseminadas mundialmente, buscando uma inserção no circuito do turismo cultural.

Os museus adquiriram grande destaque no panorama político e cultural das cidades contemporâneas e deixaram de ser compreendidos apenas como um espaço de estocagem de objetos de valor histórico ou cultural e passaram a ser 
considerados como um investimento lucrativo.

Grandes projetos de desenvolvimento e criação de instituições culturais transnacionais estão influenciando profundas reestruturações nas cidades, em diversos países do mundo.

Estas intervenções exigem novo repertório técnico e institucional, incluindo a readequação dos espaços museográficos e a elaboração de novas estratégias para a ação no espaço urbano.

Para o pleno êxito do engajamento da arte em espaços urbanos, o artista deve compreender que a cidade é composta de inúmeras camadas temporais, onde a evocação de imagens memoráveis serve-se dos momentos atuais e instaura uma nova forma de se relacionar com a obra.

A caixa expositiva do museu, antes o único elemento de mediação e normatização de comportamentos do público, é conectada a uma série de aparatos técnicos e cenográficos que conformam o museu em um lugar controlado ou ainda um não-lugar, como nas palavras de Marc Augé (1992).

Para o autor, os não-lugares são espaços constituídos com fins específicos, normalmente vinculados ao trânsito de massa (de pessoas e/ou de mercadorias), em que as relações dos indivíduos com esses espaços são previstas e programadas.

De uma organização estática, o museu assumiu um caráter dinâmico, se tornando um espaço em contínua transformação, com estrutura flexível e princípios abertos a revisões, produzindo uma multiplicidade de alternativas ao problema.

Isso reflete as diversas visões e interpretações conceituais que se manifestam atualmente, em que a definição de museu está cada vez mais ampliada e representa um universo de possibilidades e potencialidades para estabelecer seu 
sistema de relações entre a sociedade, o artista e a cidade.

A definição de Museu inclui Institutos de Arte, Centros Culturais, Museus de Ciência e Tecnologia, Sítios Arqueológicos, entre tantos outros. No entanto a definição utilizada é menos importante face à sua importância cultural para a sociedade contemporânea.

A cultura e a arte, por meio das TIC's, estão levando aos museus um tipo de relação que rompe com o espaço de exposições tradicional e altera as formas de percepção e fruição dos objetos artísticos. Se levarmos em conta que o espaço cibernético da Internet pode oferecer o contato com o conteúdo artístico de um museu, a experimentação ou visualização de web-art, ou mesmo assumir a forma de um museu inteiramente virtual, então o conceito de museu perde-se no universo de modelos existentes.

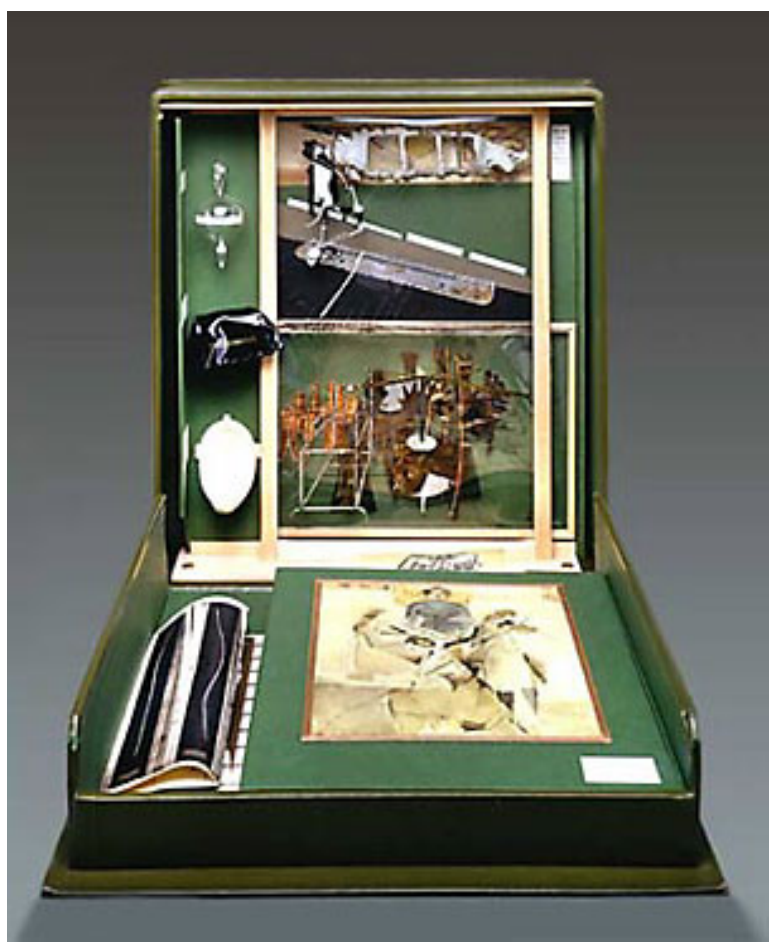

Figura 4. Museu portátil, Duchamp, 1941.

Talvez o modelo de Duchamp (1941), de miniaturização e portabilidade do museu (figura 4), tenha adquirido uma nova dimensão com a possibilidade de 
desmaterialização completa tanto da obra de arte como do próprio museu.

A ideia de museu como instituto de pesquisas, como nos moldes do Ars Electronica, Media Lab e V2 (institutos europeus de pesquisa sobre arte e tecnologia), se tornou um registro importante da cultura eletrônica a partir dos anos oitenta.

No início, foram criados e financiados pelo poder público, como a maior parte dos museus, visando oferecer um novo tipo de espaço dedicado às artes eletrônicas. O termo museu às vezes dá lugar a nomes como laboratório de mídias ou instituto de pesquisas, demonstrando o caráter científico que a instituição assume para si.

O próprio museu passa a abrigar espaços de pesquisa e desenvolvimento de novas tecnologias com aplicações artísticas, realizando projetos em parceria com artistas, engenheiros, programadores, arquitetos e outros profissionais que integram uma equipe multidisciplinar.

\section{Capítulo 3 - Arte e Tecnologia}

Neste capítulo, será elaborado um quadro teórico sobre as transformações da imagem a partir do pós-moderno, a fim de inserir algumas questões referentes à construção da estética e das formas de fruição e percepção próprias da arte multimídia e da cultura contemporânea.

Será realizado um levantamento histórico sobre as principais instituições internacionais e centros de pesquisa, produção e exibição de arte digital, relacionando seus principais artistas, obras e pensadores. 
Para contextualizar o Brasil no cenário internacional, será realizada uma análise de alguns museus internacionais que trabalham com estas mesmas questões, auxiliando na delineação do panorama institucional, arquitetônico e artístico e na construção de critérios de análise e reflexão sobre os museus contemporâneos.

\title{
3.1 AS TRANSFORMAÇÕES DA CULTURA DA IMAGEM A PARTIR DO PÓS-MODERNO
}

\begin{abstract}
As imagens que se destacaram de cada aspecto da vida fundemse num fluxo comum, no qual a unidade dessa mesma vida já não pode ser restabelecida. A realidade considerada parcialmente apresenta-se em sua própria unidade geral como um pseudomundo à parte, objeto de mera contemplação. A especialização das imagens do mundo se realiza no mundo da imagem autonomizada, no qual o mentiroso mentiu para si mesmo. O espetáculo em geral, como inversão concreta da vida, é o movimento autônomo do não-vivo. (Debord, 1997, p.13).
\end{abstract}

Como observado no capítulo anterior, arte e tecnologia estão intimamente ligados desde a concepção de arte enquanto transformação da matéria segundo uma intencionalidade proposta pelo homem. A arte envolve o fazer humano e é um dos traços que permitem o desenvolvimento da cultura.

Obviamente, os meios disponíveis e as representações apresentadas fazem parte de um mesmo contexto histórico e podem ser utilizadas como um caminho para a decodificação das ideias e técnicas presentes em uma obra de arte.

Em uma pintura rupestre da idade da pedra, podemos estabelecer dois critérios básicos de análise: uma formal e outra de conteúdo. A partir da forma, 
seria identificável uma ação protagonizada por figuras humanas contra um animal semelhante a um touro.

Esta análise puramente formal seria seguida de uma tentativa de decodificação do significado destas imagens, que poderiam ilustrar um sacrifício ritual, um momento de festa ou caça. Além disso, uma análise material poderia identificar os pigmentos, ferramentas e método utilizado para produzir tais desenhos.

Deste modo, são respondidas as principais perguntas sobre o quê representam os desenhos (homens e touros), sobre como foram realizados os trabalhos (pigmentos vegetais ou pedras lascadas) e qual o conteúdo, ou matéria expressa pelos desenhos (ritual ou caça).

Este tipo de análise contribui para uma reflexão sobre as relações entre arte e tecnologia. Uma conclusão precipitada poderia crer que a arte, sujeita aos meios e técnicas disponíveis a cada época, estaria necessariamente condicionada às possibilidades das novas ferramentas.

No entanto, esta reflexão tende a condicionar a arte às suas ferramentas, enquanto o essencial consiste não nos meios de produção ou reprodução, mas no desenho, no projeto, na intenção desenvolvida pelo artista para chegar a um objetivo estético, sensorial ou reflexivo.

Utilizando esta abordagem, o objeto de interesse situa-se na justaposição entre o objeto artístico e a pessoa que está diante dele. O objeto em si e todas as suas consequências ontológicas só são possíveis por meio do espaço que existe entre as coisas e os seres. O artista necessita deste espaço para que ocorram as trocas de sensações e informações entre a obra e o público.

Esta afirmação conduz à ideia de que sem o público a obra simplesmente não 
existiria, ou seja, o artista depende desta exposição para que seu trabalho tenha visibilidade e seja conhecido. A partir do séc. XVIII museu se torna o espaço próprio para a fruição da arte, sendo planejado e projetado para este fim.

No entanto, com o surgimento das vanguardas artísticas no começo do séc. $\mathrm{XX}$, os artistas colocaram em pauta os limites da sintaxe da pintura, expandindo a tela para fora do plano bidimensional e diluindo as divisões categóricas entre os distintos campos da arte, como pintura, escultura, música, teatro e fotografia.

É evidente que esta transformação da arte faz uso de todos os recursos e técnicas disponíveis para criar sensações típicas da sociedade industrial da época, com suas referências às máquinas e ao modo de vida das novas metrópoles. Esse universo imagético frenético, a produção em série, os avanços da ciência e da psicanálise trazem para a arte um conjunto de mudanças que acaba criando uma série de conflitos com o espaço tradicional do museu.

A forma das obras muda porque o artista assim deseja e este seu desejo está repleto de intenções quanto às relações que se estabelecerão com as pessoas. É exatamente aí que a obra passa a existir, como uma máquina que precisa ser ativada para funcionar.

Se no início do século passado a interação e o choque com o público tornaram-se um dos recursos mais utilizados pelos artistas para rivalizar com o mundo acelerado e repleto de estímulos sensoriais das grandes cidades, o que se observa na atual sociedade da informação é a interação cibernética entre obra e espectador.

A cibernética, ou ciência do controle, surgiu como uma área do conhecimento com o objetivo de estudar as relações entre sistemas vivos e artificiais, buscando compreender seus mecanismos para atuar em seu controle. A questão principal 
gira em torno da comunicação, ou troca de informações entre os sistemas e internamente na sua própria auto-regulação.

O processo de retroalimentação, conhecido como feedback, é uma forma de controle do sistema a partir de entradas de informação baseadas em sensores e mecanismos de resposta e atuação. Um sistema de ar condicionado inteligente capta as alterações de temperatura do ambiente por meio de um termômetro e aumenta ou diminui a potência do refrigerador a fim de manter a temperatura escolhida.

Neste e em muitos outros exemplos, a natureza foi utilizada como inspiração, servindo de modelo para a criação de sistemas mecânicos autocontrolados. A cibernética se desenvolveu e é utilizada para analisar problemas econômicos, sociais, criar máquinas e auxiliar na produção industrial.

Com suas pesquisas, Wiener (1954), alterou a análise dos sistemas como um conjunto de fenômenos lineares determinados pela causalidade para um movimento cíclico de regulação que permite criar sistemas autônomos.

Uma consequência de extrema relevância é que se os sistemas, para funcionarem, necessitam de algum tipo de sensor, o que realmente está em jogo é a manipulação da informação, não o mecanismo em si.

Após compreendido o modus operandi do sistema, pode-se manipular e transformar uma determinada informação em movimento, força, ou uma outra informação. Apesar desta ciência ter se desenvolvido em uma época em que os recursos de que se dispunha eram basicamente analógicos, na atual era da informática, tudo o que nos cerca está repleto de mecanismos ou sistemas cibernéticos.

Com a miniaturização dos equipamentos e desenvolvimento dos sistemas de 
programação, praticamente qualquer produto pode desempenhar uma infinidade de tarefas com muita rapidez e ao alcance das mãos. Talvez o equipamento que mais represente isso seja os smartphones, que se conectam à internet, possuem câmera de vídeo e fotos, possuem localizador GPS, utilizam um sistema operacional e executam os programas instalados pelo usuário.

Dessa forma, as pessoas estão a todo o momento conectadas e com um computador ultra portátil à mão, que permite realizar diversas tarefas e registrar sons e imagens de uma maneira quase intuitiva. Como a questão física do tamanho foi resolvida, o que passou a ter importância foi a manipulação da informação dentro do próprio sistema, o que desloca o problema para a interface com o usuário.

Nesse momento, a forma, ou o desenho da interface, se tornam prioritários para lidar com sistemas complexos e facilitar a sua utilização pelas pessoas. $\mathrm{O}$ caminho mais apropriado seria que a informação fosse tratada de uma maneira intuitiva, em que o funcionamento do sistema fosse praticamente autoexplicativo.

Um sinal disso é a crescente utilização das telas sensíveis ao toque (touchscreen), em que o usuário interage com a informação tocando diretamente na tela. Dessa forma, é dispensado o uso de teclados, mouse, ou outro dispositivo para inserir dados no sistema.

Se a interface dos sistemas computacionais se resume a uma tela que reproduz imagens e permite a interação sem nenhum outro dispositivo, poderíamos afirmar que a arquitetura pode se transformar em uma extensão dessa ideia. $\mathrm{O}$ motivo básico é que a arquitetura se configura espacialmente como um conjunto de planos e superfícies que estabelecem um tipo de interface com as pessoas.

Materialmente é assim que um edifício interage com um indivíduo, 
desenhando superfícies no espaço, formando paredes, delimitando áreas, como uma casca que se desdobra conforme as intencionalidades buscadas pelo arquiteto. Ambos participam do mesmo modelar de superfícies, jogando com conceitos abstratos que são transferidos para o mundo sensível.

A pintura e a escultura participaram sempre mais intimamente na concepção da arquitetura, muitas vezes pensadas com uma unidade que faz desaparecer os limites entre elas. Se a escultura é a arte que mais se aproxima da arquitetura por sua manifestação tridimensional, a pintura era antes uma extensão das superfícies pré-arquitetônicas, ou uma forma de imprimir significados nas paredes das cavernas.

Após a criação de outros suportes, a pintura pôde se emancipar da arquitetura e se diferenciar da superfície das paredes construídas e permitir a mobilidade e comercialização dos quadros.

Arte e arquitetura comparecem cada vez mais integradas formalmente, explorando as características dos planos criados e da utilização da reprodução de imagens diretamente nas faces dos edifícios. A hierarquia e distinção entre paredes, chão e teto parece se diluir e a arquitetura vai se conformando como um desdobramento de planos que vão se sucedendo em uma série de continuidades e rupturas que organizam o espaço.

Poderíamos dizer que a arte está explorando as novas tecnologias com o objetivo de criar sistemas cibernéticos e provocar um novo tipo de interação entre a obra e o espectador. O conceito de interação dentro da arte não é algo recente e muitos trabalhos, desde o início do século passado, exploraram essa ideia em suas obras. Um caso emblemático no Brasil é o conjunto de peças chamada Os Bichos (1960), de Lygia Clark, que são constituídas de planos metálicos recortados, e 
unidos entre si por dobradiças. O público é convidado a mexer nas peças e transformá-las conforme as possibilidades oferecidas pelo sistema de dobradiças e a cada momento surgem novos "bichos", como em um origami mutante (figura 5).

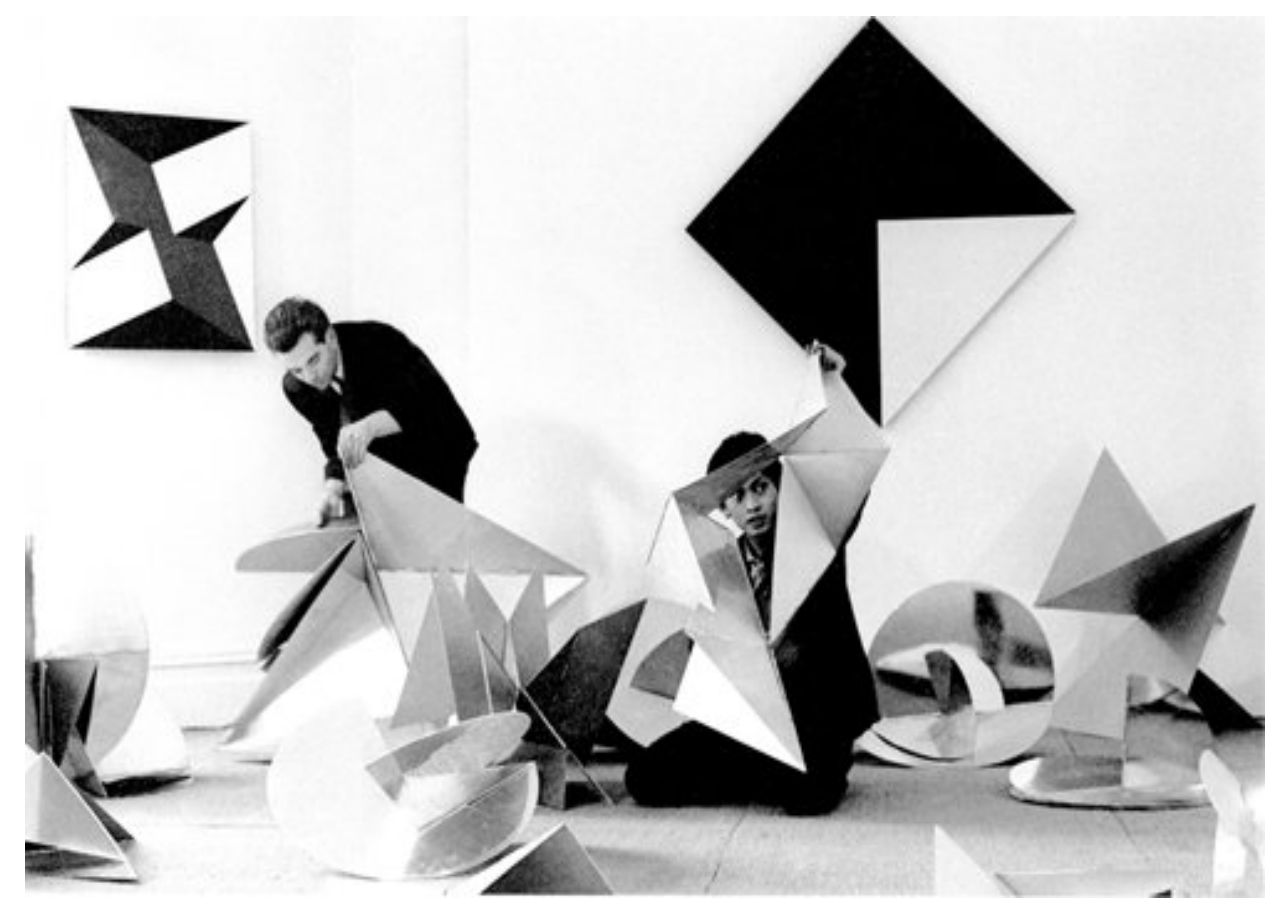

Figura 5. Bichos, Ligia Clark, 1960.

Existe uma aparente liberdade de ação do espectador sobre a obra, como se ele passasse ao papel de artista, mas em última instância, todos os movimentos e possibilidades oferecidos pela peça são limitados e definidos anteriormente pelo artista. Portanto, o objeto artístico expande suas interfaces e passa a seguir um princípio de organização que adota estratégias para envolver as pessoas com sistemas dinâmicos.

Os games, ou jogos eletrônicos, constituem um universo controlado de ações e reações, que nos conduz a um objetivo previamente estabelecido. O ser humano possui em si, uma capacidade ímpar de compreender sistemas, deduzir regras e 
produzir ações para alcançar seu objetivo e esta é, sem dúvida, uma das principais características que nos distingue dos outros seres.

Segundo o filósofo Huizinga (1938) a capacidade de desenvolvimento e o nível de avanço a que chegamos foi possível graças à capacidade humana de estabelecer regras e criar jogos. Ele definiu que a espécie humana poderia ser chamada de Homo ludens devido à importância dessa diferenciação.

Huizinga (1938) define jogo como:

"(...) uma atividade voluntária exercida dentro de certos e determinados limites de tempo e espaço, segundo regras livremente consentidas, mas absolutamente obrigatórias, dotado de um fim em si mesmo, acompanhado de um sentimento de tensão e alegria e de uma consciência de ser diferente da vida cotidiana" (HUIZINGA, 1938, p.33).

À medida que a arte se aproxima dos games, por meio das interfaces e sistemas computacionais, o artista assume o papel de programador, ou mais propriamente, de designer (projetista) de programação. Cada obra de arte é como um jogo, em que o espectador busca compreender suas regras, experimentando e interagindo com ela. Nesse jogo, o objetivo não é necessariamente ganhar ou perder, mas despertar a percepção lúdica pelo processo de interação proposto pelo artista. Muitas vezes o objetivo é apenas entreter os sentidos e criar sensações, mas em algumas obras a imersão estabelece relações cognitivas que vão além do sensorial e alcançam maior nível de reflexão e significado.

A arte envolve sempre duas categorias de abordagem: uma sensorial e perceptiva e outra simbólica e reflexiva. Ambas contribuem para um entendimento completo do objeto artístico. Poderíamos, de outra forma, visualizar estes conceitos na dualidade encontrada em forma e conteúdo, ou forma e matéria.

Flusser (2010) define que a matéria é a característica provisória das coisas, enquanto a forma é uma representação ideal e imutável, formulada pelo 
pensamento. A madeira de que é feita uma cadeira pode ser substituída por aço, ou esta mesma madeira pode queimar e se transformar em cinzas, mas a forma da cadeira jamais de transformará e cada uma das suas reproduções é apenas um modelo imperfeito daquele conceito ideal.

Quando estamos diante do caos da realidade, em sua abundância de estímulos, não conseguimos distinguir as coisas com clareza e isso só é possível a partir do momento em que iniciamos um processo de identificação das formas ideais que estão escondidas sob a aparente falta de lógica da natureza.

A capacidade de projetar modelos mentais acaba aproximando as atividades do arquiteto, do designer e do cientista, enquanto pessoas que estão sempre a criar modelos. A forma de uma mesa, assim como a fórmula da gravidade, são modelos concebidos para alcançar um fim e possuem um aspecto formal imutável, independente do tempo e do espaço. Para Flusser (2010, p.30), todos são designers, a partir do momento em que as formas não são descobertas, nem invenções, nem ideias platônicas, nem ficções, antes recipientes para fenômenos (modelos). E a ciência não é nem verdadeira, nem falsa, mas sim formal (projeta modelos).

Desse modo, a matéria do design, assim como da arte, consiste no modo como aparecem as formas produzidas, o que está condicionado então às questões técnicas específicas. Uma mesma obra pode assumir diferentes formas de apresentação, a partir de medias variadas e mesmo assim manter uma ideia central.

É como um livro, que vira filme, que se transforma em teatro, em música e assim por diante, demonstrando que a forma permanece a mesma, mas a matéria, pode ser modificada e alterada de inúmeras maneiras. Seria possível representar a 
fórmula $E=m c^{2}$ por meio de uma instalação interativa, por exemplo? É exatamente isso que os artistas fazem ao transformar conceitos formais abstratos em matéria concreta enformada.

Por envolver uma diversidade de áreas como mecânica, robótica, eletrônica, programação computacional e até mesmo biologia, os projetos são desenvolvidos por grandes equipes e muitas vezes a concepção da obra depende de alguns parâmetros e informações técnicas que escapam ao conhecimento do artista.

Nesse âmbito todos partilham e estão envolvidos em um projeto maior, similar ao que acontece nos projetos de arquitetura, onde cada um dos profissionais trabalha com a intenção de unir as partes em uma obra coesa.

Qual seria o limite então entre a arte e um game, já que as manifestações artísticas foram assumindo cada vez mais o lado lúdico das obras, o que muitas vezes se torna uma busca maior para a sedução dos sentidos e entretenimento do que em uma fruição artística com profundidade reflexiva e crítica.

A indústria de games possui grande retorno financeiro e um dos motivos é a capacidade dos jogos de gerar experiência emocional nas pessoas, provocada por sistemas de simulação cada vez mais realistas.

A realidade virtual e a criação de espaços tridimensionais interativos possibilitaram a criação de mundos artificiais, tão convincentes que as respostas emocionais são bastante reais para quem está imerso no jogo. Neste caso, o objetivo é justamente ludibriar os sentidos e fazê-los acreditar naquilo que está se vendo, uma estratégia utilizada, por exemplo, desde o teatro até no cinema.

De fato, a cultura dos games não é tão recente, mas o que vemos é uma aproximação cada vez maior do cinema, o que já gerou obras em que o jogo é planejado como o roteiro de um filme e vice-versa. O filme pode assumir diferentes 
finais de acordo com as escolhas do espectador, o que gerará diferentes filmes para cada espectador. É como se cada pessoa assumisse uma parte do roteiro, definindo o caminho da história por meio de suas escolhas.

Apesar dessa liberdade de escolha ser em última análise determinada pelo designer que projetou a obra, sua abertura à entrada de dados e possibilidade de diferentes resultados é um aspecto muito relevante e a principal característica a ser destacada nesta dissertação.

O tipo de arte que interessa aqui é aquela que utiliza das interfaces eletrônicas e mecânicas para estabelecer um sistema cibernético entre obra e espectador. Este funcionamento cíclico de entradas e saídas de informação entre dois sistemas é ampliado cada vez mais, com a utilização das redes de informação, (como celulares, GPS e outras redes particulares) para gerar uma dinâmica de trocas de informações sem precedentes.

Os trabalhos de net art, por exemplo, podem simplesmente não ter uma forma física e se apresentar apenas enquanto um ambiente interativo disponível na Internet, portanto acessível de qualquer terminal com um navegador (o que hoje está ampliado na forma de celulares, notebooks, televisores, desktops, videogames, tablets, entre outros eletrodomésticos). A tendência é que com a diminuição do tamanho dos componentes, seja possível conectar qualquer coisa que imaginemos em uma rede.

A arte passa a utilizar estes recursos para criar novas formas, utilizando esta base de dados para gerar novas informações. As imagens produzidas hoje se tornaram digitais e na arte não foi diferente, onde a utilização de muitas tecnologias emprestadas do cinema e da produção de games, ajuda a criar projeções ou telas para a geração de imagens digitais. Isso implica na necessidade de um sistema 
digital de projeção para as exposições.

Se as telas sensíveis ao toque se tornaram um novo padrão para a indústria, sistemas baseados em sensores infravermelho e reconhecimento de imagem, estão cada vez mais presentes em consoles de videogames, possibilitando uma interação com a informação sem a necessidade de utilizar algum controle físico ou tocar em alguma superfície.

Os novos dispositivos móveis possuem giroscópio e acelerômetro, sensores que determinam a direção e velocidade do movimento. Estes dados são processados por softwares para executar movimentos e controlar objetos nos ambientes virtuais.

Desse modo, todos os movimentos podem rastreados e a informação utilizada para acompanhar as posições e determinar seu percurso em um mapa, por exemplo. Com isso, os guias de museus se tornam mais precisos e apontam onde a pessoa está e oferecem informações específicas sobre este local.

Com o barateamento das telas de LCD, tornaram-se comuns nos museus a proliferação de painéis, totens e pontos de acesso para se comunicar com o público

A arte digital pode ser reproduzida por diversos equipamentos, o que permite que seja disponibilizada pela internet ou veiculada em outra mídia. Ao invés de um quadro ou tela física, o que se compra é a informação digital da imagem e o que a torna real é outro equipamento que decodifica os dados e reconstrói a obra.

Podemos comprar uma imagem gerada inteiramente pelo computador, por meio de um site, realizar o download do arquivo e utilizá-lo de forma impressa ou apenas projetada. Isso trouxe enormes problemas pela facilidade de troca e reprodutibilidade da informação digital, envolvendo direitos autorais e controle na veiculação da obra. 
É evidente que esta discussão está permeada de muita polêmica, já que envolve interesses comerciais, o que é um grande desafio para os artistas e indústria cultural, pois como aconteceu com a música, todas as mídias digitais podem ser copiadas e compartilhadas com poucos recursos, de uma maneira rápida e sem perdas.

Para o professor e pesquisador de arte e comunicação digital Cícero Inácio da Silva há o risco de tornar o uso da tecnologia banalizado e utilizado apenas como forma de espetacularização:

(...) ando bastante exausto dessas exposições que só mostram gadgets de todos os tipos, mas que não se pensam em um cenário mais amplo, tanto artístico quanto museológico. E isso talvez seja agora necessário para que a arte e tecnologia não vire uma nota de rodapé no grande livro imaginário da História da Arte e dos Museus (SILVA, 2012, entrevista em anexo).

Com o intuito de gerar mais dados e informações sobre estes fenômenos, foi realizado um levantamento de obras que se encaixam no que foi definido anteriormente como arte cibernética e interativa, priorizando aquelas que apresentam maior material para análise reflexiva.

A obra Access (SESTER, 2003) por exemplo, permite interessantes abordagens sobre as relações entra obra $\mathrm{x}$ espectador, arte $\mathrm{x}$ arquitetura e arte $\mathrm{x}$ tecnologia. Ela é praticamente imaterial, já que a única coisa que vemos é a projeção de um círculo de luz no chão, semelhante a um canhão de luz, com o diâmetro para abrigar uma pessoa em sua área.

Este canhão de luz se movimenta por um pátio coberto alto e relativamente estreito, com outros andares que se abrem para ele, possibilitando diversos pontos de vista para seu interior. A atmosfera é sóbria, com muito concreto e uma luz suave, filtrada por uma cobertura translucida, que ilumina, mas mantém uma sensação de confinamento. 


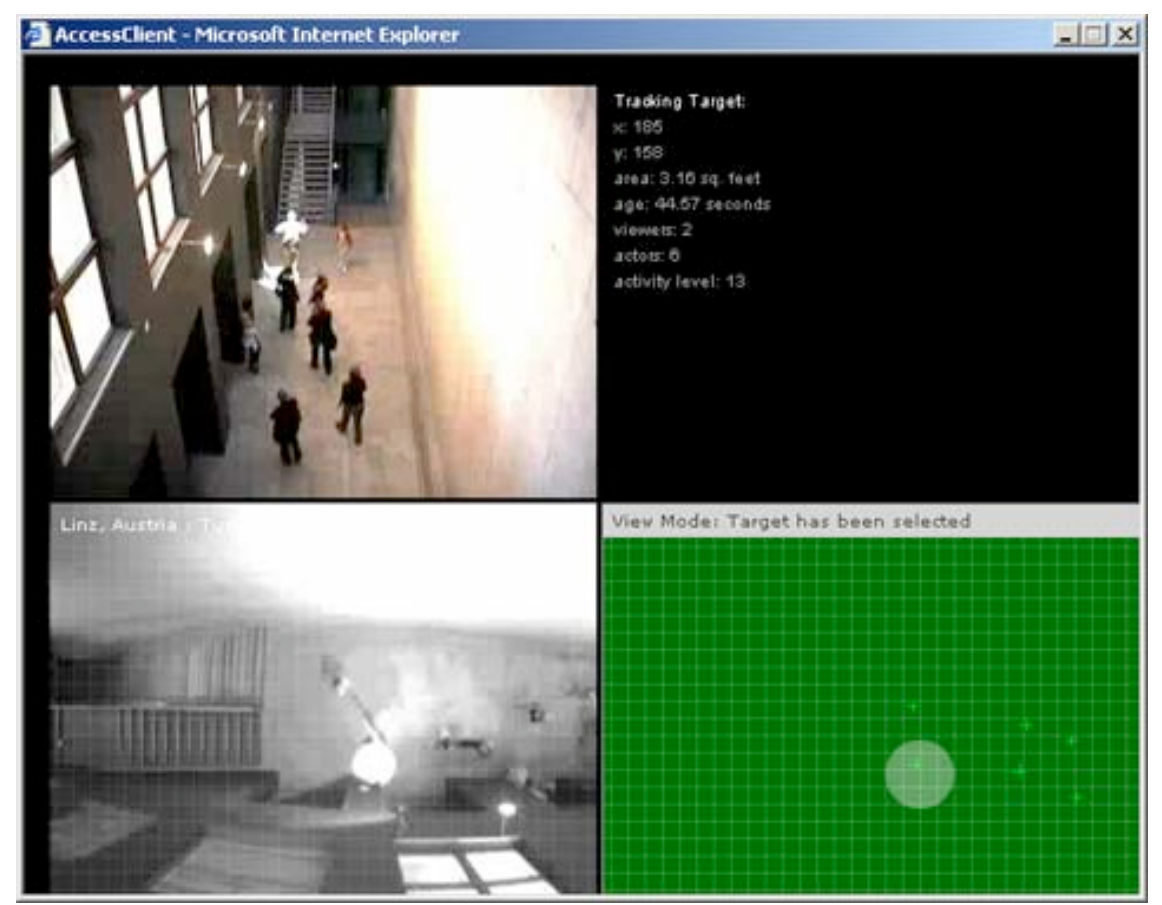

Figura 6. Imagem da tela de interface da obra Access controlada à distância por meio da internet.

As pessoas que percorrem este espaço são obrigadas a travessá-lo longitudinalmente, enquanto um sistema de câmeras e sensores posicionados no teto rastreiam seus movimentos. Estes sensores geram uma imagem em que o movimento das pessoas pode ser acompanhado. Estas imagens são enviadas para um site onde qualquer pessoa pode acessar, visualizar os movimentos das pessoas e selecionar uma delas para se tornar seu "alvo" (figura 6).

A partir deste momento, o canhão de luz é acionado e passa a acompanhar todos os movimentos do alvo escolhido, perseguindo-o por toda a extensão do espaço. Simultaneamente a essa perseguição, são enviadas mensagens sonoras direcionadas àquela pessoa, com mensagens como: continue andando e mostre alguma identificação, por favor; ok, este é o seu momento, esta é sua oportunidade, não fique parado, nos ofereça algum entretenimento; ei, o que você está fazendo 
aqui?; ou existem 2.630 pessoas te assistindo nesse momento" e outras mensagens condicionadas a movimentos como correr, mudar bruscamente de direção, etc.

Vale destacar a relação de interação com as pessoas, tanto aquelas que estão percorrendo o corredor, como aquelas que estão navegando pelo site e escolhendo seus alvos. Neste caso existe um sistema que recebe informações de duas pessoas, criando uma interação à distância. Além disso, as outras pessoas que estão percorrendo o pátio, estão observando as reações das pessoas e a plasticidade de seus movimentos, destacada pelo forte facho de luz (figura 7).

O sistema é todo controlado por softwares e utiliza um conjunto de câmeras e sensores para capturar o movimento e um braço mecânico, que movimenta um espelho circular que reflete a luz de um projetor para a direção escolhida. Tudo isso acontece em tempo real e com uma velocidade muito grande, de modo que mesmo que a pessoa corra ou faça movimentos rápidos e bruscos, o foco de luz o acompanha com precisão.

O uso do espaço foi perspicaz e revela suas característica de panopticum, espaço controlado em que existem pontos de onde se pode observar tudo. Desse modo, é intensificada a sensação de ser vigiado que existe no espaço, revelando sua dimensão perturbadora.

O facho de luz direcionado às pessoas provoca reações que despertam tanto a vontade de se esconder por estar sendo observado, como o desejo de se expor, atraindo as atenções para si, em uma atitude exibicionista. Existe um jogo entre observar e ser observado, traduzido de um modo artístico que provoca diversas reflexões sobre a sociedade vigiada que vivemos, ou mesmo a vontade ou necessidade de exposição narcisista que assistimos pelos meios de comunicação. 


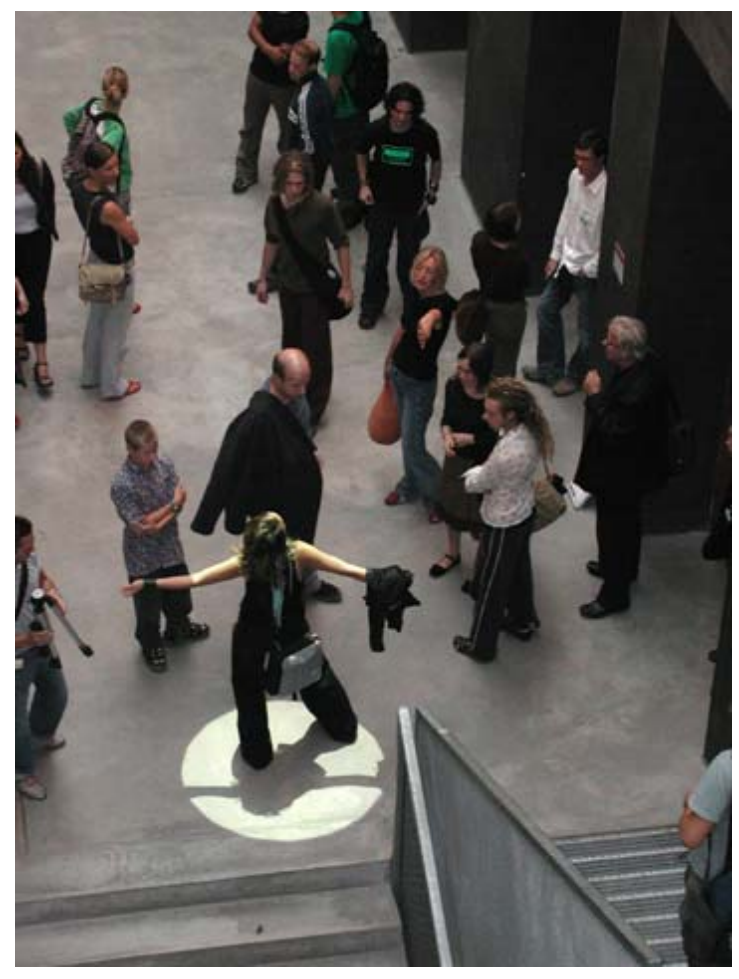

Figura 7. SESTER, Access, 2003.

A tecnologia em si, praticamente não aparece e permanece subjacente aos mecanismos e programação, expondo não a si, mas as pessoas que participam da interação. Acontece uma inversão interessante, que coloca o espectador dentro da obra e faz dele uma parte de seu mecanismo de funcionamento. Se não houver pessoas para acionar o sistema, a obra simplesmente não acontece, não existe.

É interessante notar como uma obra aparentemente simples, oferece ao mesmo tempo entretenimento, reflexão e qualidades sensíveis. Esta obra consegue unir estes aspectos de maneira coerente em forma de arte, com uma mistura de instalação, teatro e dança, já as outras pessoas assistem às reações e movimentos do alvo, como em um pequeno espetáculo. Assim que se acende a luz, você é o centro das atenções.

As noções de privacidade e individualidade são expostas de forma 
interessante, que utiliza os significados da luz, de revelação e exposição e faz referência às luzes teatrais dos shows e espetáculos, que destacam o objeto iluminado, em contraste com o fundo escuro.

Ao mesmo tempo revela o mecanismo que dá suporte e finalidade ao sistema, que é determinado por alguém, alguma consciência oculta detrás de aparente impessoalidade da máquina ou sistemas cibernéticos. A escolha do alvo é sempre determinada por outro ser humano, com interesses e motivações totalmente desconhecidas.

O que fica demonstrado é que todo o aparato técnico e as ferramentais digitais só servem para algo quando existe uma entrada de dados feita por um ser humano e que envolve outro ser humano, estabelecendo uma rede de comunicação cibernética, como acontece diariamente em nossas vidas. O foco é deslocado da coisa ou matéria aparente da obra para a sua essência ou conceito fundamental, expondo o que é mais importante: as ações humanas.

A aparente impessoalidade se revela como uma trama de ações e reações sempre iniciada por alguém, colocando a antiga, mas sempre presente questão sobre se o homem cria as máquinas para depois ser escravizado por elas. A forma com que a obra coloca todas estas questões é o que torna a obra repleta de significados e sensações que criam uma experiência ao mesmo tempo lúdica e intelectual, corporal e cerebral. A experiência completa e a interação entre os sistemas é que diferencia este tipo de obra com viés crítico e conceitual daquelas que, ou expressam apenas a vontade e exposição da técnica em si, ou permanecem em um nível da interação como pura forma de entretenimento, sem despertar reflexões ou transmitir informações.

O objetivo não é criar juízos de valor de qualquer natureza, mas realizar uma 
análise dos fenômenos enquanto tal, avaliando suas características conforme os conceitos estabelecidos anteriormente e observando a forma (desenho, design, projeto, ideia) da obra e sua matéria (sistemas, interfaces, mecanismos, materiais, plasticidade).

O estúdio de Usman Haque (www.haque.co.uk), artista radicado em Londres, segue uma linha de pesquisa que se concentra na fusão daqueles elementos em arquitetura. Seus trabalhos se situam na fronteira entre a arte e a arquitetura e procuram explorar as relações que acontecem entre as pessoas e o ambiente em que estão.

Os sistemas envolvem tanto a construção de equipamentos e espaços físicos como a programação de softwares para o gerenciamento dos sensores e atuadores. Por meio de algoritmos, esse conjunto de sistemas é capaz de desempenhar diversas funções, como detectar uma posição no espaço de um som, odor, temperatura, telefone celular e qualquer parâmetro quantificável pelos sensores.

Na obra Primal Source (2008), o estúdio de Haque desenvolveu um sistema que capta os sons emitidos pelas pessoas para gerar imagens abstratas que são projetadas em tempo real em uma nuvem de partículas d'água produzida por um poderoso aspersor (figura 8).

Este aspersor gera um de leque luminoso, onde diversos projetores conectados a um computador recebem os sinais de microfones posicionados frontalmente ao público e transformam esta informação em imagens e animações que criam um espetáculo de luzes. 


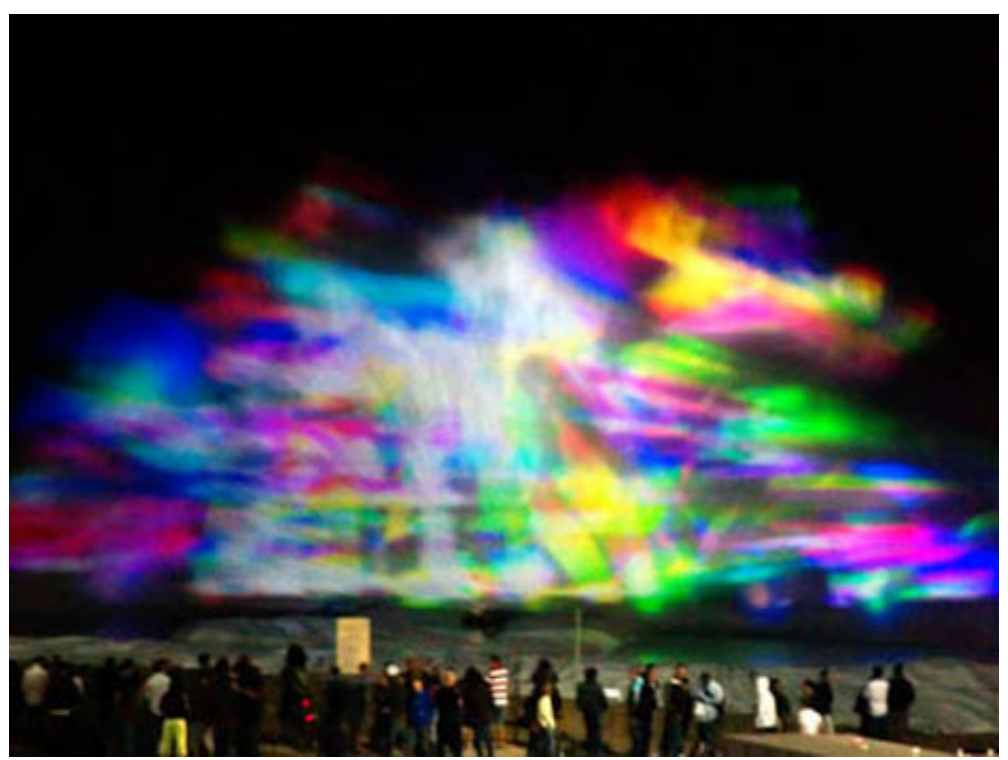

Figura 8. Instalação Primal Source, EUA, 2008.

Apesar da interatividade proposta e da beleza visual promovida pelas cores e imagens que parecem flutuar magicamente no ar, esta obra não apresenta uma perspectiva de reflexão crítica ou abordagem que desperte tensões ou relações de sociabilidade e comunicação entre os sistemas obra-espectador-espaço.

A informação recebida pelos microfones (gritos da plateia) é transformada em imagens que não trazem em si conteúdo ou matéria a ser recebida e interpretada para realimentar o sistema. Os dados ambientais do lugar aparentemente não fazem parte da obra e pressupõe a neutralidade do espaço, para que haja uma autonomia da instalação no ambiente em que está montada.

Nesse caso, parece que os recursos tecnológicos e a interatividade funcionam para a criação de um evento espetacular, que às vezes lembra um show pirotécnico. No entanto, as possibilidades criadas pelo sistema são inspiradoras e o resultado plástico é surpreendente e impressiona pela tridimensionalidade das projeções e qualidade das formas e cores. 


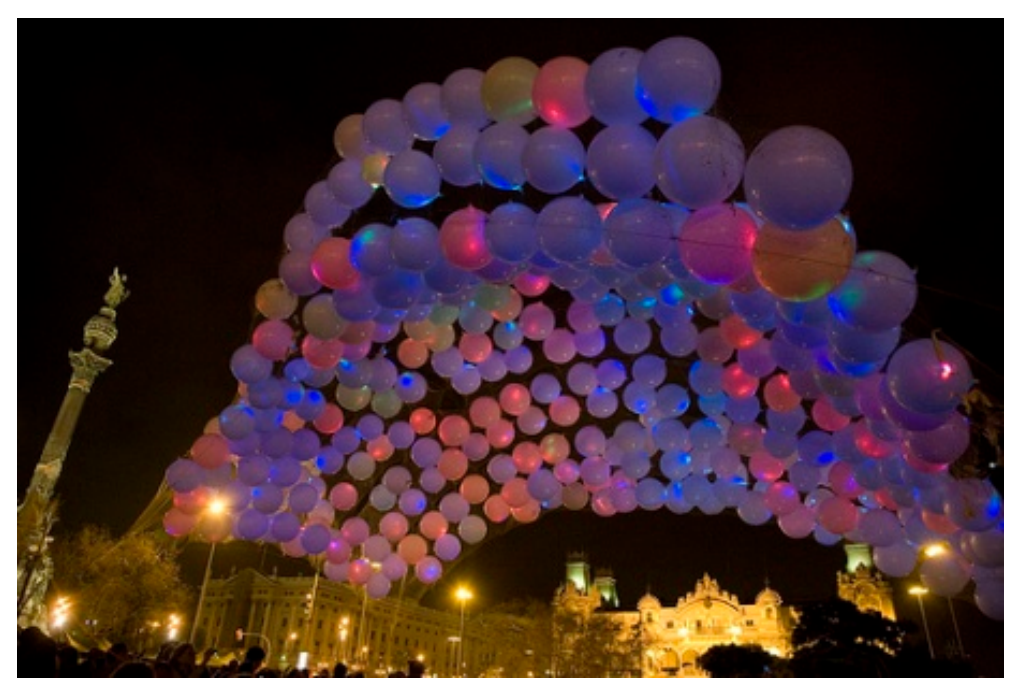

Figura 9. Instalação da obra Control.Burble.Remote, Barcelona, 2010.

A obra Control.Burble.Remote, realizada pelo mesmo artista, premiada no Media Art Festival do Japão, explora o conceito e interatividade no ambiente urbano e trabalha com materiais que geram um resultado plástico que dá força ao conceito da obra. Foram utilizados balões brancos inflados com hélio arranjados em uma malha, que formam uma nuvem a uma altura entre quatro e cinco metros do chão (figura 9).

Os balões estão conectados a um computador que controla todo o sistema e cada um deles possui um equipamento de recepção de sinais infravermelhos e um conjunto de LED's. O público que se situa abaixo da nuvem de balões, é munido de controles remotos que permitem o envio de sinais aos balões, provocando mudanças de cor e intensidade luminosa nos LED's.

Desse modo, cada um dos balões se torna um pixel flutuante, que em conjunto forma uma cobertura luminosa e transforma a percepção do espaço. Com as pessoas interagindo e enviando sinais por meio dos controles remotos, a nuvem adquire uma dinâmica e comportamento que se altera constantemente conforme a 
participação das pessoas.

A obra foi montada em diversas cidades como em Londres e Barcelona, com adaptações de forma e tamanho da malha de balões, além do aperfeiçoamento de hardware e software.

A arquitetura, em seu sentido mais tradicional, sempre foi entendida como o objeto físico e estático que define nossos espaços e nos abriga por meio de elementos como paredes, pisos e coberturas. Haque procura uma forma de romper com esse paradigma, explorando qualidades menos concretas e mais sensoriais do espaço. Por isso ele desenvolveu os conceitos de hardspace e softspace (www.octodog.com/usman/), se referindo a estas duas interfaces presentes na arquitetura. Por um lado existe a estrutura física determinada pela materialidade da edificação e por outro os aspectos menos tangíveis, como os sons, os odores, o calor, as cores e luzes e mesmo as radiofrequências e outros tipos de ondas e campos eletromagnéticos que preenchem e permeiam os espaços.

O desafio proposto é integrar estes dois conceitos em uma arquitetura que forneça um suporte para essa interação e promova uma integração com as pessoas. Com isso seria possível alcançar uma linguagem arquitetônica que se comunique com todos os cinco sentidos, pois cada cultura percebe o espaço de diferentes maneiras, utilizando distintas combinações dos sentidos.

Quase em todos os seus trabalhos, Haque está interessado na noção do visitante como um performer, que é agarrado por uma rede de trocas e circularidade, como o equilíbrio instável da retroalimentação (feedback) de vídeo e áudio, bastante explorado pelos pioneiros da vídeo-arte Steina e Woody Vasulka.

A qualidade da obra está nessa diversidade de significados e informações que enriquece a experiência, abarcando os categorias sensoriais, intelectuais e formais. 
Como em um sistema, a obra também interage com o espaço, portanto o desenho dos museus troca informações com a arte, em um movimento dialético.

Com a ampliação da complexidade das obras e sua multidisciplinaridade, arte ciência e engenharia atuam de maneira integrada, reunindo uma grande equipe com conhecimentos complementares. Talvez este tenha sido sempre o modelo que os filósofos gregos buscavam definir em seus conceitos sobre a téchné e que os modernos buscaram reafirmar com a disciplina do desenho industrial, que reunia conceitos da arte com o conhecimento das técnicas e modo de produção industrial.

Evidentemente, os objetos artísticos se diferenciam daqueles objetos de consumo, por estarem desvinculados de uma finalidade puramente instrumental e comercial. Existem inúmeras definições e conceituações sobre o que é arte, buscando estabelecer propriedades necessárias e suficientes para que algo seja considerado arte. No entanto nenhuma delas conseguiu formular uma teoria que desse conta de todas as formas artísticas e suas incontáveis interpretações subjetivas.

O certo é que existe um sistema de valores condicionado por diversos interesses e categorias de avaliação que determina o que é ou não arte e que isso varia no tempo e no espaço, como pode-se observar ao longo da história. Nesse caso, o museu e seus curadores representam um dos lados desse sistema, determinando aquilo que deve ser exposto e valorizado enquanto uma obra de arte. Se o objeto está exposto em um museu, é indício de que tem valor artístico e a forma de apresentação da peça deve ser pensado para tornar isso evidente aos olhos das pessoas.

Existe uma percepção, ou emoção estética, que experimentamos ao se deparar com um objeto pensado e elaborado por outro ser humano, abrindo 
caminho para a construção de valores intrínsecos à obra. O foco está na comunicação formal e criação de significados que se estabelece entre arte e indivíduo.

Analisando com mais atenção, pode-se chegar a um denominador comum entre as atividades do artista e do arquiteto, pois ambos trabalham com a produção de formas e estão envolvidos com os mecanismos e técnicas necessários para realizá-las. Além disso, tanto a arte como a arquitetura fazem parte da produção

A atividade de dar forma às coisas, ou enformar, é a consequência de um plano inicial, de uma ideia abstrata ou um projeto. O processo passa sempre de um plano de imaginação para o de formalização material. Se ampliarmos nossa perspectiva, podemos pensar que toda atividade de imaginação e estratégia empreendida pelo homem com uma finalidade determinada se resume a uma projeção, ou desenho.

$\mathrm{Na}$ sociedade atual, o design se destacou no campo de conhecimentos humanos para constituir praticamente em uma ciência. No período do modernismo, o design foi tomado como a união da ciência e da mecânica com a arte, tornando possível a criação de um universo formal mais racional, belo e funcional. A partir de então, o design realizado para uma peça passou a ter mais valor que a coisa em si, ou material de que é feito.

Com o barateamento das linhas de produção e domínio das tecnologias por meio do uso da engenharia reversa, o valor de um objeto não está mais no seu material, durabilidade ou tecnologia exclusiva, o que mais importa é o desenho da peça, seu aspecto formal.

Considera-se que as questões levantadas sobre a consolidação da cultura da imagem são cruciais para instrumentalizar uma investigação da problemática que 
envolve a produção cultural de uma maneira geral, o que inclui a produção da arte, da arquitetura e da cidade.

O estudo sobre a cultura da imagem servirá para auxiliar no desenvolvimento do capítulo seguinte, onde serão tratadas as ressonâncias dessa nova cultura imagética na conformação dos museus contemporâneos.

Neste sentido, a leitura de Jameson (1989) é fundamental para a reflexão sobre as transformações da imagem ocorridas no pós-moderno, que repercutem de maneira crucial na produção artística contemporânea e estabeleceram novas maneiras de aproximação entre a arte e a sociedade, materializada nos museus das metrópoles contemporâneas.

Considerando que grande parte do que é produzido em forma de arte atualmente trabalha constantemente com a manipulação, produção e reprodução de imagens, foi realizada uma revisão bibliográfica com o objetivo de identificar as principais características e particularidades da cultura imagética da pósmodernidade, utilizadas na manipulação e veiculação de imagens que se tornou uma das principais características da cultura contemporânea.

A matriz jamesoniana será utilizada aqui como base teórica para auxiliar a compreender o caráter de tais transformações e também como instrumento de análise crítica das manifestações artísticas contemporâneas e da própria transformação dos museus.

A cultura contemporânea é entendida por muitos autores como um desdobramento ou exacerbação de determinados fenômenos surgidos principalmente durante a construção do pós-moderno.

A criação, manipulação e veiculação de imagens pela indústria cultural e sua utilização em quase todas as formas de produção do capitalismo é uma das marcas 
do que Jameson (1985) chamou de capitalismo tardio, uma etapa avançada de transformação e adaptação do capitalismo que se inicia a partir da década de 80 .

O próprio entendimento e percepção sobre o sentido da palavra imagem já indica algumas transformações ao longo da história, revelando que a natureza da imagem e a forma com que a compreendemos e utilizamos está diretamente relacionada à ontologia e à epistemologia humanas.

As diferentes definições de imagem e o que isso representa para a filosofia é uma discussão extremamente complexa, mas torna-se importante mencionar, mesmo que brevemente, algumas reflexões sobre o termo, que têm origem nos textos de Platão e Aristóteles.

A palavra imagem, derivada do latim: imago, significa, de modo geral, a representação (visual) de algo. Do grego antigo, remete à raiz etimológica do termo idea ou eidea, conceitos filosóficos desenvolvidos por Platão (384 aC.).

De acordo com Barthes (1990), a palavra "imagem" deveria estar ligada à raiz de "imitari", já que, para ele, a principal questão é saber se a cópia, a representação analógica, pode produzir verdadeiros sistemas de signos e não somente uma acumulação de símbolos.

Para Barthes (1990), a imagem traz em si uma natureza linguística, carrega significados que vão além da duplicidade do objeto, já que a imagem é entendida como re-presentação, ou seja, uma nova apresentação.

Para Debord (1992), toda a vida das sociedades, nas quais predominam as modernas condições de produção, se apresenta como uma imensa acumulação de espetáculos. Tudo o que antes era vivido diretamente torna-se uma representação.

O espetáculo é, ao mesmo tempo, o resultado e o projeto do modo de produção existente. Sob todas as suas formas particulares, informação ou 
propaganda, publicidade ou consumo de entretenimentos, o espetáculo constitui o modelo atual das relações sociais.

Para Baudrillard (1987), "o desaparecimento das fronteiras entre ficção e realidade atribuiu à mídia não apenas a capacidade de criar fatos, como também a de criar a própria "opinião pública” sobre os fatos que ela mesma gerou”. Para ele, a capacidade de "colonização do imaginário" pelas mídias transformou a própria opinião em simulacro.

Características do pensamento e da ação pós-modernas como o ecletismo, a multidimensionalidade, o pluralismo, a subjetividade, a polissemia e os processos de colagem, encontram na imagem seu principal meio para expressão e comunicação.

Essa nova situação, propriamente pós-moderna, significa uma maior estetização da realidade "que é também, ao mesmo tempo, uma visualização ou colocação em imagens mais completa dessa mesma realidade" (JAMESON, 1995).

No livro "A Condição Pós-Moderna", Harvey (1998) aponta que a pósmodernidade é fruto dos avanços sociais, políticos e culturais da modernidade. Para ele a modernidade é condição para a pós-modernidade. Esta condição não é interpretada como sucessão histórica, mas a partir dos elementos do pós-moderno que já existiam na própria modernidade, que foram acelerados pelos acontecimentos sociais das últimas décadas, como o fim do socialismo real, das metanarrativas e da bipolarização mundial.

O simulacro é a transformação da aparência formal numa espécie de hiperrealidade, possível por meio da repetição e ampliação que os recursos técnicos atualmente existentes fazem muito bem. "Por simulacro designa-se um estado de réplica tão próxima da perfeição que a diferença entre o original e a cópia é quase 
impossível de ser percebida" (HARVEY, 1998, p.196).

Jameson (2004) caracteriza o momento pós-moderno, ou terceiro momento cultural, como uma submersão no universo imagético, que prioriza a estetização e visualização completa da realidade, além de uma "substituição do conceito do estético pelo de intensificação".

O que se vê é um tipo de cultura onde as potencialidades das imagens iniciam um processo de estetização da realidade, acelerando e expandindo a produção e o consumo de imagens propagadas pelas mídias de massa.

A publicidade e as mídias eletrônicas forçam uma padronização cultural que, junto com o pastiche e a aceleração da produção e consumo de "estilos de vida", provocam uma espécie de apagamento do sentido de História.

Dessa forma, o indivíduo pós-moderno estaria vivendo um presente perpétuo, com a consequente perda de referencial histórico, de uma relação de memória ou de identidade. O tempo torna-se efêmero e recortado como o próprio mundo da reprodução das imagens.

Uma das consequências desse raciocínio é que a realidade definida pela cultura pós-moderna autonomiza a própria linguagem, reduzindo os processos simbólicos a um jogo formal ou aleatório de significantes, que utiliza procedimentos como a colagem ou o pastiche como jogos de fragmentos descontextualizados, justapostos conforme considerações subjetivas desprovidas de um sentido histórico a priori.

“... a circulação ou o pastiche de múltiplos estilos nas formas culturais pósmodernas mimetizam a atual tendência da vida social contemporânea para a fragmentação de normas lingüísticas, com cada grupo passando a falar uma curiosa língua particular própria de cada indivíduo tornando-se uma espécie de ilha lingüística, separada de todos os demais" (Jameson, 1986, p.114). 
Por meio de uma análise de base estruturalista, Jameson (1986) demonstrou que objetos culturais devem ser compreendidos de acordo com regras culturais, ou seja, uma análise cuidadosa e detalhada de práticas culturais revelaria que a arte e a cultura estão, inevitavelmente, baseadas em realidades econômicas.

Em uma cultura dominada pelo visual e pela imagem, a própria noção de experiência estética é ou insuficiente ou excessiva, pois agora a experiência estética está por toda a parte e satura a vida social e cotidiana em geral, gerando o colapso da fronteira entre alta arte e cultura popular.

Uma das chaves de análise está nas transformações da dimensão visual na cultura contemporânea, ligada diretamente aos efeitos e prazeres estéticos desenvolvidos na área da produção cinematográfica. A própria história da visão e do visível, estaria relacionada com o desenvolvimento da teoria cinematográfica contemporânea.

Para uma reflexão mais sistematizada, Jameson dividiu a História do Visível nos três seguintes estágios:

\section{Estágio I}

O olhar entendido como tema filosófico por si mesmo, representado pela obra O Ser e o Nada, de Sartre (1944), derivada do existencialismo heideggeriano. Segundo esta reflexão, o olhar estabelece minha imediata relação com as outras pessoas, o que torna a experiência de ser olhado primordial e o meu próprio olhar uma reação secundária.

O olhar é ao mesmo tempo reversível e se torna o medium através do qual se trava a luta hegeliana pelo reconhecimento. O olhar sartriano liga-se à problemática da coisificação (reificação), entendida como o surgimento do objeto, ou conversão do visível no objeto do olhar. 


\section{Estágio II}

Tem como partido uma reflexão a partir de Foucault, levando em consideração a burocratização dos temas da alteridade e da reificação. Aqui o olhar é entendido como instrumento de medida (onde o conhecimento é fonte de poder).

O visível torna-se o olhar burocrático, que mede o Outro e o mundo reificados, em uma inversão do antigo modelo sartriano do olhar, onde o próprio ato de olhar não é mais necessário. O exame e a observação são técnicas com as quais o poder captura o seu sujeito em um mecanismo objetificador.

Em Foucault perde-se a possibilidade de alteridade, de transfiguração do espaço visível da dominação. Na linguagem literária isso se traduz em um tipo trancado em um universo visível, mensurável e sem alternativa.

A dissociação entre o sensório e o anteriormente conceitual, ainda concebida como ativa em algum lugar, de modo impessoal, está por trás da agora desnudada percepção sensível.

A preparação para o terceiro estágio se dá quando o objeto enigmático da arte conceitual é substituído por um objeto tecnológico, em particular pela tecnologia midiática.

Ao definir estas três etapas da teoria da visão no século $X X$, Jameson elege a última, iniciada por volta da década de 80 , como sendo a da sociedade da imagem, que coincide com o processo de sistematização da cultura pós-moderna. Nesse momento, os seres humanos, já expostos ao bombardeio de até mil imagens por dia, vivem e consomem cultura de novas e diferentes maneiras.

\section{Estágio III}

Este estágio foi identificado com a própria pós-modernidade, marcado pela euforia diante da alta tecnologia, que celebra uma certa visão da cultura 
transfigurada pelos computadores e pelo ciberespaço.

A esfera da cultura se expandiu passando a ter os mesmos limites que a sociedade de mercado. O cultural é consumido ao longo da própria vida cotidiana, nas compras, nas atividades profissionais, nas várias formas de lazer frequentemente televisivas, na produção para o mercado e no consumo de produtos mercadológicos.

A estética se abre para o contexto, a partir de então totalmente culturalizado, com ataques críticos dos pós-modernistas às noções antiquadas de "autonomia da obra de arte" e de "autonomia da estética" (pedras angulares filosóficas do modernismo).

Em relação às chamadas "inovações cibernéticas", Jameson (1995) vê como fundamental sua utilização pelo capitalismo enquanto uma forma de se auto-afirmar de maneira simbólica, assumindo a função de "logotipo cultural", ou como uma forma de auto-expressão dessa nova fase do capitalismo e dos próprios tempos atuais.

O que se vê é um tipo de cultura onde as potencialidades e força das imagens inicia um processo de estetização da realidade, acelerando e expandindo a produção e o consumo de imagens propagadas pelas mídias eletrônicas.

Em nosso tempo a tecnologia e a mídia são a base da função epistemológica em que formas tradicionais dão lugar aos experimentos multimídia, ao passo que a fotografia, o cinema e a televisão, começam a convergir na obra de arte visual e a colonizá-la, gerando híbridos high-tech de todos os tipos, das instalações interativas às artes computadorizadas.

Nesse momento, a visibilidade torna-se negativa e universal, sem alternativa utópica, sendo aclamada e festejada por seus próprios méritos. Nesta sociedade da 
imagem são construídas novas relações com o tempo e o espaço, com a experiência existencial e com o consumo cultural.

O espaço social é agora completamente saturado com a cultura da imagem; o espaço utópico da reversão sartriana, as heterotopias foulcaultianas do inclassificado e do inclassificável, foram triunfantemente penetrados e colonizados; do mesmo modo que o autêntico e o não dito, o inexprimível, foram traduzidos para o visível e para o culturalmente familiar. (Jameson, A virada Cultural, pág. 182)

Em uma cultura marcada pela onipresença dos mecanismos de produção e reprodução de imagens e de sua autonomização cada vez maior, o universo da arte e da cultura parecem estar reféns da lógica do marketing e do capital, o que torna importante a realização de reflexões sobre seu espaço de maior representação: o museu contemporâneo.

\subsection{Arte Eletrônica: Uma Trajetória}

O campo de estudo abordado aqui é bastante abrangente e muitas vezes a definição de arte eletrônica é utilizada para se referir a obras que não foram produzidas propriamente por meio de recursos eletrônicos.

Devido à dificuldade de classificação e imprecisão de alguns termos empregados, Arlindo Machado (1996) fez uma análise e formulação conceitual dos movimentos artísticos. Essa separação foi feita sob a perspectiva do contexto brasileiro, analisando a produção que trabalha com arte e tecnologia (www.itaucultural.org.br/aplicexternas/enciclopedia/arttec/index.cfm?fuseaction=det alhe\&cd_verbete=5953).

Ele elencou as seguintes categorias conceituais: Arte-comunicação; Arte em Meios Digitais; Arte Holográfica; Arte na Rede; Hibridismos/Intermídias; Interação 
Arte-Ciência; Música Eletroacústica; Poesia e Novas Tecnologias; Vídeo-Arte e Vídeo-Instalação.

No Brasil, as artes eletrônicas surgem a partir dos anos 1950, com as experiências ópticas de Abraham Palatinik e, já nos anos 1960, se manifesta pelas imagens geradas por computador de Waldemar Cordeiro. Este último, particularmente, foi uma figura de projeção internacional no âmbito da arte computacional, além de ter agregado uma dimensão crítica às obras computadorizadas.

As primeiras experiências com música eletroacústica surgem também nos anos 1950, enquanto a vídeo-arte tem seu início no começo dos anos 1970. A explosão ocorre nos anos 1980, com o aparecimento das obras de telecomunicação (que utilizavam fax, vídeo-texto, slow scan TV e, mais tarde, a Internet), o florescimento da holografia, a ampliação do uso de computadores e a multiplicação de trabalhos nas áreas de multimídia, visualização matemática (fractais, por exemplo), web art e instalações interativas.

Naturalmente, as técnicas, os artifícios e os dispositivos que utiliza o artista para conceber, construir e exibir seus trabalhos não são apenas ferramentas neutras, elas estão impregnadas de significados, eles têm uma história, derivam de condições determinadas.

As artes eletrônicas, como qualquer arte fortemente influenciada pela mediação técnica, colocam o artista diante do desafio de questionar a aceitação incondicional dos desenvolvimentos tecnológicos, evitando assim que sua obra resulte simplesmente num endosso dos objetivos de produtividade da sociedade tecnológica. 


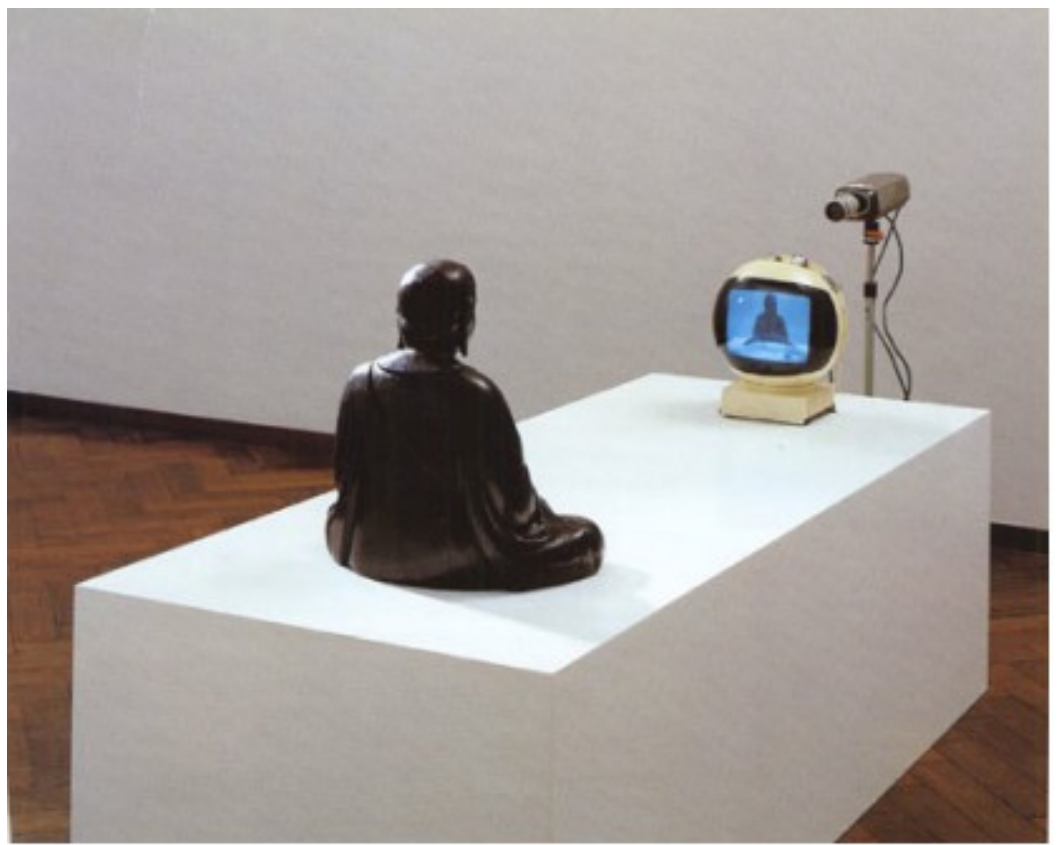

Figura 10. PAIK, Nam June. TV Buda, 1974.

Não há uma precisão exata sobre quando começam oficialmente as produções de arte eletrônica. Mesmo antes do videotape estar disponível para intervenção artística, alguns criadores como o alemão Wolf Vostell e o coreano Nam June Paik já produziam arte alterando os circuitos eletrônicos de aparelhos de televisão ou distorcendo suas imagens com a ajuda de ímãs e foram os primeiros a trabalhar os conceitos de arte e imagem utilizando o vídeotape e a tv (figura 10).

A vídeo-arte surge oficialmente no começo dos anos 60, com a disponibilização comercial do Portapack (gravador portátil de videotape) e graças, sobretudo, ao gênio artístico de Paik. Há ainda nomes pioneiros como o do húngaro-americano Ernie Kovacs e do francês Jean-Christophe Averty, que introduziram na televisão a autoria e a criação artística, além de terem sido os primeiros a explorar amplamente a linguagem do novo meio, motivo que levou alguns autores a considerá-los os verdadeiros criadores da vídeo-arte, antes mesmo de Vostel e Paik. 
Um brasileiro de grande importância é Artur Omar, artista multimídia que iniciou seus trabalhos na década de 1980 explorando a combinação de diferentes mídias, principalmente em videoinstalações. Ele explora o cinema, vídeo, fotografia, música, poesia, desenho, além de produzir ensaios e reflexões sobre os processos de formação e significação da imagem.

Sua produção contemporânea utiliza sons e imagens com o objetivo de provocar a imersão do espectador em um universo de provocadoras metáforas poéticas (figura 11).

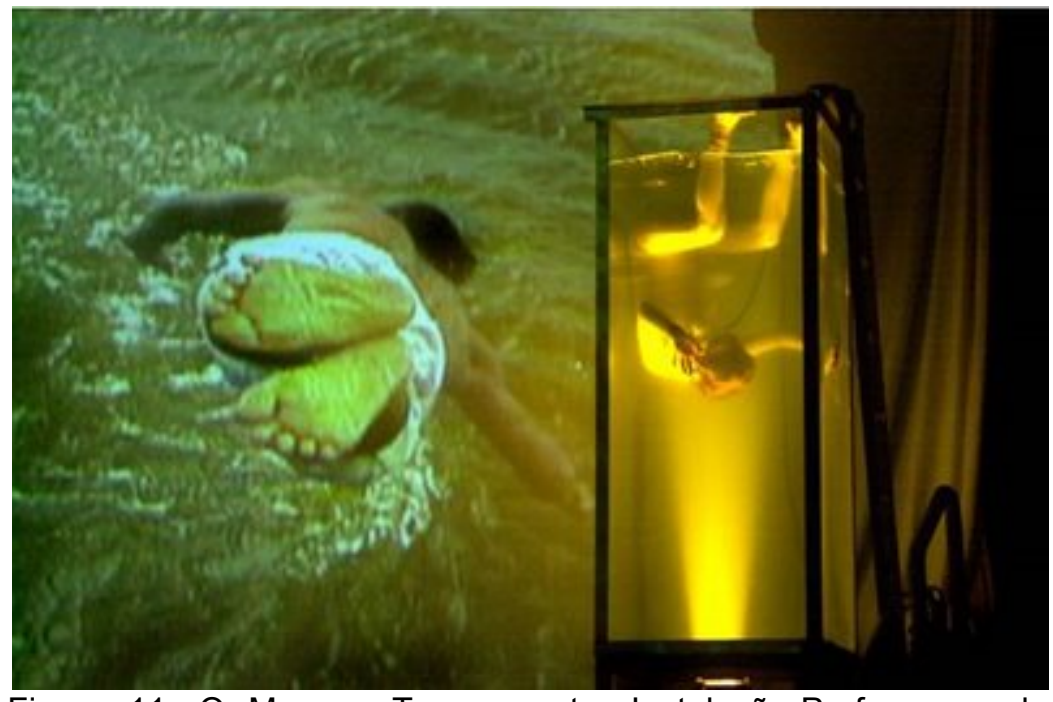

Figura 11. O Macaco Transparente, Instalação-Perfomance de Arthur Omar e Bianca Ramoneda, 2004.

Recursos informáticos para a produção, manipulação e exibição de imagens já estavam disponíveis na década de 50 , graças ao surgimento de monitores capazes de exibir gráficos e de plotters para imprimi-los. Embora esses recursos tenham sido implementados prioritariamente para a visualização matemática e científica, muito cedo alguns artistas souberam tirar proveito deles para a exploração de uma nova visualidade dentro das artes plásticas.

Os primeiros trabalhos artísticos produzidos com o auxílio de computadores 
ainda utilizavam máquinas analógicas para a geração de imagens, osciloscópios de raios catódicos para exibi-las e películas cinematográficas para registrá-las.

Em 1952, Ben F. Laposky, nos EUA, e Herbert W. Franke, na Áustria, conceberam, respectivamente, suas Abstrações Eletrônicas e seus Oscilogramas, consideradas as primeiras obras de computer art produzidas. Mas foi a partir de 1962, com o desenvolvimento, por Ivan Sutherland, de um completo sistema interativo de desenho por computador, o Sketchpad, que começaram a aparecer os primeiros trabalhos artísticos produzidos inteiramente em computadores digitais.

É preciso considerar ainda que, embora a expressão arte eletrônica seja mais genericamente utilizada para referir-se a trabalhos realizados no âmbito das artes visuais, num sentido mais amplo ela poderia abarcar também a música, que foi a primeira arte a explorar recursos eletrônicos. A música concreta, que utilizava técnicas de edição eletrônica, foi criada na França em 1948, por Pierre Schaeffer, enquanto a música eletroacústica surgiu por volta de 1950 com Stockhausen na Alemanha e Pierre Boulez na França.

A formação dos primeiros grupos dedicados à arte e tecnologia e as instituições culturais dedicadas à produção e veiculação de arte digital levaram cerca de dez anos para se deslocarem do cenário underground para o espaço de destaque que assumiram anos depois.

Apesar do surgimento de alguns congressos e encontros de artistas que trabalhavam com sistemas computacionais terem surgido a partir do final da década de 1970, o campo de pesquisa e produção com novas mídias começou realmente a tomar corpo somente no final da década de 1980 (MANOVICH, 2002, p.13).

Os pioneiros que surgiram no final da década de setenta foram o SIGGRAPH, 
nos Estados Unidos e o Ars Electronica na Áustria. Esses movimentos ganharam mais força no final da década de noventa com o surgimento de instituições voltadas à produção e apoio às novas mídias, principalmente em território europeu, com os institutos ZKM em Karlsruhe (1989), o New Media Institute em Frankfurt (1990) e o ISEA (Inter-Society for the Electronic Arts) na Holanda (1990).

Os dois artistas que mais se destacaram no trabalho de coordenação desses institutos foram Peter Weibel (New Media Institute) e Jeffrey Shaw (ZKM).

Durante os anos oitenta, com o surgimento das tecnologias digitais e o desenvolvimento de linguagens gráficas geradas ou manipuladas digitalmente, o campo das artes foi se apropriando dos novos meios e desenvolvendo um novo tipo de arte, mais interativo e com novos suportes de exibição.

Este tipo de arte esteve diretamente relacionado à criação de muitos institutos artísticos que se dedicam à pesquisa estética e conceitual da arte por meio dos novos paradigmas da sociedade da informação.

As artes e a tecnologia sempre mantiveram uma aproximação entre suas formas de ver e compreender o universo, operando através de leituras e significações que o sujeito projeta sobre a natureza. Ambas materializam um campo de reflexão que é a objetivação do sujeito em sua realidade exterior.

Na década de 90 começaram também a surgir atividades relacionadas às novas mídias no Japão, como o Intercommunication Center em Tóquio. Durante a década de 90 Japão e Europa se consolidaram como os principais centros de excelência para se assistir e participar dos círculos de discussões sobre os novos campos das artes eletrônicas e digitais.

No Brasil podemos destacar, no final dos anos 1990, as experiências com sky art de Wagner Garcia, de tele robótica de Eduardo Kac e as primeiras obras de 
fusão da eletrônica com a biologia (próteses corporais, vida artificial, arte transgênica), um campo que está gerando muita polêmica e discussões sobre os limites da tecnologia em manipular a vida.

Alguns festivais que se consagraram nessa época foram o ISEA (Inter Society for the Eletronic Arts), Ars Electronica e DEAF (Dutch Eletronic Art Festival), que se tornaram espaços abertos às novas produções. Nesses festivais é exibida uma variedade de obras que inclui instalações interativas, músicos que utilizam sistemas computacionais na criação e produção de sons, coreógrafos que interagem com computadores e, após a chegada da Internet, os artistas que desenvolvem seu trabalho explorando as potencialidades das comunicações em redes.

Os Estados Unidos, apesar de todo o investimento em pesquisa e desenvolvimento tecnológico, foi o país que menos participou das formulações críticas frente às novas tecnologias, principalmente em seu próprio território. Houve um distanciamento crítico entre europeus e americanos que fica evidente quando se observa a quantidade de institutos e centros de pesquisa criados e financiados pelos governos europeus.

Isso pode ser compreendido como uma espécie de cegueira criada pela forte onipresença da tecnologia no cotidiano dos norte-americanos. Devido à rápida assimilação das tecnologias que os cercam, eles a recebem como parte natural de seu cotidiano.

Nos países em que a velocidade de desenvolvimento tecnológico foi menor, houve um maior tempo para a reflexão durante o processo de produção e recepção de novas tecnologias; além disso, há um fator cultural na Europa, que se manifesta como um certo ceticismo frente à aceitação cega e incondicional das novas tecnologias. 
Outro fato importante para a falta de engajamento da sociedade norteamericana com as artes digitais foi o pequeno apoio público recebido pelas artes. $\mathrm{Na}$ Europa, Japão e Austrália, houve um esforço direto do governo em promover atividades e exibições direcionadas às novas mídias, o que não ocorreu na América.

Esse mercado de cultura de massas foi responsável por muito investimento financeiro e experimentação com as novas mídias, mas ofereceu como resultado produtos tecnológicos que não contribuíam para uma reflexão crítica ou aprofundamento de questões de investigação puramente teóricas ou artísticas.

A indústria cultural americana teve grande contribuição pela introdução da Inteligência Artificial em jogos para computador, compartilhamento de arquivos de mídia pela rede, animações e vídeo, ambientes 3D via rede, modelagem e animações 3D, CD ROMs, DVDs e uma grande quantidade de produtos e formas de entretenimento.

Devido à essa forma de produção, os EUA se tornaram os mais conservadores no cenário crítico das artes digitais, fato que pode ser traduzido a partir da distância existente entre a esfera da produção artística e os interesses comerciais impostos pelo mercado.

Estas características conferem ao objeto artístico uma identidade ou originalidade que estabelecem uma relação do espectador com o momento de criação da obra.

As novas mídias, com seu poder de reprodução em massa e rápida distribuição em escala global alteraram a forma de percepção das obras de arte, destituindo-as da presença da aura.

As novas mídias fazem parte de um modo de produção onde a potencialidade 
de reprodução das obras rompe de certa maneira com a ideia romantizada do trabalho do artista, dissolvendo as características únicas de uma peça e permitindo que os trabalhos artísticos assumam uma diversidade de formas e suportes que possibilitam sua distribuição massiva.

A ideia de interatividade altera profundamente a relação entre obra e espectador, a assimilação da obra passa a ser produto de uma troca de informações que a altera incessantemente.

O usuário se torna um coautor da obra no momento em que a transforma e recria durante o processo de fruição do objeto artístico. Existem ainda trabalhos colaborativos, que são desenvolvidos utilizando redes de comunicação para a distribuição e veiculação da obra, tornando-a onipresente, acessível desde qualquer ponto do planeta através de um ponto de conexão à Internet.

Os espaços de exibição para novas mídias pressupõem um forte investimento em equipamentos e infraestrutura tecnológica, algo que também só foi possível em países europeus devido aos interesses e apoio de fundações federais e regionais, que permitiram a montagem de sofisticadas instalações interativas para a realização de pesquisas inovadoras no campo das artes digitais.

Nos EUA, o cenário artístico foi centrado na chamada "net-art", que não demanda muitos recursos além de um computador conectado à rede. Ao final dos anos 90 essa situação foi se transformando devido à algumas instituições, principalmente educacionais, como universidades e escolas de arte, principalmente na costa oeste, que começaram a se interessar e criar programas especiais para o incentivo à produção e estudo de mídias e design digital (BENJAMIN, 1985).

A partir do ano 2000, alguns museus americanos começam a abrir espaços dedicados às produções de novas mídias e apoiar o desenvolvimento da net art. 
Alguns museus como o Walker Art Center (Minneapolis, Minnesota), Whitney Museum in New York e San Francisco Museum of Modern Art (SFMOMA), criaram espaços específicos para a exposição de arte digital.

Essa abertura foi tardia em relação às mostras e exibições que estavam sendo realizadas na Europa, como o Ars Electronica Center em Linz, o Intercommunication Center em Tóquio, ou ZKM na Alemanha.

Posteriormente, significativas instituições acadêmicas como o Instituto para Estudos Avançados de Princeton, fundações privadas como a Fundação Rockefeller, além da publicação de livros e coleções sobre novas mídias publicadas por editoras respeitadas, como a MIT Press, irão publicar as discussões e a produção de arte digital para um público menos restrito, proporcionando maior visibilidade ao tema.

Em apenas uma década, toda aquela produção que circulava perifericamente foi absorvida pelos meios acadêmicos e aceita enquanto campo artístico com legitimidade própria. Aquele movimento que havia surgido de um grupo restrito de indivíduos ganhou forma, coesão e recebeu apoio e suporte de instituições públicas e privadas.

Assim como os movimentos artísticos de vanguarda da era moderna, que utilizaram recursos oferecidos pela fotografia para compreender o comportamento da luz, é coerente que os artistas hoje explorem os meios oferecidos pelas novas tecnologias, como o vídeo, o computador, a Internet, os programas de modelagem 3D, processamento e edição de imagem e até mesmo a engenharia genética para expressar suas reflexões artísticas e valores estéticos.

Cada vez mais os artistas utilizam o computador para construir suas imagens, músicas, textos e instalações. O vídeo se tornou quase onipresente e a interação 
um denominador comum das produções.

Os artistas rapidamente incorporaram as novas mídias e a utilização de novas interfaces estimulou a pesquisa e experimentação em busca de novos caminhos para a arte da sociedade da informação. A hibridização dos meios é a resposta mais recorrente e demonstra a preocupação em envolver todos os sentidos e promover uma experiência repleta de sensações.

Esta sobrecarga de estímulos e a relação de interação e comunicação com a obra transforma completamente o comportamento e os processos de percepção, reflexão e aprendizagem que a arte pode estimular.

\subsection{Os primeiros institutos de arte e tecnologia europeus}

\subsubsection{ISEA (Inter-Society for the Electronic Arts)}

O ISEA é uma organização internacional não comercial cujos colaboradores consistem em indivíduos e instituições envolvidas no trabalho de questões relacionadas aos aspectos criativos, teóricos e tecnológicos das artes eletrônicas.

Ele busca estabelecer e organizar trocas interdisciplinares entre vários discursos acadêmicos, promovendo o intercâmbio cultural entre artistas e instituições que trabalham com arte, ciência e novas tecnologias.

O ISEA distribui uma publicação impressa e disponibiliza arquivos on-line com informações sobre a instituição, projetos, exposições e artistas. Realiza também regularmente o Simpósio Internacional de Arte Eletrônica, que reúne uma grande variedade de pessoas ligadas às questões da arte, ciência e tecnologia. 
Os simpósios começaram a ser organizados em 1988, com o intuito de oferecer suporte à criação e manutenção de uma rede de comunicação entre organizações e indivíduos que participam ativamente da produção de arte eletrônica.

Esta rede de trabalho tomou a forma de uma instituição e foi oficialmente fundada em 1990, na Holanda, com o nome ISEA (Inter-Society for the Electronic Arts). Os membros do ISEA reuniram diferentes referências culturais de aproximação e questionamento das novas tecnologias. Até o ano de 1996, a organização estava sediada na Holanda; de 1996 a 2001, o ISEA foi transferido para Montreal, no Canadá; em 2001 retorna à Holanda, onde permanece até hoje.

Esta sociedade internacional é responsável por supervisionar a organização do simpósio em cada uma das cidades escolhidas, com a intenção de assegurar a continuidade da identidade do evento e sua qualidade de organização, trabalhando em conjunto com a organização local.

\subsubsection{ZKM (Zentrum für Kunst und Medientechnologie)}

Em 1986 foi criado um grupo com um projeto coeso, formado por políticos locais e representantes do meio acadêmico em Karlsruhe, que iniciou os trabalhos de fomento à criação de novas instituições com foco na união das áreas da arte e da ciência. Em um documento intitulado "Concept 88", eles descreveram sua visão sobre como unir as artes e as novas mídias tanto na esfera teórica como na prática.

Em 1989 foi criado seu primeiro conselho e eleito o professor Heinrich Klotz como diretor, iniciando o processo de constituição do Centro de Arte e Mídia (ZKM). Originalmente o Centro foi instalado em uma edificação ao sul de Karlsruhe, próximo à estação central de trem da cidade. 
Havia um plano de construção de um edifício novo, com projeto de Rem Kohlhaas, mas o orçamento estava muito acima do previsto. Foi escolhido então um edifício histórico, uma antiga fábrica de munições, que se tornou a sede do ZKM. O escritório de arquitetura Schweger \& Partner foi o responsável pelo projeto de reconstrução e renovação, convertendo a estrutura de uma antiga edificação para a utilização e apresentação de avançadas tecnologias e experimentos artísticos.

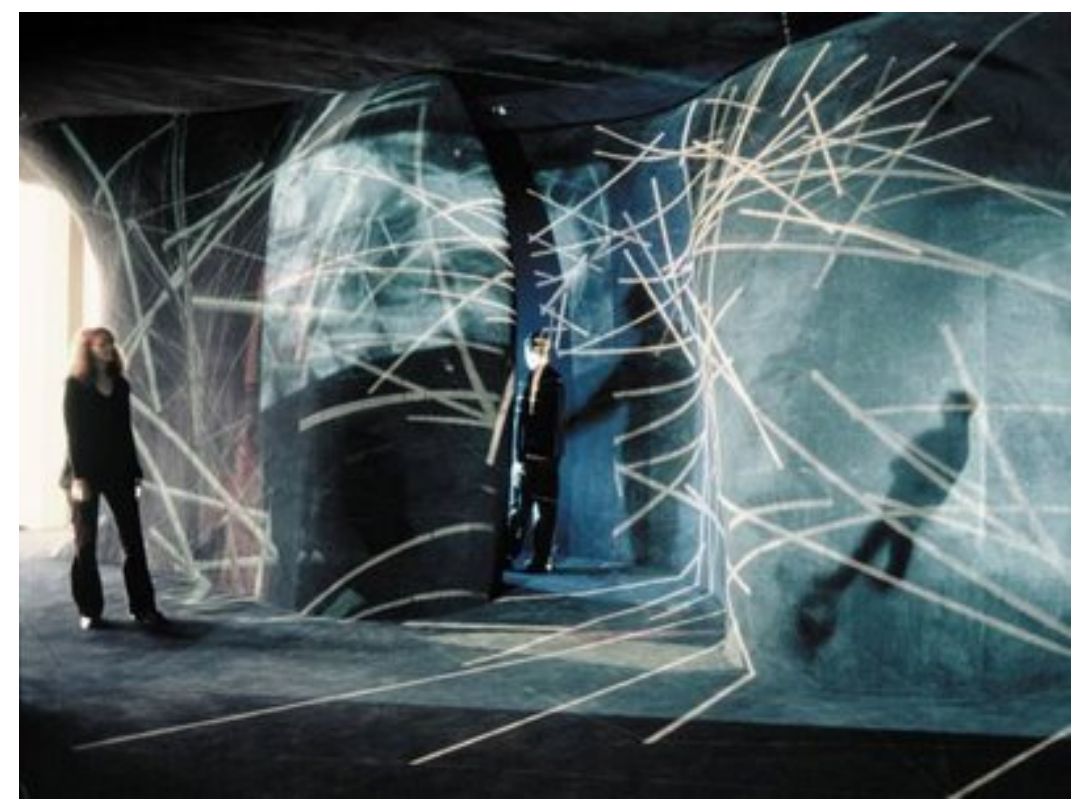

Figura 12. SHAW, Jeffrey. Web of Life, 2002.

Instalação produzida pelo instituto ZKM, que explora as relações entre arte e ciência utilizando as teorias dos sistemas para refletir sobre processos da natureza, economia e sociedade.

Nas primeiras fases de sua construção, o Centro estava espalhado por toda a cidade, apesar disso, eventos como ZKM in the Factor e o Festival de Arte e Mídia Multimediale com o Siemens Media Arts Award, deram oportunidade ao público o contato com experiências proporcionadas pelos trabalhos do Centro, mesmo antes de abrir suas portas em 1997 (figura 12).

O ZKM, enquanto instituição cultural, ocupa uma posição de destaque no 
cenário internacional, buscando acompanhar os rápidos desenvolvimentos em tecnologias da informação e as transformações das estruturas sociais. Ele atua nas áreas de produção e pesquisa, exibições e eventos, coordenação e documentação.

Para o desenvolvimento de projetos interdisciplinares e promoção de colaborações internacionais, o ZKM tem empregado recursos no Museum for Contemporary Art, no Media Museum, no Institute for Visual Media, no Institute for Music and Acoustics, e em mais três departamentos: o Institute for Basic Research, o Institute for Media and Economics, e o Filminstitute.

Sob a direção do Prof. Peter Weibel desde 1999, o ZKM desenvolve pesquisas em novas mídias buscando abordar questões teóricas e práticas, testando seu potencial em desenvolvimentos para usos domésticos, promovendo debates sobre as formas que as novas tecnologias se manifestam em nossas vidas e as transformações que provocam sobre a sociedade. Trabalhando em conjunto com a State Academy for Design e outras instituições, o ZKM oferece também espaço para fóruns de debate sobre ciência, arte, política e economia.

Em seu edifício oferece eventos e passeios, exibições públicas e acesso aos serviços da Mediateca. O Centro se configura como um espaço para a experimentação e discussão, com o intuito de participar ativamente em trabalhos que reflitam sobre os caminhos para o futuro, fomentando o debate sobre um uso mais sensível e positivo das tecnologias.

\subsubsection{MEDIA LAB}

O Media Lab foi concebido em 1980 pelo seu conhecido pesquisador Nicholas Negroponte, em parceria com o grande cientista e presidente do MIT Jerome Wiesner. O laboratório abriu suas portas em 1985, funcionando no edifício 
desenhado pelo arquiteto I. M. Pei.

Em sua primeira década, o Media Lab foi o pioneiro em muitas das tecnologias que tornaram possível a "revolução digital" e potencializaram as formas de expressão humanas. O laboratório desenvolveu pesquisas inovadoras nas áreas de cognição e aprendizado, música eletrônica e holografia.

Durante a década seguinte, o laboratório expandiu os limites computacionais, levando os bits para o mundo real, físico. As pesquisas se concentram em tecnologias de interface com o corpo humano, vestimentas computacionais, protocolos de transmissão de dados wireless, sensores e atuadores, novas formas de expressão artística e novas metodologias de ensino infantil.

Na última década, o Media Lab direcionou suas pesquisas no campo da "adaptabilidade humana", trabalhando com questões desde iniciativas de tratamento para portadores do mal de Alzheimer, até robôs pré-programados que podem monitorar a saúde de uma criança ou idoso, e até mesmo desenvolvendo próteses inteligentes que possam auxiliar os descapacitados a superar suas dificuldades.

\subsubsection{ARS Electronica FutureLab}

O FutureLab funciona como plataforma de trabalho interdisciplinar para projetos que envolvem negócios, artes, ciência e entretenimento. Inovações da área de negócios são desenvolvidas ao lado de produções artísticas, vídeos, animações e projetos em rede. O laboratório/estúdio é o mais bem equipado da Áustria para projetos de mídia, com destaque para a realidade virtual.

O Futurelab trabalha desde a sua formação, com o foco na tensão e interação 
que acontece na confluência entre arte, tecnologia e sociedade, formulando e implementando manifestações artísticas que questionem e expressem essas interações.

Os artistas desenvolvem seu trabalho em uma mistura de atelier de criação e laboratório de pesquisas e desenvolvimento, unindo os aspectos analítico e experimentais de um laboratório com a arte e criatividade de um atelier. Neste espaço acontecem atividades transdisciplinares que são continuamente repensadas e reconfiguradas de acordo com as demandas dos trabalhos em desenvolvimento.

São $750 \mathrm{~m}^{2}$ de área disponíveis para os cerca de 50 artistas e pesquisadores envolvidos na concepção, planejamento e realização dos projetos com colaboradores e clientes em todo o mundo. Entre os profissionais que participam dos trabalhos existem artistas programadores, cientistas da computação, físicos, designers, arquitetos, desenvolvedores de games, engenheiros de telemática, sociólogos, historiadores da arte e estudantes da área de estudos culturais e comunicação.

O instituto tem obtido sucesso ao expandir sua atuação no desenvolvimento de projetos encomendados por clientes que utilizam estas tecnologias em instalações de cultura e educação ou mesmo em aplicações comerciais. Ao mesmo tempo em que as produções artísticas, a arquitetura também expressa as transformações da percepção social do uso das tecnologias e dos modos de mediar o encontro do público com o conteúdo. 


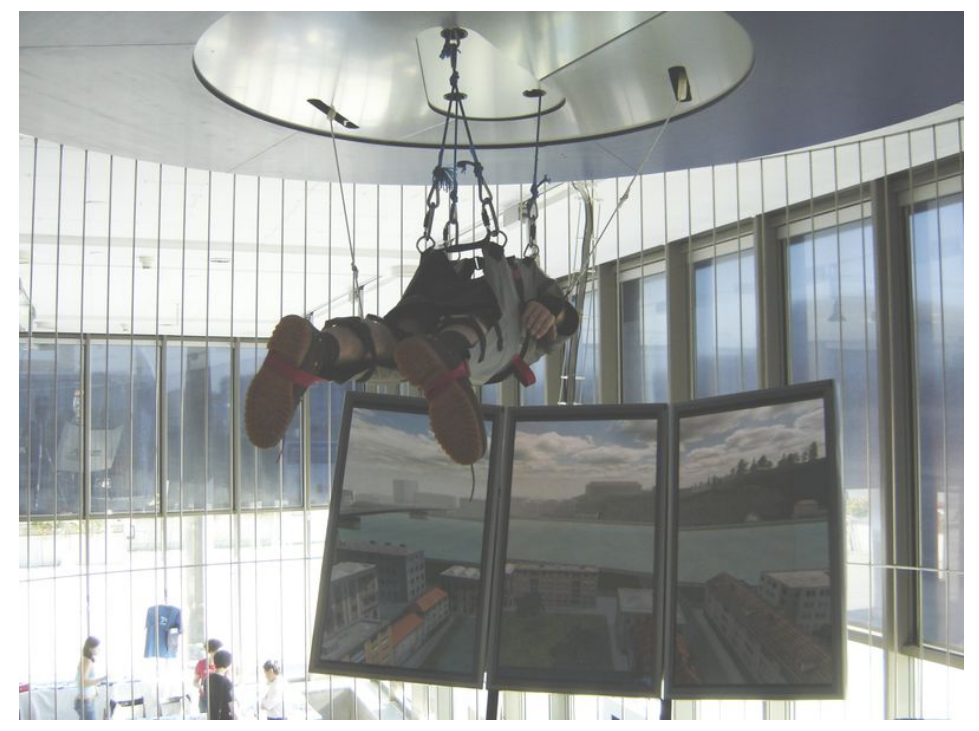

Figura 13.Visitante suspenso por equipamento que permite a navegação sobre uma cidade modelada em Realidade Virtual no edifício do Ars Electronica em Linz, Áustria. Imagem: Erik Möller, 2005.

$\mathrm{Na}$ área de exibições, o laboratório se concentra na concepção, projeto e execução de cenários e espaços expositivos para mediar o contato do público com a informação e dar suporte aos processos mediados pelo uso de arte multimídia. Alguns trabalhos são realizados sob encomenda e dependem das demandas de cada cliente, que são analisadas e planejadas para serem implementadas na forma de uma exibição interativa.

A maioria dos trabalhos desenvolvidos pelo Ars Electronica Futurelab envolve o desenho de interfaces, ou Interaction Design, focadas na interpretação da interação entre homens e máquinas e no próprio processo de mediação com elas, levando à adaptação e criação de novas tecnologias e equipamentos (figura 13). 


\section{Capítulo 4 - Museu e Tecnologia}

O domínio da arquitetura foi transformado pelo avanço das pesquisas em interatividade, vestuário computacional, conectividade móvel, design centrado nas pessoas, sistemas de vigilância, tecnologias RFID (Identificacão por Radiofrequência) e computação ubíqua. Estas tecnologias alteram nosso entendimento do espaço e mudam a forma como nos relacionamos.

A arquitetura se tornou dinâmica, comunicativa, reativa e amigável, utilizando para isso os sistemas cibernéticos de controle e automação aliados às tecnologias de informação e comunicação que aumentam os potenciais de aplicação social das novas tecnologias.

O museu não é formado apenas pelo seu invólucro arquitetônico, mas uma instituição que envolve várias áreas do conhecimento e um grupo coordenado de profissionais para gerir este espaço. É preciso um corpo técnico especializado e uma curadoria coerente com as propostas institucionais e que planeje as estratégias e conceitos para organizar as exposições.

O trabalho nunca é realizado por apenas uma pessoa e todo o processo necessita da participação de uma equipe interdisciplinar que trabalhe de forma integrada, agregando conhecimentos e experiências. Muitas vezes o conceito está formulado, mas as formas de produção e materialização das ideias são definidas conjuntamente.

Um dos aspectos mais interessantes é o funcionamento integrado da arquitetura com as TIC's e seu potencial de transformação cultural e social por meio da troca de informações dinâmica e sistêmica entre arquitetura e sociedade. Existem novos caminhos sendo trilhados pelos artistas e curadores 
contemporâneos para compreender as relações entre os espaços de exposição, suas formas de aproximação com o público e estratégias de organização espacial.

Normalmente, as exposições são pensadas como um percurso associado à sucessão de informações e eventos que desenha a narrativa. Os modelos tradicionais traçam um percurso único, que conduz o espectador através da história a ser contada. Existe muitas vezes um discurso linear a ser "percorrido", que não oferece alternativas ou possibilidades de descontinuidade ou criação de um discurso não-linear.

Por outro lado, existem modelos de organização curatoriais mais abertos, que permitem uma fruição diferente e possibilitam a percepção do espaço de um modo menos linear e mais livre e subjetivo, o que permite a construção de diversas narrativas diferentes. Sem dúvida, a relação entre curadores e artistas é retroalimentada e ora criam situações de tensão, ora estabelecem um diálogo coeso e harmonioso.

Em alguns casos, as obras são dispostas em um espaço mais integrado, com caminhos intercomunicantes e percursos alternativos, dispondo os objetos com uma hierarquia mais horizontal. É como se fossem criados polos de atratividade, que vão conduzindo o púbico de acordo com a própria dinâmica da exposição e de seus visitantes.

A tecnologia dos dispositivos móveis multimídia está contribuindo em outro nível, fornecendo informações em tempo real durante a visita ao museu. Por meio de sensores de localização, o conteúdo pode ser ativado a partir da posição da pessoa no edifício, servindo como um guia virtual e oferecendo uma nova gama de aplicações no acesso aos museus.

Os smartphones também possuem diversos recursos que podem servir de 
matéria para a construção de conteúdo e funcionar como chave para as interações no espaço do museu. Com os diversos sensores, conectividade e poder de processamento, além da possibilidade de captura de imagens, vídeos e sons, os celulares estão se tornando onipresentes e podem fornecer usos instigantes e inspiradores.

O conceito de interface pode ser ampliado a tudo o que nos relacionamos em nosso cotidiano, desde nossas roupas até a cidade que percorremos, sempre existe algo intermediando nossa relação com o mundo. Em última instância, nossos sentidos são um tipo de interface entre o mundo sensível e nossa mente e codificam os sinais externos para uma linguagem que nosso cérebro seja capaz de interpretar.

O entendimento do corpo humano e suas funções e mecanismos reguladores, levou à criação dos sistemas computacionais baseados nessa forma de funcionamento. Os componentes principais que integram os computadores são análogos aos órgãos biológicos do homem, como por exemplo, a voz é substituída por um alto falante, o ouvido por um microfone, os olhos por câmeras e o cérebro, por memória e processador.

No entanto, o mais importante é a comunicação, ou troca de informação, entre os sistemas, devido ao fato de que a conectividade torna possível uma interação que altera as relações de espaço e tempo.

Obviamente, essa nova forma de lidar com a informação exige mecanismos de busca e seleção mais inteligentes e o desenvolvimento de interfaces mais intuitivas para agilizar o processo e tornar o trabalho mais eficiente.

Os primeiros computadores pessoais projetados na década de 1970 iniciaram esta revolução com a utilização do mouse e de uma interface gráfica baseada na 
criação de múltiplas janelas.

O kit composto por teclado, mouse, tela e sistema de som se tornou padrão para os computadores pessoais e possibilitou a disseminação e uso por praticamente qualquer pessoa. O modo simples e intuitivo desta interface foi assimilado rapidamente pelas pessoas e se tornou uma ferramenta indispensável tanto para o trabalho como para o lazer.

Com a miniaturização dos dispositivos, os computadores se tornaram portáteis mas a interface continuou praticamente a mesma, sendo o mouse substituído pelo touchpad (superfície sensível ao toque, utilizada para o deslocamento do cursor).

No entanto, com o recente crescimento do mercado de tablets, uma nova forma de interação está sendo construída. Com isso, o mouse e o teclado foram dispensados pela utilização de uma tela sensível ao toque (touchscreen), que assume a função de interface para a leitura e entrada de dados.

Este tipo de obra de arte (site especific art) passa por modificações e adaptações de acordo com a situação e local a ser utilizado, o que às vezes altera a própria percepção da obra. Em alguns casos, como acontece com a obra Dune, do artista holandês Daan Roosegaard (www.studioroosegaard.net/projects), ela foi montada tanto em espaços fechados e controlados de museus e galerias, como em praças, ruas e corredores de estações de metrô.

Roosegaard criou seu próprio laboratório em Rotterdam, onde desenvolve projetos de grande escala, integrando tecnologia, arte e arquitetura para serem apresentadas principalmente em espaços públicos.

Segundo o artista, o trabalho de seu estúdio explora a relação dinâmica entre arquitetura, pessoas e novas mídias. Nesta pesquisa, as esculturas são colisões 
entre a tecnologia e o corpo humano materializadas. Por meio do uso de novas mídias, as esculturas acionam os sentidos humanos para criar uma ligação com seu ambiente.

A obra Dune (2006), é um tipo de instalação formada por um sistema modular de hastes flexíveis presas ao chão, que podem ser dispostas ao longo de um caminho ou em diferentes configurações (figura 14). As hastes possuem uma altura pouco abaixo de um metro e se assemelham a estruturas de plantas, como se fossem massas arbustivas, que reagem aos sons e movimentos das pessoas.

A obra pode ser ampliada e adaptada conforme a situação espacial em que for inserida, pois os elementos podem ser rearranjados de diferentes maneiras. Existe também um desenvolvimento constante das tecnologias utilizadas e seus sistemas de controle, o que leva à edição do trabalho e lançamento de novas versões da obra. Este conceito é o mesmo da engenharia de desenvolvimento de softwares, que adota um processo ininterrupto de aperfeiçoamento e incorporação de novas tecnologias à uma mesma plataforma.

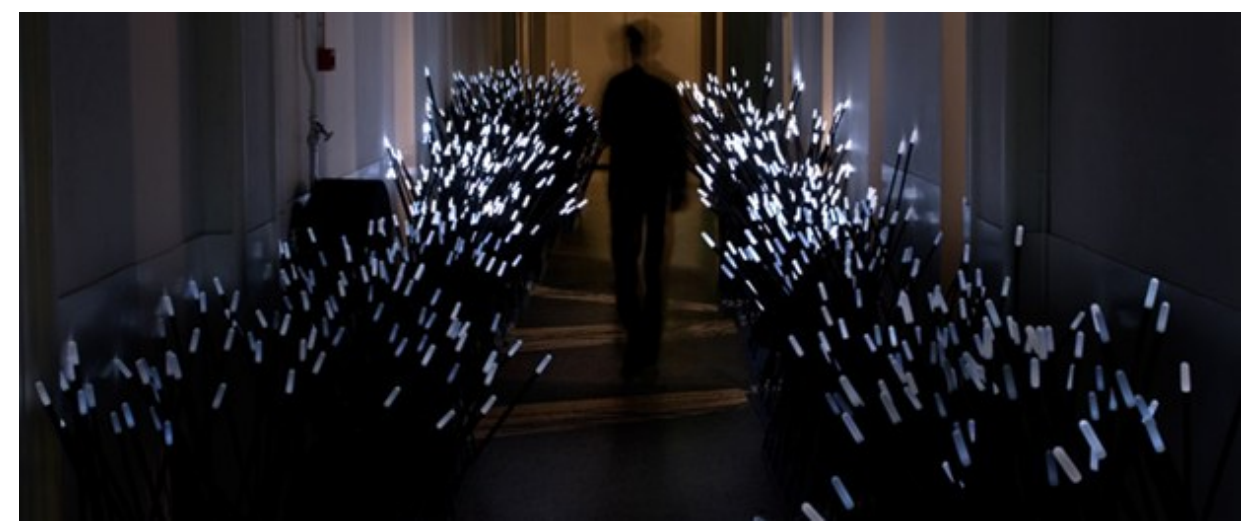

Figura 14. Obra Dune (2006), organizada como corredor de passagem em uma galeria de exposições.

Uma das consequências desta abordagem é que o que se mantém é o 
conceito (forma), enquanto os materiais e tecnologias são a matéria (aquilo que é mutável). Assim, a obra Dune, por exemplo, está em sua versão 4.2, o que demonstra que a obra está submetida a um processo de desenvolvimento constante.

Com isso, a obra adquire certa flexibilidade, já que após o conceito ser criado, os materiais utilizados podem ser melhorados e aperfeiçoados conforme o desejo de seus desenvolvedores. Além disso, existe a possibilidade de criar obras como plataformas abertas, pensadas para serem customizadas e adaptadas em diferentes situações e finalidades.

Um dos maiores desafios que os curadores estão passando em relação à interatividade é a propriedade tátil dos objetos artísticos, que permitem ao público tocá-los para acessar as informações. Atualmente as exposições têm que considerar a participação do visitante, já que a interatividade coloca as pessoas como parte da obra, ocupando e partilhando o espaço. Em algumas obras, as pessoas se tornam objeto de contemplação, desempenhando um papel fundamental para a apreensão do significado pleno da obra. O contato acontece em dois momentos: observando as outras pessoas e sendo observado.

O espaço museográfico tradicional é pensado com lógica diferente, já que as peças estão ali apenas para serem observadas, longe do alcance das mãos dos visitantes. Faixas de segurança, cercas, vitrines e vigias estão presentes para impedir qualquer tentativa de contato físico com a arte.

Essas obras devem ser preservadas da ação do tempo e expostas adequadamente, com o objetivo de manter o patrimônio cultural para o conhecimento das futuras gerações. No entanto, as obras de arte interativas têm uma dinâmica inversa e apresentam uma problemática diferente a ser enfrentada 
pelo museu.

Existe também uma questão relacionada aos costumes, já que a cultura dominante criou um comportamento excessivamente passivo, direcionado apenas à admiração contemplativa dos objetos de arte. Alguns movimentos artísticos e culturais como os Situacionistas (1957) e Fluxus (1961) propuseram a participação das pessoas em suas obras. A atitude de afastada contemplação é em parte determinada pela ideia de que se vai ao museu justamente para ver uma seleção de obras de alta qualidade.

Geralmente a interação exige contato físico ou uma postura ativa para que a obra aconteça, o que incomoda alguns visitantes pela ruptura com os valores e convenções tradicionalmente cultivados pelo espaço da arte. A interação com os objetos fica geralmente restrita aos ambientes infantis e de aprendizagem, onde a manipulação dos materiais tem intenção lúdica e didática.

Interatividade não é um valor em si ou uma propriedade que determine a qualidade de uma obra, mas um dado da prática artística que deve ser trabalhado de forma coerente e criteriosa. De fato, realizamos atividades interativas a todo momento, quando conversamos com alguém, quando dirigimos um carro e em tantas outras situações banais do cotidiano. Portanto, a interatividade deve ser entendida como mais uma ferramenta à disposição do artista, para ser utilizada no momento apropriado.

$\mathrm{Na}$ sociedade do espetáculo, a indústria do entretenimento, com avançados recursos tecnológicos e digitais, tem auxiliado a criar uma demanda insaciável por entretenimento e novidades tecnológicas (como o renascimento da tecnologia 3D que vemos atualmente). Por esse motivo, a media art e a arte interativa receberam uma pressão semelhante, com o objetivo de melhorar sua capacidade de 
entretenimento.

A interatividade pode também ser utilizada na esfera curatorial, como aparece no projeto artístico Your Show Here (http://www.sgp7.net/index2007.shtm?ID=25\&k=works), criado por Tara McDowell e Letha Wilson (coordenadores do projeto), Chris Pennock (design de software), Nina Dinoff (design gráfico) e Scott Paterson (arquitetura da informação). Nessa obra, os visitantes podem acessar um banco de imagens, filtrando os resultados de acordo com o nome do artista, tipo de material, data e palavra-chave. Depois é possível visualizar a exposição, com as obras projetadas em tamanho real, que permanece ali até que outra pessoa organize sua própria exposição.

A obra explora o conceito de "curadoria pública" para propor uma forma alternativa de apresentar e visualizar a exposição que promove a participação e defende que a arte pode adquirir diferentes significados a cada reconfiguração. Esta abordagem permite que a exposição reflita as vontades, gostos e interesses do público.

O trabalho do curador está se diluindo e seu papel direcionado à mediação entre os artistas e o museu, que depende de uma rede colaborativa de trabalho entre todos os especialistas envolvidos, para que uma exposição aconteça.

Devido à natureza técnica e forma de interação, as obras possuem softwares e sistemas elétrico/eletrônicos que necessitam de técnicos especializados para mantê-las em funcionamento e monitores para instruir o público durante a visita. Nesse tipo de obra sempre existe uma chance maior de imprevistos ou de ocorrer o uso inadequado dos equipamentos.

Desde o começo da década de 1990, a literatura crítica vem reexaminando o papel do museu e a prática da produção de exposições, apontando para um maior 
engajamento do público e uma mudança no paradigma do museu enquanto depósito de objetos antigos que devem ser preservados, como um relicário.

Segundo Teresa Gleadowe (2000):

O curador está agora muitas vezes inserido na produção do trabalho, atuando junto com o artista como um agenciador e está concentrado com o conjunto da experiência física e intelectual de uma exibição ou projeto. Este é um papel muito diferente daquele do historiador da arte ou curador escolar, cujo a principal tarefa era pesquisar a história de um movimento ou momento artístico em particular, para selecionar exemplares importantes do trabalho de um artista e apresentar esta pesquisa com as convenções de uma apresentação histórica. (GLEADOWE, 2000).

Mesmo a missão de manter e preservar as peças do efeito do tempo deve ser revista a partir da nova materialidade das obras, que muitas vezes existem apenas enquanto códigos de programação e utilizam os próprios recursos dos museus (como projetores, computadores e infraestrutura técnica) para serem exibidas. Os objetos artísticos estão se distanciando cada vez mais da materialidade usual de pinturas e esculturas.

Um exemplo dos desafios técnicos enfrentados pelos artistas no espaço de exposição foi descrito pelo artista Rolf Gehlhaar durante a apresentação de sua obra SOUND=SPACE, na pioneira exibição de novas mídias no museu George Pompidou em Paris, no ano de 1985.

A exposição recebeu curadoria do filósofo Jean François Lyotard, que tinha como objetivo apresentar um conjunto de obras que envolvessem arte, indústria, tecnologia da informação e cultura em uma investigação sobre os usos de vídeo, som, grupos de Usenet (um precursor do e-mail), fax, documentos escritos e interfaces visuais para navegar pelo conteúdo informacional digital.

Por se tratar de uma das primeiras experiências em exposições dessa natureza, é interessante destacar alguns dos problemas encontrados àquela época 
para entendermos os desafios enfrentados pelos museus ao redor do mundo.

A obra é montada em uma sala com um sistema de rastreamento de movimento conectado a um computador, um sampler (equipamento que grava a reproduz amostras de sons) e um sintetizador que produz sons digitalizados conforme as pessoas se deslocam pelo espaço. No entanto o artista relata uma grande dificuldade ao iniciar os trabalhos de instalação do sistema no espaço oferecido. Entre os mais sérios, ele cita a falta de uma linha de eletricidade adequada e a insuficiente quantidade de luz e ventilação do espaço. Nestas condições a obra seria completamente inviável, mas com a ajuda dos profissionais envolvidos e a improvisação de um sistema de luz e ventilação a peça pôde ser exibida conforme planejada.

Os arquitetos sempre utilizaram aspectos formais e simbólicos para expressar o uso e dar caráter às suas edificações, mas os tetos e paredes de que são construídos os edifícios incorporaram as TIC's e estão apresentando novas formas de interação e comunicação.

Uma das principais diferenças é que as fachadas dos edifícios passaram a utilizar telas e sistemas de luzes para exibir imagens e vídeos, alterando a percepção de materialidade e estabilidade da arquitetura e abrindo espaço para novas experimentações.

Como as aplicações são recentes, muitos arquitetos e empresas do setor da construção têm de desenvolver seus próprios sistemas, ou adaptar as tecnologias existentes para serem incorporadas na arquitetura. Na construção, os elementos que sofreram maior transformação foram os planos de vedações, o que incentivou o desenvolvimento de novos produtos e alternativas para o vocabulário formal dos arquitetos. 
Diversos tipos de tecnologias estão sendo aplicadas aos planos das fachadas para criar pontos de luz, ou pixels, tornando possível a reprodução de vídeos e imagens e a comunicação do edifício com a cidade.

Se na arquitetura moderna a estrutura era o elemento arquitetônico gerador e organizador dos espaços, separado e afirmado plasticamente, a arquitetura contemporânea demonstra uma experimentação maior na utilização de "peles" e camadas com planos de fechamento de materiais sofisticados, como titânio e vidros especiais, modificando o caráter visual e táctil do edifício.

Aspectos visuais como transparência, luz, reflexão e textura, são combinados de diversas formas e aplicadas ao edifício, ocultando muitas vezes os elementos estruturais que Ihes dão suporte.

A arquitetura do Museu Guggenheim de Bilbao na Espanha, por exemplo, é percebida como se fosse constituída apenas de finos planos de metal, sem que seja notada toda a malha estrutural que sustenta esta fina camada de fechamento (figura 15).

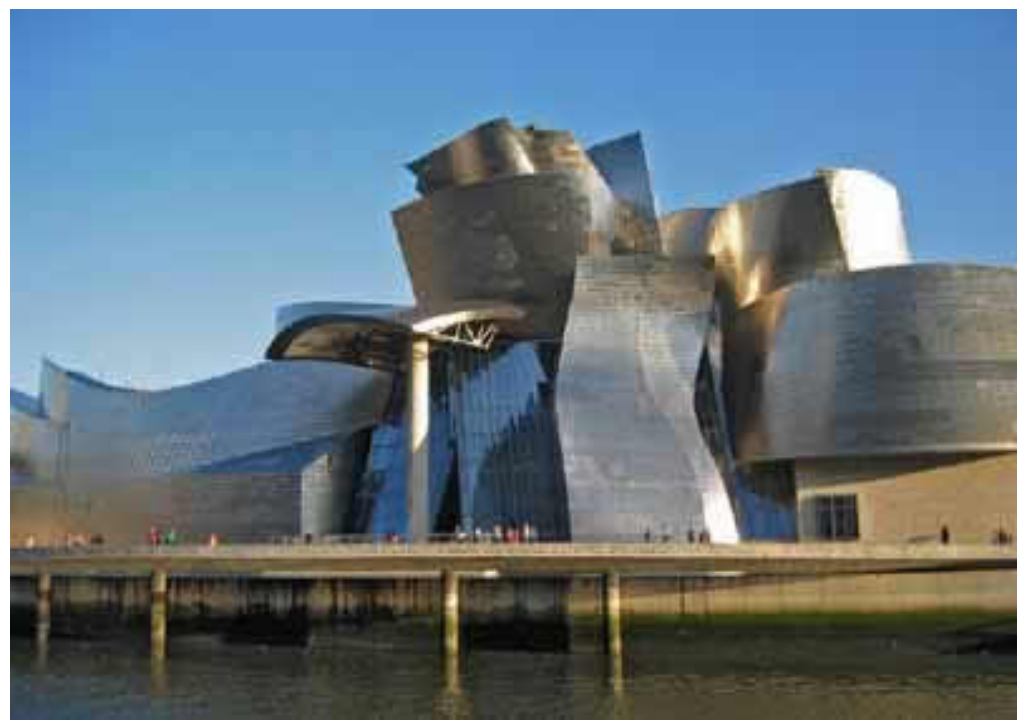

Figura 15. Museu Guggenheim, Bilbao, Espanha, 1998. 
As peles dos edifícios, devido ao próprio desenvolvimento dos materiais, passaram a ter uma maior importância, expressando o caráter tecnológico da arquitetura. Esta transformação ocorreu inicialmente nos espaços internos dos museus para posteriormente ser adotada como elemento da própria arquitetura, aparecendo integrada ao invólucro arquitetônico, às paredes e fachadas externas, e permitiu a criação de novo repertório formal e simbólico para a arquitetura contemporânea.

A tecnologia dos painéis e telas avançou muito na primeira década do séc. XXI e ficou extremamente compacta, com baixo consumo de energia e controlada por sistemas digitais automatizados. Como a imagem digital é formada por pequenos pontos de luz, chamados pixels, a utilização de LED`s proporciona uma reprodução de imagens com uma ótima qualidade e com grande eficiência energética.

De uma forma ou de outra, os pixels são os menores elementos das imagens e agora utilizados como elementos constitutivos da arquitetura. Estas grandes telas de reprodução de imagens podem assumir praticamente qualquer forma e serem utilizados como matéria-prima para a elaboração de formas complexas. Contudo, a possibilidade de criar imagens em movimento é que traz algo de novo em relação aos materiais tradicionais. A arquitetura ganha luz e movimento, de uma forma que nunca existiu.

Além disso, os sistemas cibernéticos podem ser utilizados para uma comunicação direta com seu entorno, alcançando um nível de comunicação e interação que abre novos horizontes para o papel da arquitetura e sua inserção na paisagem urbana. Com a "pixelização" das fachadas dos edifícios, a arquitetura pode se comunicar de uma maneira mais direta, como se estivesse embrulhada em 
uma tela de luz.

A chamada media art se expandiu do espaço interno dos museus para se integrarem diretamente em sua casca externa, assumindo uma escala urbana e comunicação aberta ao espaço público. O que se observa é o surgimento da media architecture, um movimento que começou com displays e telões posicionados pela cidade geralmente pregados nas paredes dos edifícios, ou presos em suportes próprios, como postes e outras estruturas.

Se nestes casos as telas eram meros apêndices das construções, a arquitetura passou a incorporá-los como parte de seu vocabulário plástico e possibilitando novas formas visuais e interação com a cidade. Com os esforços de arquitetos, media designers e especialistas em tecnologia, foram criadas estruturas híbridas de fechamento para revestir o edifício. Estas estruturas possuem fontes de luz e redes de dados integradas, para distribuição de energia, programação e controle.

Os conteúdos apresentados, muitas vezes são constituídos de textos ou reproduções de imagens, mas em outros casos são utilizados de uma forma abstrata, sem uma comunicação estritamente literal. Alguns projetos exploram sistemas automatizados para permitir a interação com a população e os transeuntes, influenciando no conteúdo apresentado, ou atualizando e gerando novas imagens e textos.

Com isso, a arquitetura de uma maneira em geral e os museus, especificamente, ganharam destaque e relevância para a paisagem da cidade e para o ambiente urbano. No entanto, existe um detalhe importante, pois não é propriamente a arquitetura que se comunica neste caso, mas os media designers e programadores que estão por trás que fazem o edifício "falar", definindo o conteúdo 
e forma de apresentação da informação.

Em todo caso, a arquitetura não deveria ser tomada apenas como uma nova forma de comunicação, mas ser avaliada em sua dimensão pública e interativa nos diferentes níveis de relações com a sociedade. É necessário se questionar a respeito dessa atmosfera interativa em torno do edifício para compreender melhor este sistema e os significados que emergem a partir de suas relações. Afinal, a criação de significados depende dessa interação e troca de informações.

O movimento criado pelo controle e exibição de imagens, proporciona o que poderia se chamar arquitetura cinética, mais apropriado do que mídia-arquitetura, já que expressa melhor a dinâmica expressa pelas suas fachadas.

Talvez a incorporação dos pixels pela arquitetura permita uma ampliação de suas funções e vocabulário formal, estabelecendo novas relações e significados para a construção de imagens e interações. Tecnicamente, o desafio está na aplicação de pixels sobre as superfícies dos edifícios e a cada tecnologia desenvolvida, novos elementos arquitetônicos são criados.

As catedrais barrocas assumiram a importância da pintura aplicada ao espaço arquitetônico e utilizaram os afrescos para produzir sensações, explorando o uso da perspectiva para alterar a percepção do espaço e induzir o espectador a um estado de espírito apropriado às atividades espirituais e o significado de um templo religioso. Existe uma mensagem evidente que busca conduzir os sentidos para produzir um estado de consciência.

Em uma arquitetura comercial, como por exemplo, os shopping centers, as mensagens veiculadas, toda a profusão de cores e luzes, obviamente busca preparar o consumidor para gastar dinheiro, tornando a experiência prazerosa e afastando pensamentos ou sentimentos que possam interferir nas compras (como 
por exemplo, perder a noção do tempo, ou esquecer que existe a miséria).

Apesar de sofrerem as pressões dos interesses do capital, os museus possuem um caráter e uma finalidade diferenciada, que Ihe empresta uma maior liberdade expressiva e de conteúdo. Sob este ponto de vista, qual seria então a mensagem ou estado de espírito que os museus poderiam transmitir?

O centro da questão não é a construção do objeto arquitetônico, mas a interação e o comportamento entre os usuários e habitantes das cidades, abrindo a possibilidade de um novo sistema. A arte pode auxiliar aqui, conduzindo novas experiências e procurando uma atitude de vanguarda, alimentando a produção de arquitetura. Não se trata tanto de desenvolvimentos técnicos, mas sim de experimentações estéticas, como no uso de imagens tridimensionais e misturas de diferentes linguagens. O uso menos comercial e mais lúdico das novas tecnologias se apresenta como uma grande fonte de inspiração para os arquitetos e todos os profissionais envolvidos na construção de novos componentes.

Novas possibilidades vão se abrindo e os caminhos para uma abordagem diferente sobre a troca de informações entre a arquitetura e a cidade ainda não atingiram um grau de maturação para que haja um fenômeno de interação que realmente traga benefícios para a vida das pessoas.

Outro museu que faz uso de pixels em suas fachadas é o Kunsthaus - BIX (2003), situado na cidade de Graz, Áustria, projeto dos arquitetos ingleses Peter Cook e Colin Fournier. O edifício se destaca do entorno de construções tradicionais da cidade, com suas formas orgânicas e profusão de luzes (figura 16). O volume principal da edificação tem forma derivada de bolhas, com aberturas tubulares em sua parte superior. Ele é revestido por placas transparentes brilhantes, que produzem um reflexo distorcido da arquitetura barroca do entorno e criam 
estranhamento, embora o museu incorpore uma antiga edificação de 1847 que foi mantida e integrada ao novo conjunto.

Abaixo desta fina casca exterior, estão dispostas lâmpadas circulares de 40 Watts cada, que podem alterar sua reprodução de cor e intensidade luminosa para formar grandes imagens integradas à arquitetura do edifício. Sem dúvida há uma forte influência na ambiência urbana que dá destaque e visibilidade ao museu. Todas as luzes da fachada estão conectadas a um sistema computacional que controla aquilo que será exibido.

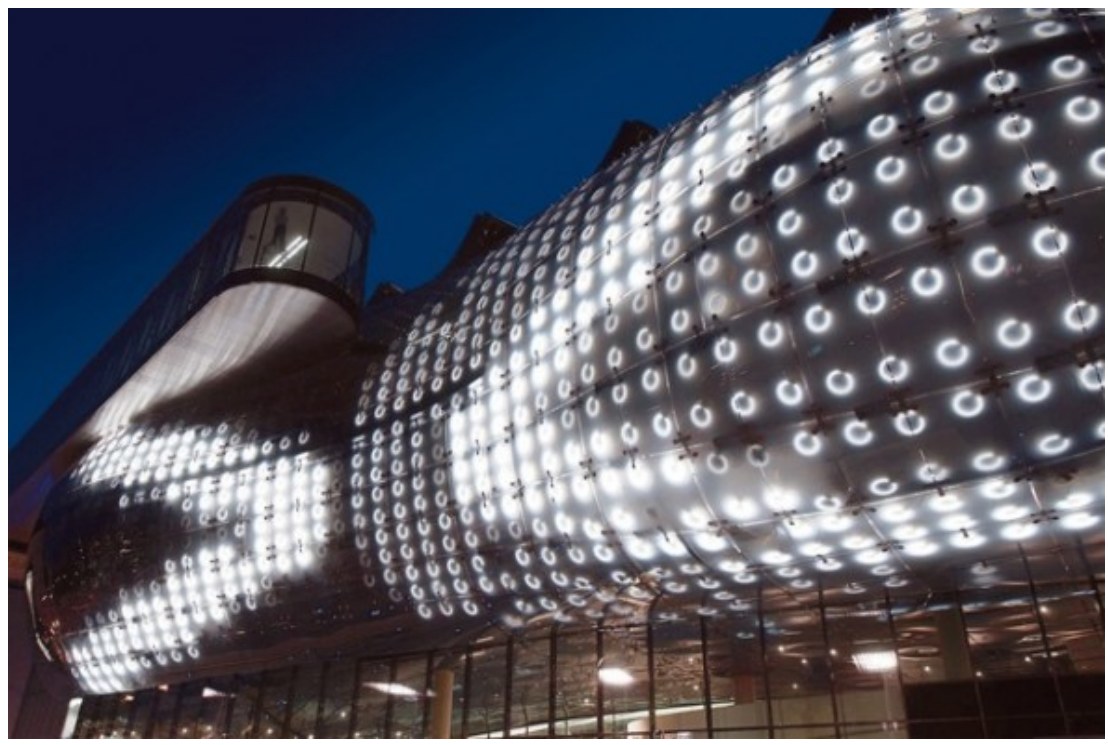

Figura 16. Kunsthaus BIX, Áustria, 2003.

A fachada do museu é utilizada muitas vezes como espaço para a exibição de obras experimentais, em alguns casos planejadas especificamente com o objetivo de explorar as possibilidades formais e de comunicação suportadas pela arquitetura. Com linha de curadoria particular, o museu não possui acervo, mostras de arte permanentes ou laboratórios de pesquisa em sua estrutura, mantendo uma 
constante busca por novas exposições, que dão dinâmica e a todo o momento alteram o espaço interno do edifício. É uma visão diferente dos tradicionais museus, que normalmente têm como uma de suas premissas o armazenamento de obras para a criação de um acervo próprio, ou a manutenção de exposições permanentes.

Com isso, uma substantiva quantidade de recursos e espaço deixam de ser necessários e a estrutura do museu se torna mais enxuta, porém é necessário uma curadoria e produção articuladas e empenhadas em manter o constante planejamento e troca de exposições.

No caso do Kunsthaus, a curadoria é focada na arte contemporânea, buscando nova apropriação do espaço expositivo, já que os espaços internos da edificação estão distantes dos paradigmas da arquitetura moderna do cubo branco.

O mais provável é que a partir da construção de novos museus, que lançam mão dos recursos formais e interativos da arte, retornem agora em um outro nível de codificação, retroalimentando a própria arte. A interatividade proposta pela arte nos espaços internos do museu e em uma menor escala, podem se ampliar para a escala do edifício, atingindo a cidade e a sociedade em maior alcance.

É importante notar um movimento que parece aproximar a arte da ciência e da tecnologia, universos que muitas vezes são apresentados como categorias diferentes, ou mesmo opostas, mas que deveriam ser entendidas com maior complementaridade.

Além disso, a arquitetura, disciplina que assume a arte como um de seus princípios, ganha relevância enquanto meio (medium) para o enriquecimento das relações com a sociedade. No museu, talvez estas características sejam ainda mais desejáveis, devido ao perfil de espaço público e gerador de identidade cultural 
para a sociedade.

É notável o papel transformador que os projetos de novos museus imprimem à dinâmica imobiliária e urbana das cidades, ampliando sua visibilidade, criando um marco histórico, valorizando o território e o sentimento de pertencimento de seus habitantes. Estes objetos arquitetônicos alteram profundamente a paisagem e se tornam referência iconográfica da cidade, veiculados em diversos tipos de mídias e associados à ideia de desenvolvimento cultural e tecnológico.

Para alcançarem este objetivo, os projetos desenvolvidos têm um alto custo e a sua execução depende de serviços especializados e materiais que, na maior parte das vezes são desenvolvidos sob demanda.

As Inovações Tecnológicas originadas da Informática e das Telecomunicações estão revolucionando o pensamento, o trabalho e a vida, e neste sentido estão servindo de base para a emersão de uma verdadeira revolução cultural. Para pensarmos estas profundas transformações temos a necessidade de esclarecer o conceito de Base Tecnológica, resultado da articulação dos conceitos de Inovação Tecnológica, Produção Material e Criação Cultural.

Com a criação e desenvolvimento de novos instrumentos e processos manipuladores da informação, foi ocorrendo gradativamente a convergência entre a informática, as telecomunicações e os diferentes tipos de mídias que levou à emersão de uma nova base tecnológica centrada e articulada pelo caráter integrador e facilitador na criação, tratamento, transmissão e recepção de Informações procedentes e destinadas às mais diferentes atividades humanas.

As cidades são construídas e produzidas a partir de redes técnicas e sociais (CASTELLS, 1996) e as tecnologias de comunicação e informação estão reconfigurando os espaços urbanos e as práticas sociais que nele se desenvolvem. 
O fluxo de informações que atravessa o planeta altera nossa percepção de tempo e espaço, repercutindo na dinâmica e conformação física das cidades e constituindo um novo território.

São inegáveis as alterações e consequências provocadas pela tecnologia informacional não apenas na base mas também na superestrutura da sociedade, portanto tais alterações tendem a se aprofundar com a transformação da tecnologia em poderosa máquina de comunicação, integrando uma rede global de computadores que dilui as fronteiras nacionais e políticas dos países.

Segundo Camargo (2006), as práticas sociais se apresentam como relações coletivas, que no plano individual representam Operações Cognitivas, dadas pela relação corpo/mente. No plano coletivo, se manifestam como operações de comunicação, dadas pelas relações intersubjetivas, e na articulação material e instrumental, dada pelo suporte tecnológico dos equipamentos técnicos e ocupando um mesmo espaço arquitetônico e urbano.

O conceito de sociedade da informação surgiu no contexto de debates acadêmicos, envolvendo cientistas sociais e economistas. Tais debates foram motivados pela percepção de que a emergência, desenvolvimento e difusão de novas tecnologias de informação e comunicação estariam na base da estruturação de um quadro de relações sociais e econômicas, configurando um novo tipo de sociedade. Nesse contexto, os autores procuram identificar os traços e as características das sociedades então designadas como pós-industriais.

Com base na reflexão de Castells (1999), pode-se visualizar uma sociedade que modificou a dinâmica das trocas de informações, migrando do meio geográfico (físico) para o meio virtual construído pelas redes. Com isso, ocorreram transformações nas relações de poder, que passaram para as mãos de quem 
detém o controle dos fluxos e conexões das redes, por exemplo.

A teoria na qual o artista computacional se apóia toma por base uma série de conhecimentos acumulados na história da humanidade, a própria raiz etimológica da palavra arte (do latim Ars) deriva de uma compreensão da importância da técnica aplicada para a construção da obra de arte. O artista parte de dados extraídos da sua realidade para criar simulações ou representações, estruturando a tecnologia a partir de uma visão estética do mundo.

Dessa forma, a nova base tecnológica gera novos produtos culturais apoiados pelos novos meios de reflexão e cognição e pelas novas formas de sociabilidade, apontando para uma verdadeira revolução cultural.

Pierre Levy (1999, p.63) explica que os dispositivos comunicacionais das TIC's podem ser divididos em 3 categorias básicas, segundo seus níveis de interatividade:

1. Um-todos: um emissor envia suas mensagens a um grande número de receptores. Ex: rádio, imprensa e televisão.

2. Um-um: relações estabelecidas entre dois indivíduos, ponto a ponto. Ex: telefone, correio, telegrama.

3. Todos-todos: dispositivo comunicacional original, possibilitado pelo ciberespaço, pois permite "que comunidades constituam de forma progressiva e de maneira cooperativa um contexto comum". Por exemplo: conferência eletrônica, world wide web, ambiente de educação à distância, etc.

O autor afirma que "as realidades virtuais compartilhadas, que podem fazer comunicar milhares ou mesmo milhões de pessoas, devem ser consideradas como dispositivos de comunicação 'todos-todos', típicos da cibercultura” (1999, p. 105). 
Vivemos em uma sociedade que se transforma a cada dia devido ao advento das novas Tecnologias da Informação e Comunicação (TIC's). A convergência dos sistemas de comunicação, das tecnologias da informação e o crescimento das redes integradas tornam-se responsáveis pela transição de uma sociedade antes majoritariamente industrial, para uma sociedade agora baseada na informação.

Alimentado pelas mudanças tecnológicas, houve também um forte desenvolvimento científico, que está levando à criação de um novo campo de estudos, fruto da convergência entre a Informática, a Eletrônica e a Comunicação.

Sob esse mesmo aspecto, Daniel Bell (apud KUMAR, 1997, p. 22) afirma que o que gerou a Sociedade da Informação foi a convergência entre o computador e as telecomunicações e que após tal convergência o computador acabou por centralizar as funções dos outros sistemas de comunicação. As tecnologias digitais, segundo Pierre Levy, "surgiram, então, como a infraestrutura do ciberespaço, novo espaço de comunicação, de sociabilidade, de organização e de trocas, mas também novo mercado de informação e de conhecimento" (1999, p. 32).

Castells (1999), visualizando o futuro da Internet como meio de comunicação, defende que a nova sociedade dependerá cada vez mais dos sistemas de informação e comunicação. O autor analisa a sociedade da informação a partir das revoluções tecnológicas que se sucederam após a formação da telemática, concluindo que as novas tecnologias da informação estão integrando o mundo em uma rede global.

Existem múltiplas redes interligadas que se tornam fonte de formação, orientação e desorientação da sociedade, "por isso, é que a informação representa o principal ingrediente de nossa organização social, e os fluxos de mensagens e imagens entre as redes constituem o encadeamento básico de nossa estrutura 
social" (CASTELLS, 1999, p. 573).

As redes constituem a nova morfologia social da contemporaneidade e a difusão da lógica das redes modifica de forma substancial a operação e os resultados dos processos produtivos, de percepção, poder e cultura.

[...] Eu afirmaria que essa lógica de redes gera uma determinação social em nível mais alto que a dos interesses sociais específicos expressos por meio das redes: o poder dos fluxos é mais importante que os fluxos do poder. A presença na rede ou a ausência dela e a dinâmica de cada rede em relação às outras são fontes cruciais de dominação e transformação de nossa sociedade: uma sociedade que, portanto, podemos apropriadamente chamar de sociedade em rede, caracterizada pela primazia da morfologia social sobre a ação social (CASTELLS, 1999, p. $565)$.

Assim como as três ondas de Toffler (1980), a sociedade, segundo Levy (1999), passou por três etapas históricas: a primeira, quando as sociedades eram fechadas, voltadas à cultura oral; a segunda, com as sociedades civilizadas, imperialistas, que utilizavam a escrita e, por último, a cibercultura, que potencializou as inter-relações globais das sociedades contemporâneas.

A cibercultura corresponde ao momento em que nossa espécie, pela globalização econômica, pelo adensamento das redes de comunicação e de transporte, tende a formar uma única comunidade mundial, ainda que essa comunidade seja desigual e conflitante (LEVY, 1999).

A cultura digital, chamada também de cibercultura, começou a ganhar representatividade no início dos anos 1980 e tem como uma de suas principais características a convergência, devido à associação dos diversos meios e linguagens produzidos em um sistema único.

O conceito de interatividade está diretamente relacionado às novas mídias digitais. O que se compreende hoje por interatividade, diz respeito a uma nova forma de interação técnica, de cunho eletrônico-digital, diferente da interação 
analógica que caracterizou as mídias tradicionais.

Em uma abordagem mais detalhada, Levy identifica diferentes níveis de interatividade oferecidos pelos dispositivos de comunicação. Abaixo há uma tabela que resume o quadro geral dos tipos de interatividade oferecidos pelas mídias, segundo o autor.

\begin{tabular}{|c|c|c|c|}
\hline \begin{tabular}{|r|}
$\begin{array}{r}\text { Relação com a } \\
\text { mensagem }\end{array}$ \\
Dispositivo \\
de comunicação
\end{tabular} & $\begin{array}{l}\text { Mensagem linear } \\
\text { não alterável em } \\
\text { tempo real }\end{array}$ & \begin{tabular}{|l|} 
Interrupção e \\
reorientação do \\
fluxo informacional \\
em tempo real
\end{tabular} & $\begin{array}{l}\text { Implicação do } \\
\text { participante na } \\
\text { mensagem }\end{array}$ \\
\hline Difusão unilateral & $\begin{array}{l}\text { - Imprensa } \\
\text { - Rádio } \\
\text { - Televisão } \\
\text { - Cinema }\end{array}$ & $\begin{array}{l}\text { - Bancos de dados } \\
\text { multimodais } \\
\text { - Hiperdocumentos } \\
\text { fixos } \\
\text { - Simulações sem } \\
\text { imersão nem } \\
\text { possibilidade de } \\
\text { modificar o modelo }\end{array}$ & $\begin{array}{l}\text { - Videogames com } \\
\text { um só participante } \\
\text { - Simulações com } \\
\text { imersão (simulador } \\
\text { de vôo) sem } \\
\text { modificação } \\
\text { possível do } \\
\text { modelo }\end{array}$ \\
\hline $\begin{array}{l}\text { Diálogo, } \\
\text { reciprocidade }\end{array}$ & $\begin{array}{l}\text { - Correspondência } \\
\text { postal entre duas } \\
\text { pessoas }\end{array}$ & $\begin{array}{l}\text { - Telefone } \\
\text { - Videofone }\end{array}$ & $\begin{array}{l}\text { - Diálogos através } \\
\text { de meios virtuais, } \\
\text { cibersexo }\end{array}$ \\
\hline $\begin{array}{l}\text { D iálogo entre } \\
\text { vários participantes }\end{array}$ & $\begin{array}{l}\text { - Rede de } \\
\text { correspondência } \\
\text { - Sistema de } \\
\text { publicações em } \\
\text { uma comunidade } \\
\text { de pesquisa }\end{array}$ & \begin{tabular}{|l} 
- Teleconferência ou \\
videoconferência \\
com vários \\
participantes \\
- Hiperdocumentos \\
abertos acessíveis \\
on-line, frutos da \\
escritura/leitura de \\
uma comunidade \\
- Simulações (com \\
possibilidade de \\
atuar sobre o \\
modelo) como de \\
suportes de \\
debates de uma \\
comunidade
\end{tabular} & \begin{tabular}{|l|} 
- RPG multiusuário \\
no ciberespaço \\
- Videogame em \\
"realidade virtual" \\
com vários \\
participantes \\
- Comunicação em \\
mundos virtuais, \\
negociação \\
contínua dos \\
participantes sobre \\
suas imagens e a \\
imagem de sua \\
situação comum
\end{tabular} \\
\hline
\end{tabular}

Os programadores buscam aperfeiçoar o diálogo entre o homem e as máquinas por meio de sistemas computacionais e interfaces intuitivas que permitam a manipulação direta da informação e tornem as rotinas de tarefas e 
processos de aprendizagem mais rápidos e eficazes.

Os estímulos sensoriais (tato, visão e audição) proporcionam um maior envolvimento da pessoa e fundem-se com as disposições interativas e hipertextuais do equipamento que lhe é exterior.

Neste aspecto, a pesquisa avançou para a análise teórica e prática das interfaces interativas, das gramáticas hipermídia, ligada às diferentes mídias e ligadas aos espaços das práticas sociais, necessárias à veiculação e acesso dos diferentes serviços pela redes de informação e telecomunicação, suportadas pelos recursos tecnológicos (hardware e software) dados pela telemática, onde o site é a sua expressão emergente.

A partir dessa conceituação de espaços cognitivos interativos, a pesquisa investiga o papel desempenhado pelas tecnologias informáticas nos processos cognitivos e comunicativos, mais precisamente aquelas suportadas pela telemática (sistemas hipermídia em ambiente de rede e espaço virtual instrumental) sublinhando questões fundamentais sobre as dimensões instrumental (espaço dominado pela ferramenta) e sensível (espaço dominado pela discussão da ideia) destas tecnologias.

Esta interface, compreendida como ambiente cognitivo comunicativo e interativo, estabelece uma articulação entre a arquitetura e as novas tecnologias disponíveis para as artes e criação cultural, o que lhe confere um caráter híbrido e dinâmico.

Segundo Camargo (2006) existem algumas tendências de interfaces telemáticas que constituem os espaços híbridos para os ambientes comunicativos e interativos: 
- Ambientes Cognitivos e Comunicativos de Criação - Ambientes VDS: do Escritório suportado pelas tecnologias de informática e comunicação aos VDS - Virtual Studio Systems.

- As Arquiteturas Virtuais - Pesquisas do Arquiteto Novak: Das Imagens de Sínteses de 3D às Arquiteturas topológicas do Espaço-Tempo de ndimensões

- As Arquiteturas Ampliadas - Movimento Hipersurface Architecture Pesquisa do Arquiteto Perrela: Do Uso dos Multimeios na Arquitetura a Arquitetura Ampliada, i.e., Espaços Concretos fundidos (interfaceados) a Espaços Virtuais.

Estas tendências são acompanhadas por transformações e adaptações no processo de design, levando a uma transferência de inovações tecnológicas para os ambientes cognitivos comunicativos interativos. Entre estas transferências podemos destacar alguns exemplos:

- Do Real Concreto ao Real Ampliado - Hiperreal - como Fusão do Concreto e do Virtual.

- Das Interfaces-Homem-Computador (I-H-C) aos Ambientes-CognitivosComunicativos (A-C-C)

- Do Hipertexto ( HTML - Hyper Text Mark up Lenguage) à Realidade Virtual (VRML- Virtual Reality Mark up Lenguage)

- Da Infografia (Ambientes de Imagens de síntese via CAD e Sistemas Especialistas) a Telemática (Ambientes partilhados nas Redes: Internet e $w w w)$ 
- Da aplicação dos Conceitos de: Interatividade Infográfica (navegação no espaço virtual), Interatividade Social (participação nos jogos sociais sociabilidade), Imersão (ou mergulho do Concreto no Espaço Virtual), Eversão (ou Retorno do Virtual no Concreto) no Design das Interfaces e/ou Ambientes.

Destas tendências pode-se observar que o Espaço Híbrido é o resultado da somatória do Espaço Concreto com o Espaço Virtual, que é igual ao Espaço Real dos Ambientes Cognitivos e Comunicativos Telemáticos.

O projeto destes espaços híbridos faz parte do escopo dos arquitetos e designers, que assumiram a formulação de conceitos avançados como as Arquiteturas Ampliadas e Arquiteturas Virtuais para explorar as questões despertadas pelos Espaços Híbridos.

Desta ação de projeto resultam, finalmente, as Arquiteturas Ampliadas e Arquiteturas Virtuais como tendências de Arquiteturas que projetam, constroem e utilizam os Espaços Híbridos.

Por um lado, o artista se interessa por uma nova forma de comunicação em ruptura com o contexto das mídias tradicionais, buscando a participação do espectador no processo de elaboração da obra de arte, o que dialoga com a própria conceituação de arte, artista e espectador. Por outro, há uma tendência em se preocupar mais com o processo de produção do que com o produto final, numa procura pela desconstrução do processo criativo. Desse modo, ela permite aos artistas tornar perceptíveis os três momentos da comunicação artística: a emissão, a transmissão e a recepção da mensagem.

$\mathrm{Na}$ arte visual, a afirmação de A. Malraux (2000, p.12) segundo a qual a obra 
de arte não é criada a partir da visão do artista, mas a partir de informações e registros de outras obras, já permite perceber o fenômeno da intervisualidade como processo de construção, de reprodução ou de transformação de modelos.

Já o conceito de "Museu Imaginário" do mesmo autor incorpora a recepção da arte pelo viés da reprodutibilidade fotográfica, uma vez que a imagem fotográfica permite criar museus individuais a partir de cópias das obras de arte (Figura 17).

Colocando a questão no campo da arte diz-nos Malraux: "para os museus do século XVIII ao século XX transportou-se o que podia ser transportado, ficando de fora tudo o que não o era: "As vitórias de Napoleão não lhe permitiram transportar a Capela Sistina para o Louvre, assim como nenhum mecenas levará para o Metropolitan Museum o Portal Régio de Chartres, os frescos de Arezzo." (1965, p. 13).

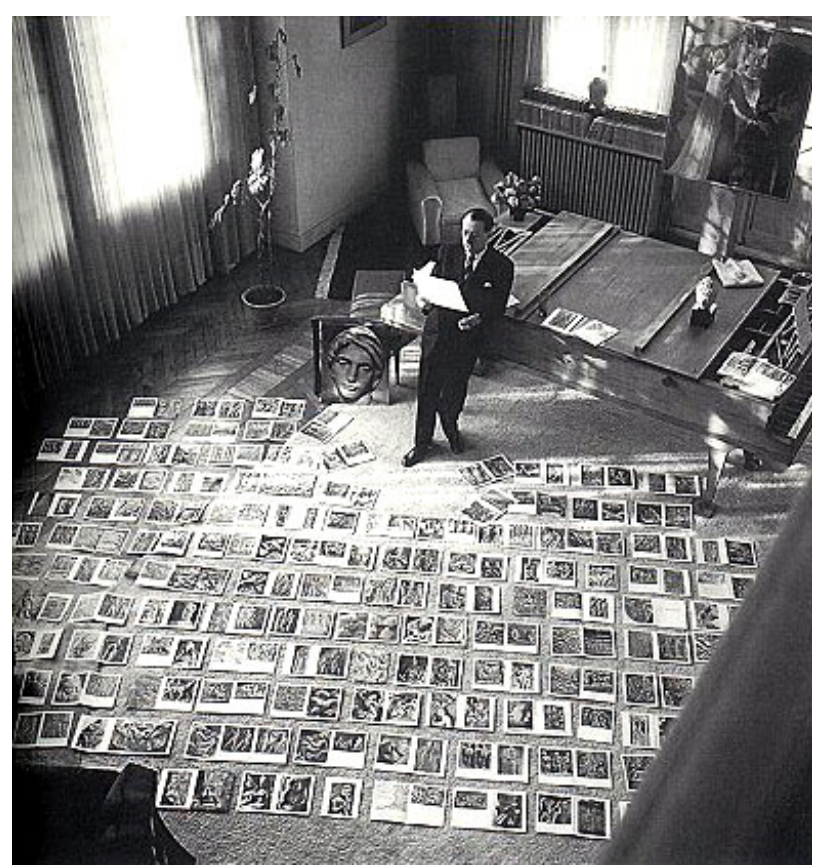

Figura 17. Malraux e seu museu imaginário, 1947.

Com os recursos das tecnologias de informação e comunicação móveis, temse hoje a possibilidade de transportar muito mais, mesmo que por via digital e 
virtual, alargando de modo significativo o conteúdo da experiência da visita ao museu.

Na década de 1960 as relações entre arte e tecnologia, com seu caráter progressivo, aceleraram-se com as novas configurações computacionais, mas é na exposição “Cybernetic Serendipity” (Londres, 1968), organizada por Max Bense e Jasia Reichardt, que se expõem, pela primeira vez, obras criadas com a ajuda do computador, despertando a polêmica questão: "pode o computador criar obras de arte?"; "obras criadas com o auxílio da informática possuem valor estético?".

Posteriormente, o artigo "Art ou non-Art?", publicado em Dossiers de L'audiovisuel em 1987, recolhe uma diversidade de pontos de vista de alguns artistas a respeito dessas questões.

Para Philippe Quéau (1996), a iconografia computadorizada anuncia-se como uma nova ferramenta de expressão artística que dispõe de um duplo campo de investigação formal e sinestésico. Segundo Edmond Couchot (1994), está emergindo uma arte visual nova, uma arte numérica e, por extensão, uma cultura fundada sobre o entrelaçamento do tecido das diferenças, não somente estéticas e éticas, mas também antropológicas e sociológicas, que não poupam pessoas nem diferenças culturais.

Os artistas tecnológicos estão mais interessados nos processos de criação artística e de exploração estética do que na produção de obras acabadas. Eles se interessam pela realização de obras inovadoras e "abertas", onde a percepção, as dimensões temporais e espaciais representam um papel decisivo.

A interatividade trazida pelas tecnologias é caracterizada pelo uso de múltiplos meios, códigos e linguagens (hipermídia), que permitem novas realidades de ordem perceptiva nas relações entre real e virtual. 
Existe hoje a possibilidade de construção de ambientes virtuais tridimensionais em exibições culturais para exploração de novas formas de comunicação e aprendizado. Estes processos estão evoluindo com o desenvolvimento de técnicas de interação homem-computador. Atualmente a possibilidade de aprender em ambientes culturais e de lazer (museus, sítios históricos, parques culturais) lança novas perspectivas sobre as possibilidades de interação do público com os recursos tecnológicos (PLAZA; TAVARES, 1998).

A economia simbólica e os modos de fabricação e circulação da arte contemporânea são, assim, afetados por esse novo contexto. O artista da comunicação e sua obra interativa só existem pela participação efetiva do público, o que torna a noção de "autor", consequentemente, mais problemática.

Os conceitos de arte, de recepção, de reprodução e mesmo o de reprodutibilidade encontram-se, atualmente, revolucionados. Lyotard (1985) já enfatizava os problemas filosóficos "pós-modernos", que eram acentuados pela transformação do mundo material e filtrados pelas tecnologias que tornam a matéria invisível, impalpável, reduzida à imaterialidade das ondas telemáticas.

O conceito de interatividade, viabilizado tecnologicamente por Ivan Sutherland em 1962, viria a se tornar uma forma cultural definitiva com a criação das artes da telepresença e das redes telemáticas nos anos 80 .

O termo "arte interativa" expande-se no começo dos anos 90 com a aparição das tecnologias de redes, ligadas ao cabo telefônico, expostas em inúmeras feiras e exposições de arte, de tecnologia eletrônica (Faust, França; Imagina, Mônaco; Siggraph, EUA, entre outras) e eventos relacionados ao videotexto, fax, slow-scan e outros meios.

Como avaliar uma arte cuja estética está baseada em uma imagem instável, 
digital, cuja persistência é absolutamente efêmera? Como avaliar um novo fazer artístico quando o próprio conceito de arte está em fase de mudança? Como não considerar a substituição do suporte físico (madeira, tela, papéis) por uma tela que emite luz?

Sendo a história da arte marcada pelo desenvolvimento dos meios e linguagens que coincidem com o desenvolvimento científico e tecnológico, não devem a produção e o pensar artísticos, como fenômeno sócio-cultural, ser constantemente reavaliados, numa tentativa de encontrar as respostas para essas mutações que vêm ocorrendo tanto nas áreas da ciência, da técnica como na da arte?

O objeto não preexiste a si mesmo. Ele não sobrevive sem o aval da sociedade. Para que qualquer objeto social possa ser delimitado, analisado e especificado em sua visível e loquaz objetividade é preciso que estabeleça relações entre instituições, processos econômicos e sociais, formas de comportamentos, sistemas de normas, técnicas, tipos de classificação e modos de caracterização (Foucault, 1975, p. 51-52).

Um artista computacional e um novo paradigma estético talvez sejam as exigências naturais da contemporaneidade deste início de século. Em termos artísticos, a tecnociência - campo de intersecção entre a ciência e a técnica, vem fornecendo à arte a quase totalidade de seus novos materiais (Couchot, 1994, p. 66).

Assim como a comunidade artística se propõe a repensar seu papel frente às novas tecnologias, é necessário que os arquitetos, curadores e especialistas, realizem o mesmo questionamento em relação aos museus.

Segundo a definição de Zbyneck Stransky (1980), a museologia é uma disciplina científica distinta e independente cujo objeto de conhecimento é uma relação específica do homem à realidade, expressa objetivamente em formas 
variadas de museus ao longo da história. De certa maneira elas se constituem em uma expressão e um reflexo parcial dos sistemas de memória. A natureza da Museologia vem de uma ciência social e se liga à esfera das disciplinas científicas de documentação da memória, contribuindo especificamente para a melhor compreensão das sociedades.

Criados para guardar a memória da produção cultural da humanidade e para promover exposições de obras de arte e coleções científicas, como deve ser um museu, localizado tanto em um espaço real como virtual, cujo acervo cultural, artístico e científico é todo baseado em processos tecnológicos de natureza eletrônica?

A criação cultural é um processo transformador da matéria que gera bens, serviços e obras de arte, segundo uma determinada visão de mundo de uma dada sociedade, em um determinado momento de sua história.

As TIC's aplicadas aos museus facilitam as tarefas do trabalho individual de inventariação, catalogação, difusão e gestão das coleções, revolucionando a forma como as instituições e as pessoas comunicam entre si. As redes telemáticas são uma ferramenta ágil e dinâmica para o desenvolvimento de diferentes projetos e ações no âmbito do patrimônio cultural, auxiliando na concepção e difusão de conteúdos culturais e pedagógicos.

A internet evidencia um enorme potencial informativo e comunicativo tanto em questões de rapidez de circulação, número de pessoas que atinge e áreas geográficas que abarca. Devido às suas características de imaterialidade, instantaneidade e união de diversas mídias, a Internet democratiza o acesso à informação e a determinados tipos de bens, facilita a comunicação entre pessoas e instituições, eliminando barreiras espaciais, geográficas e temporais. 
A internet facilita a atualização contínua da informação e propicia uma aproximação estratégica entre o utilizador e a instituição/bens culturais. Com isso pode haver uma democratização do acesso à informação e ao conhecimento e um maior acesso individual e descentralizado do público, de modo não presencial.

Há também a possibilidade de estruturação da informação utilizando o hipertexto em função do utilizador a que se dirige, organizando os conteúdos de acordo com as estratégias educativas da instituição. A internet permite também utilizar e conjugar diversos tipos de suportes, como texto, áudio e vídeo, muito úteis às características dos conteúdos que se pretende disponibilizar nos sites.

A interatividade facilita a relação entre o utilizador e a informação quando ele deixa de ser um espectador passivo e passa a tomar decisões e ser protagonista do processo de aprendizagem. Despertam-se os sentidos e desencadeiam-se diferentes mecanismos físicos, mentais e emocionais que permitem compreender, de uma forma mais efetiva, as mensagens e conceitos que se pretende transmitir.

Assim, as páginas web podem ser utilizadas em grande escala e por todo o tipo de instituições culturais, com objetivos de informar, comunicar e fornecer informações sobre o museu e sua coleção, formando uma rede de comunicação com outras instituições e com o público em geral.

Desse o modo é possível um tipo de troca de informações que vá além da mera reprodução do material impresso do museu, possibilitando interações com espaços virtuais tridimensionais e o contato com obras produzidas especialmente para a rede que explorem os conceitos de interatividade com criatividade.

A maioria dos grandes museus possui site, mas muito poucos oferecem experiência interativa ou conteúdo pensado para explorar interfaces 3D e formas mais criativas de mostrar arte pela rede. Existem exemplos interessantes, mas a 
maioria explora muito pouco a produção de material multimídia interativo e a utilização das redes sociais, o que demonstra que existe um campo enorme ainda a ser construído tanto pelos museus como pelos artistas.

\subsection{Arte e Interação nos Museus Brasileiros}

Neste capítulo serão abordados exemplos de museus que revelam características e conceitos que correspondem às reflexões e análises desenvolvidas nos capítulos anteriores.

A questão das interfaces foi focada em sua dimensão híbrida, pois é nela onde os homens (usuários) e as máquinas se encontram, é o lugar onde os processos de cognição e de intercomunicação se articulam aos processos informáticos de tratamento e transmissão da informação.

Para complementar o estudo, foram selecionados exemplos de museus no Brasil e no mundo, buscando identificar diferentes abordagens e apontar as possíveis tendências para o futuro próximo.

\subsubsection{Instituto Itaú Cultural}

O Instituto Itaú Cultural se possui forte contribuição na criação de festivais e seminários e na produção e apoio aos artistas envolvidos com a cultura digital. Ele também se destaca por ter sido um dos primeiros institutos de iniciativa privada a focar arte e tecnologia no Brasil.

A estrutura do Instituto Itaú Cultural está organizada em núcleos divididos por áreas específicas de produção e atuação. Foram criados os seguintes núcleos: 
Núcleo de Ação Educativa, Núcleo de Artes Cênicas, Núcleo de Artes Visuais, Núcleo de Audiovisual, Núcleo de Comunicação e Relacionamento, Núcleo de Música, Núcleo de Diálogos, Núcleo de Produção de Eventos, Núcleo de Tecnologia.

O museu mantém duas frentes de atuação: é um centro cultural, que oferece ao público programação gratuita e diversificada, e também um instituto, voltado à pesquisa e produção de conteúdo, ao mapeamento, fomento e estímulo à produção e difusão de manifestações artísticas em diferentes áreas de expressão.

Além destes núcleos, o instituto conta ainda com um Centro de Documentação e Referência e um laboratório de produção de ambientes virtuais, o Itaulab.

O Itaú Cultural nasceu em 1987 com o papel de criar um amplo banco de dados informatizado sobre a cultura brasileira, estimulando a pesquisa e utilização das tecnologias emergentes. O banco de dados do Instituto foi aberto ao público em 1989 e seu conteúdo foi sendo gradativamente ampliado e disponibilizado a instituições conveniadas em outros pontos do país.

Ao mesmo tempo, a realização de vídeos e mídia impressa permitiu que o Instituto contextualizasse seus conteúdos e contribuísse para a preservação da memória do país. Escolas e instituições culturais e educacionais em todo o Brasil começaram, gratuitamente, a receber esse material.

A rápida difusão das novas tecnologias e o início dos serviços de comunicação em rede deram impulso à criação de uma nova estrutura de organização do banco de dados onde estava armazenado todo o conteúdo produzido pelo Instituto durante uma década.

Novas formas de comunicação estavam surgindo e o Itaú Cultural investiu na 
criação de um site com conteúdo para acesso via Internet, criando um novo canal de comunicação com o público e levando o Instituto a começar a desenvolver suas próprias tecnologias.

Em 2000, com base no conteúdo do antigo banco de dados, revisto e ampliado, foi publicada na Internet uma grande obra on-line de referência de artes visuais, a Enciclopédia Itaú Cultural de Artes Visuais.

Em 2002, o Itaú Cultural reinaugurou sua sede com novas instalações, mais informatizadas e com maior espaço físico, ao mesmo tempo em que foi aumentando e aprofundando o trabalho com a cultura digital. A programação itinerante foi intensificada, oferecendo a um público maior os seus produtos e serviços.

Esse ano marca um direcionamento do eixo curatorial para as artes eletrônicas, um movimento que foi iniciado alguns anos antes, com a criação de um banco de dados e informatização do acervo, interesse pelas videoinstalações além de novos serviços de comunicação e disponibilização de conteúdo via internet.

A instituição faz uso das TIC's para disponibilizar essas informações e assim democratizar o acesso aos bens culturais e informações sobre arte e cultura.

A programação traz também cursos, oficinas, workshops e ações educativas. Entre suas atividades destacam-se ainda os shows, as exposições de arte e os programas de apoio, intitulados Rumos Itaú Cultural.

O programa Rumos apoia a produção artística do país nas áreas de pesquisa, mídias interativas, cinema e vídeo, dança, artes visuais, literatura e música. Cada área de expressão tem um formato específico de apoio. Desde sua criação em 1997, o programa - de âmbito nacional - recebeu mais de 7 mil projetos. Ao longo desses anos, o programa Rumos gerou dezenas de exposições e shows, vídeos, 
livros, CDs e CD-ROMs, além de bases de dados sobre diversas expressões artísticas brasileiras.

O Itaulab, laboratório de mídias interativas, inspirado nos media centers europeus, é um centro de pesquisa para produções acadêmicas e artísticas. No início, era uma das áreas de atuação do Instituto Itaú Cultural e chamava-se Núcleo de Novas Mídias. Em seguida, passou por uma pequena mudança a passou a se chamar Núcleo de Mídias Interativas, mantendo o foco na investigação de novas tecnologias aplicadas à arte.

Inaugurado em 2002, na primeira Bienal Brasileira de Arte e Tecnologia (Emoção Art.ficial), rapidamente estabeleceu contato com inúmeros media centers de todo o mundo. Os objetivos do Itaulab são a troca de experiências com instituições acadêmicas e a pesquisa utilizando os recursos das novas mídias aplicadas às áreas artísticas e educacionais.

O laboratório atua em projetos que envolvem a modelagem de universos em 3D e a construção de ambientes virtuais imersivos, utilizando tecnologias de games de última geração. O resultado das pesquisas é verificado na forma de reconstituições históricas e passeios virtuais. Em 2003 foi montada a exposição Paulista 1919, uma reconstrução da Avenida Paulista feita com base em fotos do começo do século passado que permite ao espectador realizar um passeio virtual pela história e caminhar pela avenida no início do século XX.

O projeto arquitetônico do Itaú Cultural foi desenvolvido por uma equipe dirigida pelo arquiteto Ernest Robert de Carvalho Mange e organizado em nove pavimentos-tipo, um pavimento térreo, mezanino, um anexo ao primeiro pavimento e cinco subsolos.

Todas as áreas do edifício seguem uma modulação espacial que permite a 
flexibilização de sua ocupação; a estrutura metálica foi utilizada pelos arquitetos como forma de partido arquitetônico, expressando uma linguagem que traz referências tecnológicas, em que a expressão plástica do aço ganha destaque na concepção estrutural do edifício.

Pode-se ler aqui uma continuidade da arquitetura do Movimento Moderno, onde a estrutura é utilizada como elemento de expressão da tecnologia utilizada. Sua concepção leva em consideração o uso correto dos materiais, assumindo o compromisso em revelar a lógica construtiva do edifício.

O edifício destaca-se por sua estrutura metálica aparente, que alia a linguagem formal e estrutural, liberando o espaço interno de pilares e criando uma expressão plástica que rompe com a arquitetura ortogonal tradicional (Figura 18).

O desenho estrutural marca uma diferenciação na base do edifício através de pórticos de travamento que criam o embasamento para o volume principal, com módulos de travamento sucessivos que vão até o topo, arrematado pela estrutura da antena.

Essa disposição plástica expressa a separação funcional entre estrutura e fechamento, que expõe o funcionamento estrutural do edifício. Esta forma de expressão é recorrente e foi levada ao limite pela arquitetura hi-tech nos anos setenta.

Norman Foster, Richard Rogers e Renzo Piano, utilizaram em muitos de seus projetos o desenho estrutural como forma de partido arquitetônico e expressão plástica de um apuro da técnica e da utilização de materiais industrializados e padronizados. 


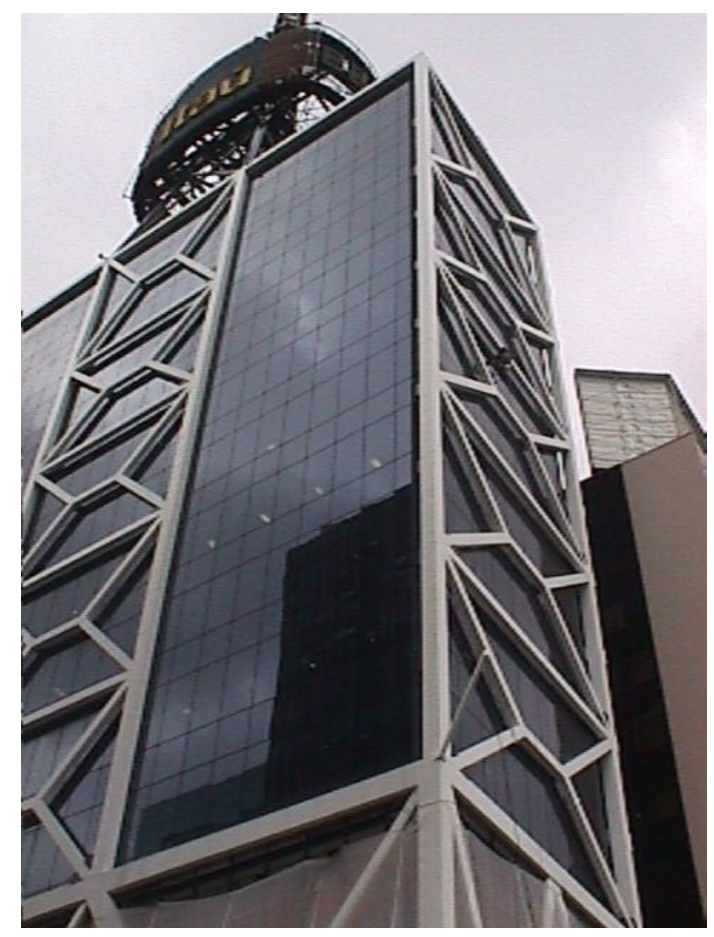

Figura 18. Fachada do edifício do Itaú Cultural, onde pode-se observar a estrutura metálica externa pintada de branco.

Um exemplo desse tipo de arquitetura é o Centre Pompidou (conhecido como Beaubourg) em Paris (1979), de autoria de Richard Rogers e Renzo Piano, que se tornou um ícone da arquitetura, com sua expressiva estrutura metálica externa, o tubo de circulação de escadas rolantes destacado na fachada e o aspecto industrial dos tubos de infraestrutura e dutos aparentes (figura 19).

Em 1995, o Instituto Itaú Cultural sofreu uma reforma, projetada por Roberto Loeb, em que o edifício recebeu modificações de acabamentos, circulações e entradas. A missão foi transformar o edifício, que havia sido criado para a realização de pesquisas internas, em um espaço mais aberto ao público, oferecendo cursos, exposições, cinema, centro de documentação, eventos e palestras. 


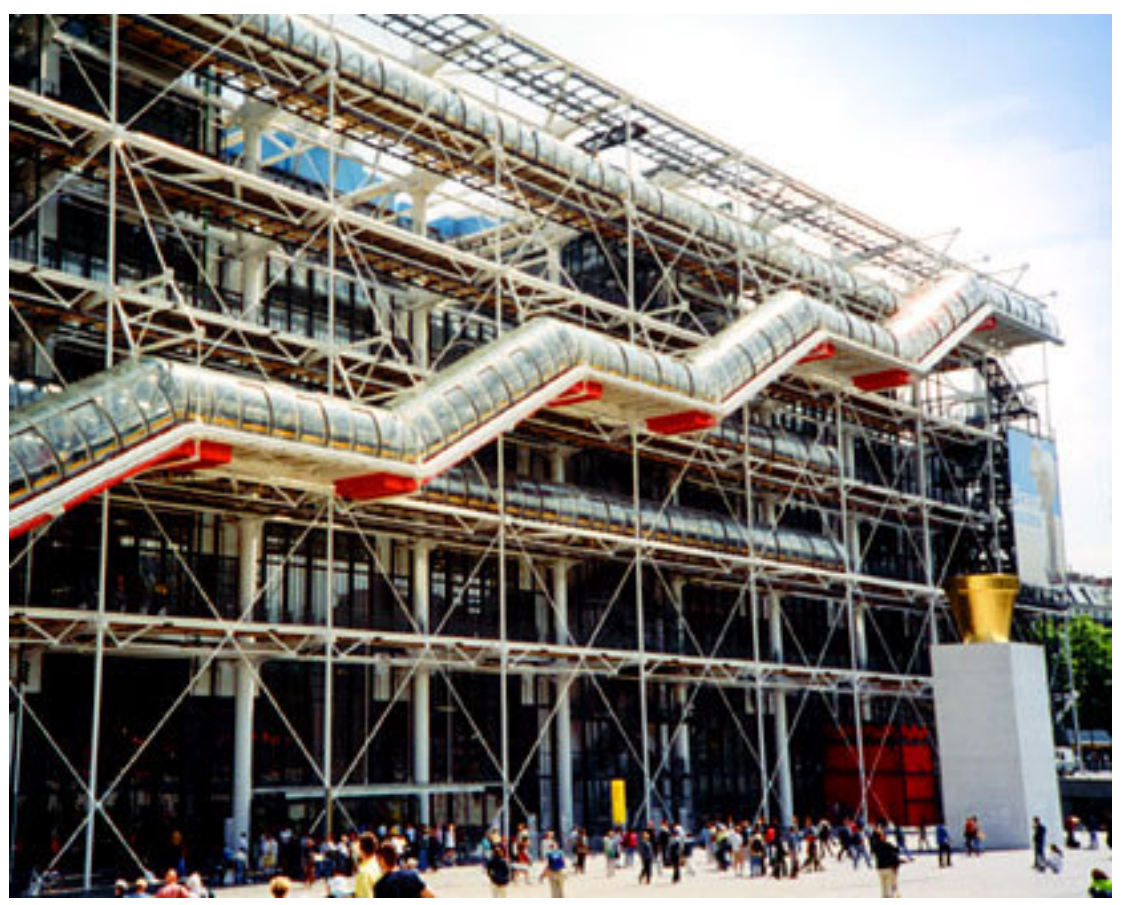

Figura 19. Museu Georges Pompidou, Paris, 1977.

Com a reforma, a instituição ganhou mais um andar para exposições no segundo subsolo, destinado às mostras experimentais. No primeiro mezanino e no primeiro subsolo, as áreas expositivas foram ampliadas. Em todos os setores dedicados às exposições o chão foi coberto por uma resina especial utilizada em indústrias, resistente a choques e a materiais químicos. Além disso, foi criado um novo andar para exposições, no segundo subsolo, dedicado às mostras experimentais.

No piso térreo, o prédio dispõe da Sala Itaú Cultural, auditório para 300 pessoas, que abriga mostras de filmes digitais, espetáculos de música, dança e teatro, encontros literários, entre outras atividades.

No segundo mezanino, uma sala multiuso e uma arena abrigam oficinas educativas, pequenos espetáculos e exibições de vídeo. No mesmo andar também passa a se localizar o Centro de Documentação e Referência, para consultas, com 
midiateca composta de biblioteca, hemeroteca e outros instrumentos de pesquisa. O primeiro andar foi destinado à realização de seminários, congressos e ciclos de palestras, com auditório de 90 lugares e toda a infraestrutura para eventos desse porte.

O museu possui um banco de dados importante, disponibilizado pela internet na Enciclopédia Itaú Cultural de Artes Visuais (figura 20), que auxilia a pesquisa e educação sobre os principais artistas nacionais e estrangeiros que atuaram e atuam no Brasil, apresentando obras, críticos e colecionadores, movimentos e grupos artísticos. Disponibiliza também um glossário de termos e conceitos empregados no âmbito das artes visuais. A enciclopédia possui um acervo que é constantemente atualizado e ampliado, com conteúdo multimídia e percursos interativos que buscam esclarecer conceitos e apresentar informações sobre o campo da arte no Brasil.

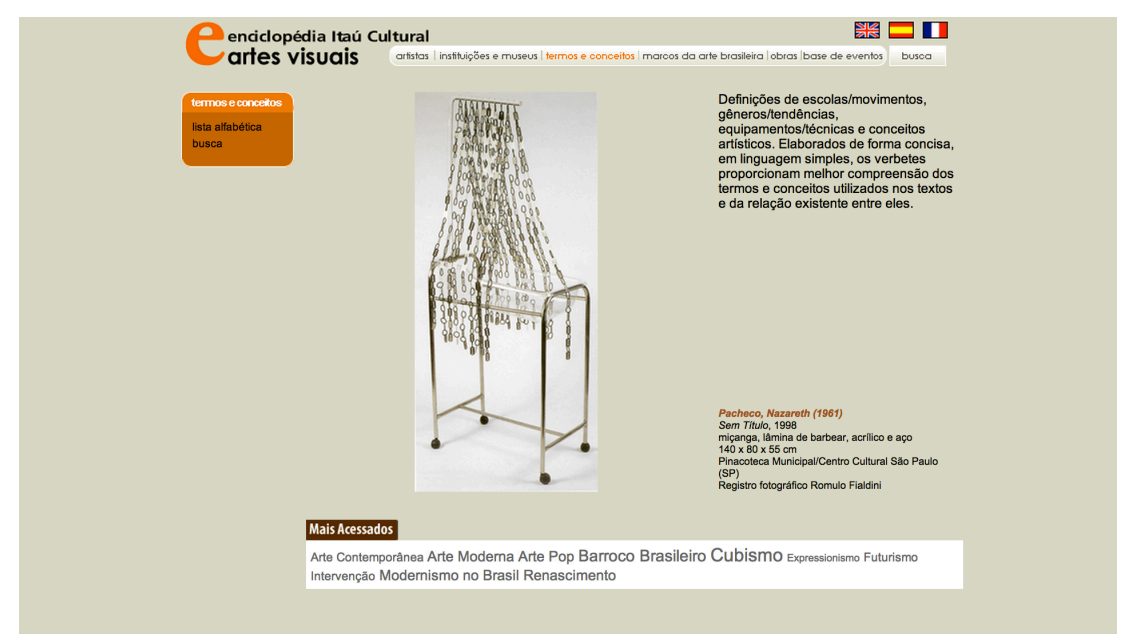

Figura 20. Site Enciclopédia Itaú Cultural de Artes Visuais. 


\subsubsection{Museu da Língua Portuguesa}

O Museu da Língua Portuguesa é um museu interativo localizado no histórico edifício da Estação da Luz, em São Paulo (figura 21), considerada a porta de entrada da capital paulista, desde o fim do século XIX. O museu está instalado no edifício localizado acima da plataforma de trens, em região central da cidade.

O projeto foi iniciado em 2002, quando se começou a restaurar o prédio da Estação da Luz, sendo concluído em 2006. Teve como aliada no projeto a Lei de Incentivo à Cultura (Lei Municipal n. 10923/1990), que dispõe sobre incentivo fiscal para a realização de projetos culturais, inclusive para museus e centros culturais.

A cidade de São Paulo tem valor simbólico para o local do museu, já que é a maior cidade de falantes da língua portuguesa no mundo, com quase vinte milhões de habitantes.

O projeto e implementação do museu são resultado de uma parceira públicoprivada e a ideia original foi desenvolvida pela Ralph Appelbaum Associates, uma empresa norte-americana especializada na criação de museus e exposições. 0 projeto arquitetônico do museu foi realizado pelos arquitetos Paulo e Pedro Mendes da Rocha, que também são autores da revitalização do edifício da Pinacoteca, situado em frente à Estação da Luz (figura 21).

Seu acervo é predominantemente virtual, combinando arte, tecnologia e interatividade, abriga exposições nas quais são utilizados, vídeos, sons e imagens para se comunicar com o público em um edifício de grande valor histórico e simbólico para a cidade. 


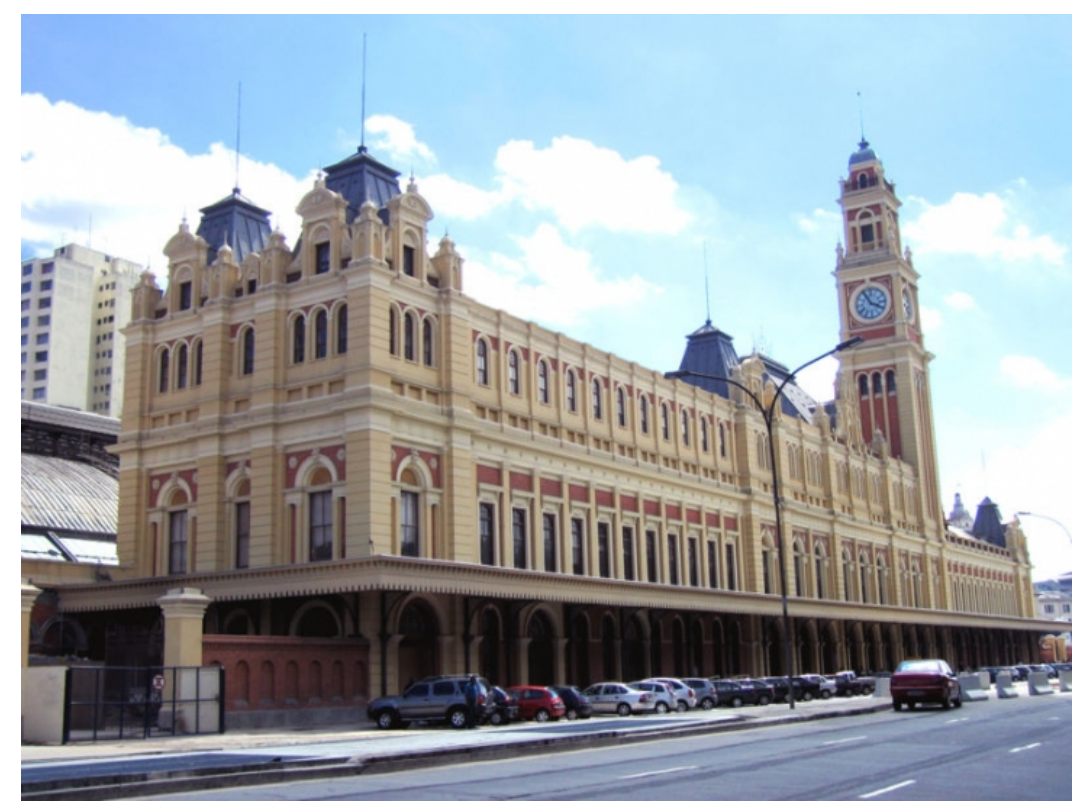

Figura 21. Edifício da Estação da Luz.

Na entrada do primeiro pavimento, há uma galeria (figura 22), com 106 metros de comprimento e 38 projetores que exibem simultaneamente três filmes sobre as relações da língua portuguesa com variados aspectos da cultura brasileira.

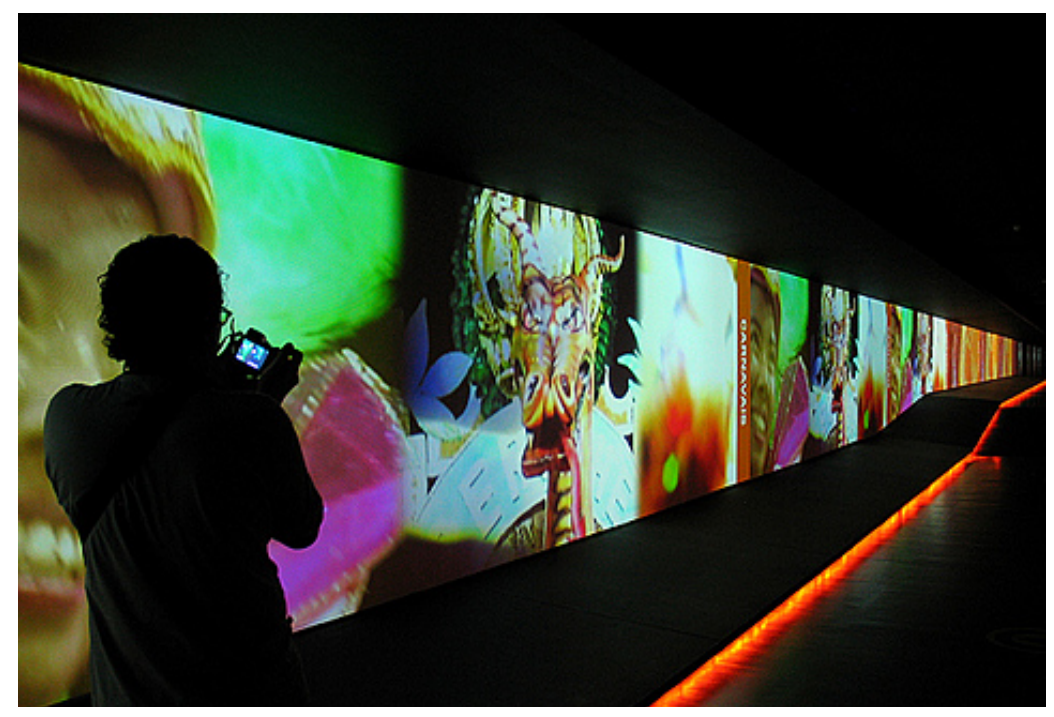

Figura 22. Vista da galeria de entrada.

Ao invés de um acervo tradicional de obras de arte o visitante vivencia uma 
série de experiências sensoriais e interativas com a Língua, por meio de recursos audiovisuais e tecnológicos.

No último piso há uma sala de projeções onde foram posicionados quatro projetores de cinema apontados para cada uma das, formando uma projeção em 180 graus que envolve o público. As pessoas, sentadas no chão, assistem às projeções olhando para o alto, e o teto se transforma em uma espécie de céu dinâmico que brinca com o significado das palavras (figura 23).

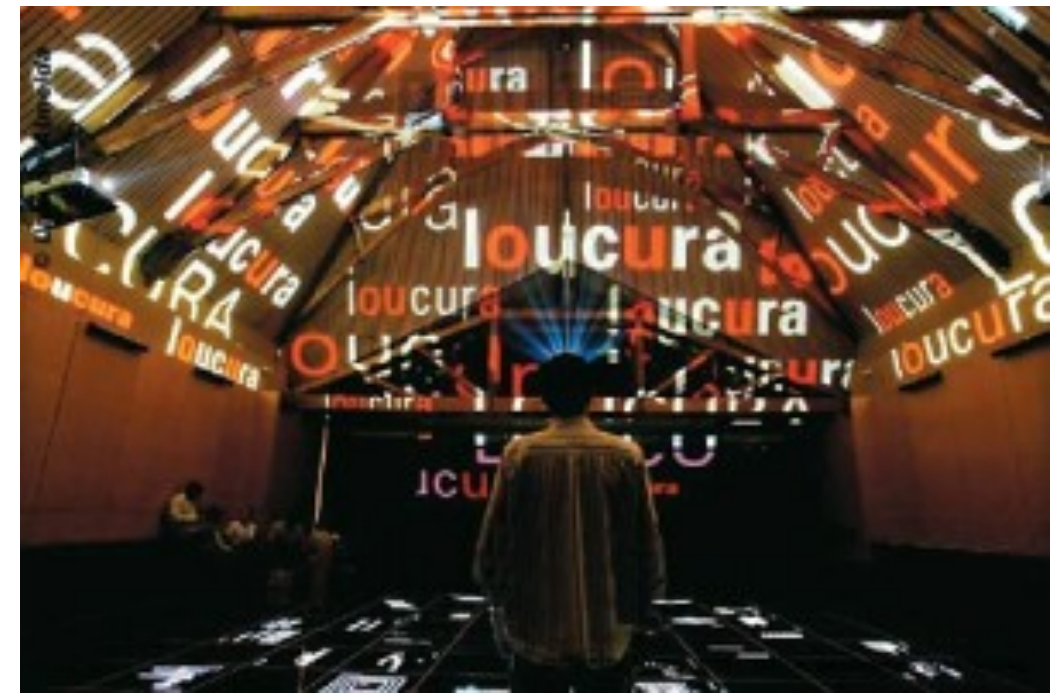

Figura 23. Praça da Língua, Museu da Língua Portuguesa, 2004.

Nesta instalação a produção e idealização aproveitaram de forma inteligente o espaço, tirando partido do forro da cobertura do edifício existente, que revela a estrutura do telhado. Pode-se perceber o trabalho cuidadoso e a presença de uma equipe multidisciplinar na criação do projeto.

A experiência propiciada consegue envolver os sentidos e a qualidade de som e imagem colabora para isso. As pessoas ficam sentadas em arquibancadas ao redor da sala e tudo acontece no teto, criando uma abóboda de projeção. 
No espaço chamado Palavras Cruzadas, foram concebidos oito totens interativos dedicados às influências das línguas e dos povos que contribuíram para formar o português do Brasil. São terminais com telas sensíveis ao toque e alto falantes direcionais, que permitem ao visitante acessar um conteúdo multimídia sobre as origens de algumas palavras e a evolução da Língua Portuguesa.

Nesse mesmo espaço há um painel que descreve a Linha do Tempo da História da Língua Portuguesa, formado por três linhas paralelas: a linha da língua portuguesa, a linha das línguas africanas e a linha das línguas ameríndias. A partir do século XVI, as três linhas se fundem em uma única: a Linha do Português do Brasil. Durante o percurso, o visitante acessa conteúdos interativos em alguns terminais multimídia e assiste a vídeos que auxiliam a percorrer a história do idioma falado no país.

A principal obra interativa está no beco das palavras. Em uma sala escura, uma mesa eletrônica com imagens projetadas utiliza a tecnologia de sensores de infravermelho para captar os movimentos dos braços das pessoas sobre a mesa e proporcionar uma interação com as imagens projetadas. Fragmentos de palavras flutuam dispersamente sobre a mesa e as pessoas têm que cercá-los com as mãos para formar as palavras. Ela cria um jogo que apresenta informações de som e vídeo, revelando a etimologia de cada um dos termos e referências da nossa cultura ligadas à cada palavra.

Com relação à intervenção em edifício histórico tombado, ocorreram diversos pontos de atrito e divergências sobre os limites do projeto com os órgão responsáveis pelo patrimônio.

"Grande parte dos técnicos é visceralmente contrária à intervenção em bens tombados, e o projeto interferia muito na edificação original. Mas o importante é que 
não se prejudiquem os espaços essenciais, que efetivamente caracterizam o edifício, como a gare e a torre do relógio, por exemplo. Fomos favoráveis à mudança porque o tombamento não pode significar a mumificação", afirmou Carlos Lemos, arquiteto e historiador. Um dos arquitetos responsáveis pelo projeto, Pedro Mendes da Rocha disse: "Não se pode tocar o prédio só um pouquinho, sob pena de não se fazer uma boa intervenção. Nossa preocupação foi sempre a de constituir, além do passado, o patrimônio do amanhã" (PROJETODESIGN, 2006, n. 315, p. 43).

Para Paulo Mendes da Rocha (2006), se a questão não era rigidamente quantitativa, um dos méritos do projeto foi quebrar a estanqueidade de espaços labirínticos e isolados, como no caso da Grande Galeria, extenso espaço localizado junto à fachada posterior do edifício, que percorre todo o comprimento da edificação. "Seria interessante exibir mais uma vez o tamanho todo da gare. A galeria, assim, não é grande nem pequena, tem o tamanho exato da estação" (ibid., p.45).

\subsubsection{Museu do Futebol}

Em termos de identidade cultural, talvez não haja um tema mais apropriado do que o futebol para representar o espírito brasileiro e a escolha do local onde foi implantado o museu corresponde completamente à intenção de criar uma atmosfera emotiva de "brasilidade".

O museu foi construído no Estádio do Pacaembu (Figura 24), que faz parte da história e da memória da cidade de São Paulo. De propriedade da prefeitura da cidade, situa-se em área central e se caracteriza por ser um estádio de menores proporções, que deixa o torcedor mais próximo ao campo. 


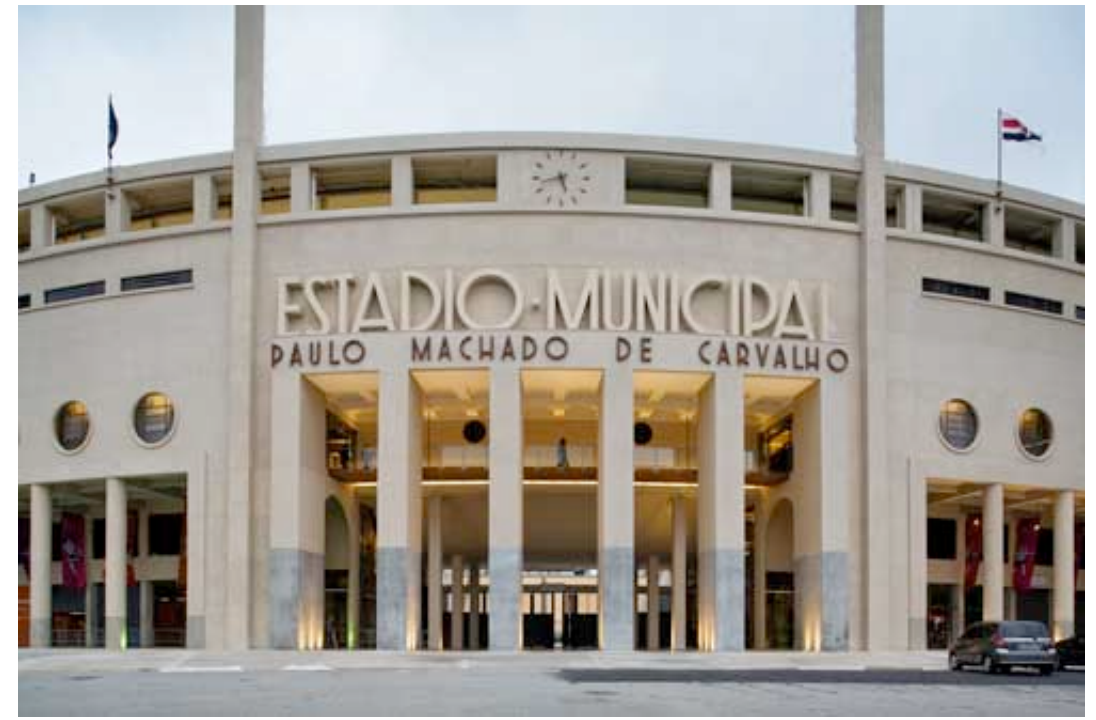

Figura 24. Acesso principal do estádio do Pacaembu, o eixo longitudinal divide o museu em duas alas interligadas pela passarela de madeira que pode se vista acima da entrada.

Existe uma nova abordagem sobre a questão da identidade nacional por meio de museus temáticos como o Museu do Futebol e o Museu da Língua Portuguesa, que utilizam a arte e as TIC's para criar interação e entretenimento em museus temáticos.

Nesse sentido, a presença das tecnologias digitais e de dispositivos multimídia demonstra, além da intenção de produzir sensações e conduzir a atenção do público, a vontade de criar um espaço que transmita a ideia de um país avançado. Por meio destes recursos, o Museu do Futebol busca transmitir uma imagem de modernidade, relacionada à tecnologia.

Ao invés de um edifício completamente novo, o museu foi instalado no Estádio do Pacaembu, utilizando de maneira criativa e eficaz o espaço residual que existia sob as arquibancadas do estádio.

Outra qualidade do projeto foi estabelecer um diálogo com o grande espaço exterior que há na frente do edifício, configurando uma praça pública (Praça 
Charles Miller) que agrega usos múltiplos (espaço para shows e festas, feiras aos domingos, ensaios das torcidas, estacionamento em dias de jogos, entre outros).

O arquiteto Mauro Muñoz elaborou um projeto complementar - ainda não viabilizado - que transforma a área numa grande esplanada, com estacionamentos subterrâneos sob as duas ruas laterais, que, atualmente, com residências de alto padrão, ficam inundadas de automóveis em dias de jogo. Para ajudar a dar vida ao local, todos os ambientes complementares - lojas, cafés, restaurante, auditório e bilheteria foram voltados para a praça e ocupam a galeria da entrada principal do piso térreo.

O estádio tem muita identidade com a cidade, por se tratar de edifício histórico e palco de grandes eventos, que reúnem milhares de pessoas. Estar junto dessa grande arena, dá ao espectador uma sensação de imersão, similar à experiência de estar em meio à torcida em um jogo de futebol.

No museu estão expostas imagens e vídeos desde 1896, quando o inglês Charles Miller chegou ao Brasil. Além dos grandes fatos, feitos memoráveis e datas solenes, o museu também explora a história dos hábitos, costumes, vestimentas e gestos do povo brasileiro, década a década.

As áreas expositivas foram separadas por temas e utilizam sistemas de áudio, projeções, terminais multimídia interativos e um projeto cenográfico que estimula os sentidos e a interação das pessoas.

O museu não se limita a tratar apenas de futebol, mas explora a própria história do Brasil e da cultura brasileira, o que reforça a ideia de identidade nacional. Fatos históricos, momentos políticos e econômicos, acontecimentos que marcaram época, figuras ilustres e manifestações culturais e artísticas são apresentados como forma de criar uma narrativa que vai além do universo do 
esporte.

O Museu do Futebol não possui acervo e, para atrair os visitantes, a museografia (criada pelos curadores Daniela Thomas e Felipe Tassara) utiliza principalmente obras interativas com conteúdo multimídia, tal como o Museu da Língua Portuguesa (também idealizado com a participação da Fundação Roberto Marinho).

O museu foi organizado em duas alas e se desenvolve verticalmente, distribuído em três pisos. O percurso segue uma organização linear da história e os espaços expositivos contam com instalações interativas e recursos multimídia.

Como no Museu da Língua Portuguesa, o uso de totens como elementos expositivos, dá ao espaço permeabilidade e liberdade de deslocamento aos visitantes. O desenho dos totens permite explorar todos os seus lados e fazer com que mais pessoas possam interagir com o mesmo objeto, que pode ter diversas interfaces incorporadas (figura 25).

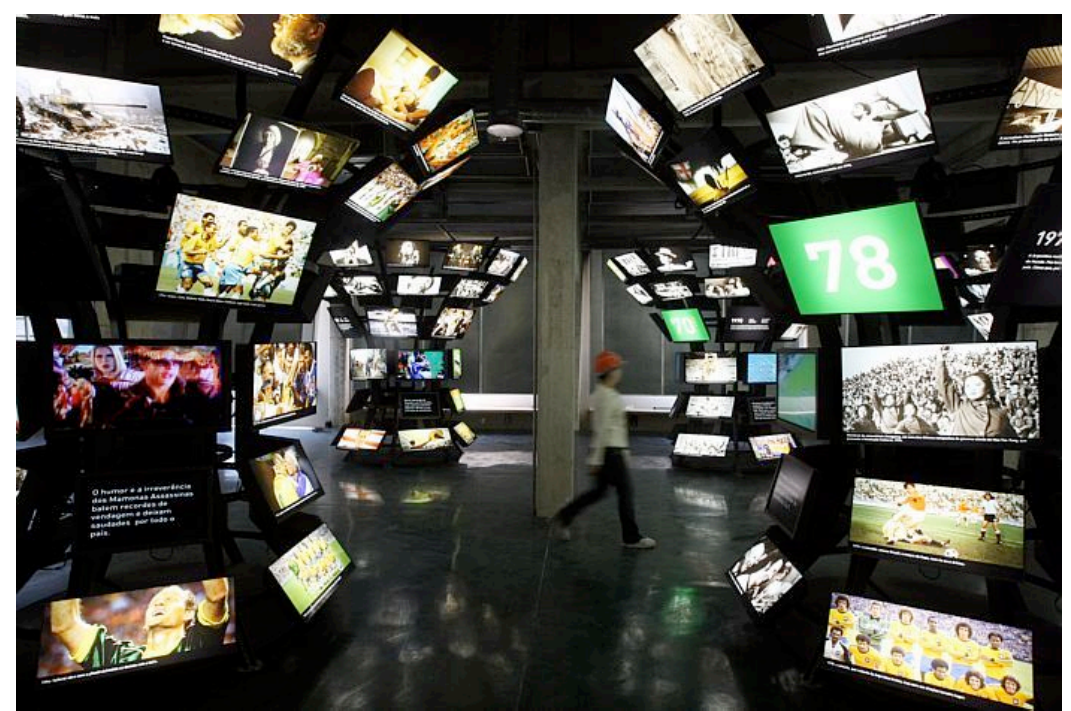

Figura 25.Totens com telas iluminadas apresentam imagens de acontecimentos históricos e momentos memoráveis do futebol.

No final do primeiro piso, chega-se a um dos espaços mais interessantes do 
museu: a Sala da Exaltação (figura 26). Neste espaço foi criada uma passarela metálica sob a arquibancada do estádio, que permite ver a relação estabelecida entre o edifício e a topografia existente, onde os pilares de concreto se apóiam sobre as rochas originais do terreno.

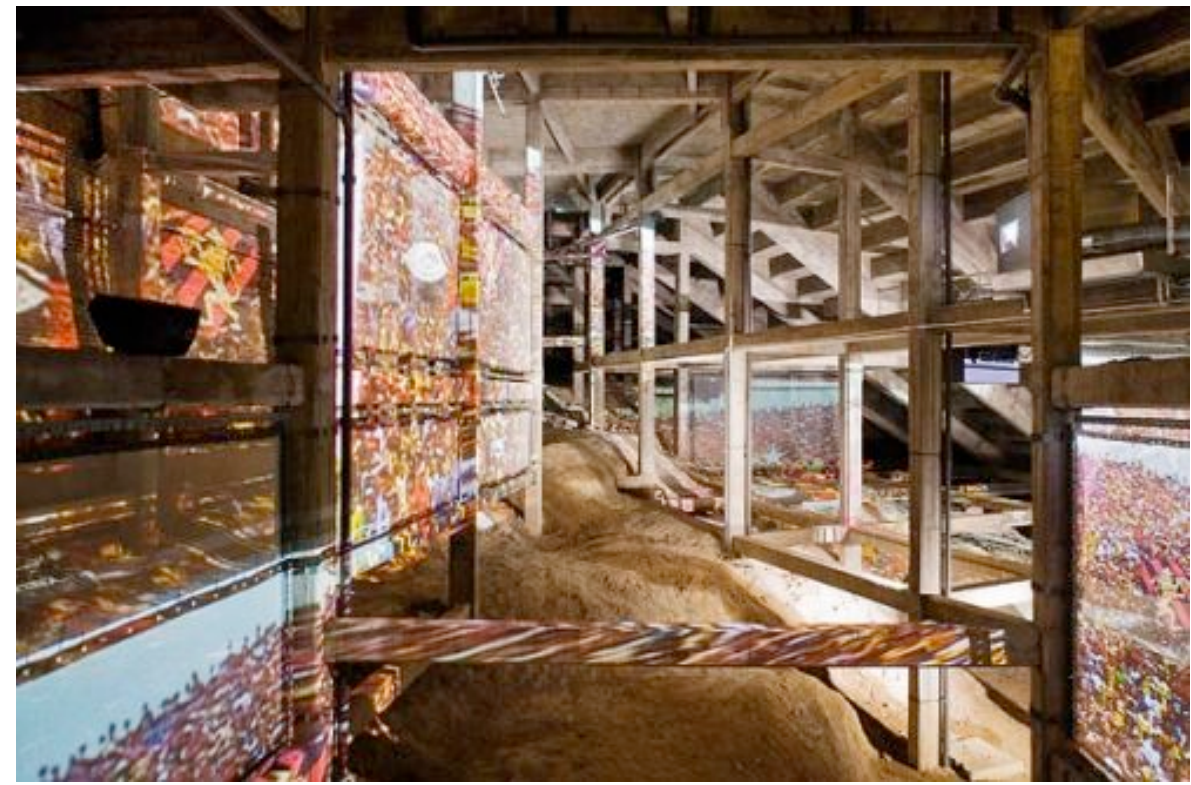

Figura 26. O Espaço da Exaltação provoca sensações de tensão e encantamento, se apropriando de forma criativa do espaço residual entre a arquibancada e o talude natural do terreno. Os diversos planos de projeção que se acendem e apagam e o uso de sistema de som surround, provocam vertigem nos espectadores.

Foram dispostos diversos projetores que inundam o espaço com imagens movimentadas de torcidas organizadas. Foram dispostas telas de projeção explorando a profundidade e dramaticidade da topografia existente, com imagens captadas do meio da torcida que buscam simular as sensações do jogo.

O uso de sistema de som 3D ajuda na imersão, explorando a espacialidade sonora que transmite ao mesmo tempo tensão e encantamento e transporta o espectador para dentro do jogo.

Além disso, é possível fazer ali uma leitura da topografia original do terreno onde foi implantado o edifício e compreender como a estrutura foi encaixada ao desnível acentuado do vale existente, revelando as fundações do projeto realizado 
na década de 1940 pelo escritório de Ramos de Azevedo.

Em outro espaço do museu o conceito de interação foi utilizado sem o uso de recursos tecnológicos avançados. Ali as paredes foram cobertas por quadros, como em um museu do séc. XVIII, mas alguns deles são giratórios e o visitante pode girálos para descobrir mais imagens e informações sobre aquele quadro (figura 27). Apesar de não utilizar alta tecnologia, a interação funciona e atrai a atenção dos visitantes, demonstrando que o conceito de interatividade é mais importante do que a presença da tecnologia em si.

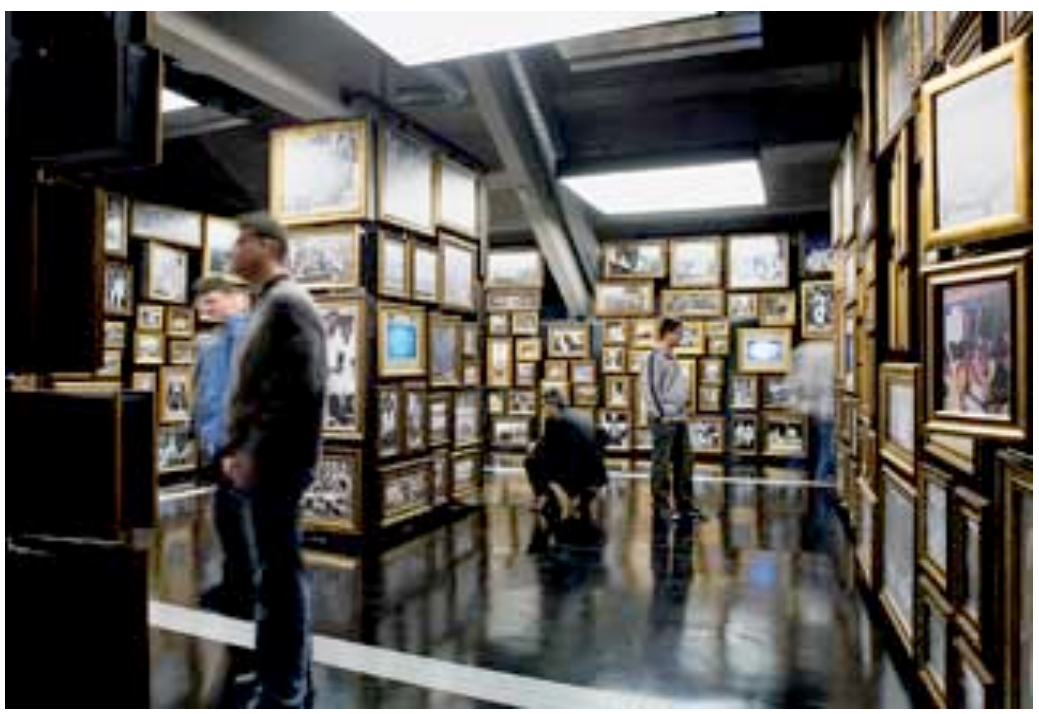

Figura 27. Neste espaço, imagens sobre a cultura brasileira, com seus costumes, música, comida, festividades e figuras ilustres, foram enquadradas em molduras antigas e permitem que 0 espectador gire os quadros para descobrir outras imagens e informações.

No segundo piso, foram mantidas as aberturas circulares do edifício, com um fechamento em telas metálicas, que permite a relação visual entre o interior e o exterior do edifício. A mesma postura foi adotada na passarela que liga as duas alas do museu, localizada acima do eixo de entrada do estádio. Este mesmo eixo divide o Museu e o Estádio simetricamente, o que evidencia a postura de integrar 
os espaços e estabelecer um diálogo entre a arquitetura e a cidade.

Tanto o Museu do Futebol como o Museu da Língua Portuguesa, possuem o mérito de utilizar o espaço existente com equilíbrio, sem interferir de forma agressiva e estabelecendo um diálogo que reforça as qualidades do edifício e Ihes dá um novo sentido. Em ambos comparece o tema do patrimônio histórico, com aspectos relacionados à memória e à história da cidade, e sua representação simbólica.

Além disso, por serem patrimônio histórico tombado, possuem diversas restrições quanto às intervenções e são um dos dados que ajudam a estabelecer o partido do projeto.

O edifício da estação da luz tem um uso completamente diferente do estádio do Pacaembu, mas os projetos souberam aproveitar os espaços existentes para acomodar as instalações e oferecer funcionalidade para os usos de um museu.

O Museu do Futebol e o Museu da Língua Portuguesa não são os únicos exemplos no Brasil que utilizam a tecnologia como suporte para suas exposições, mas apresentam muitas das características que estão presentes na maioria deles e servem para reflexão sobre questões culturais referentes à realidade brasileira.

\subsubsection{FILE}

O Festival Internacional de Linguagem Eletrônica é uma organização cultural sem fins lucrativos, organizada pelos artistas Ricardo Barreto e Paula Perissinoto, com o objetivo de disseminar e desenvolver arte, tecnologia e pesquisa científica por meio de exibições, debates, leituras e cursos.

O festival acontece anualmente na cidade de São Paulo e atualmente se 
expandiu para Porto Alegre e Rio de Janeiro, reunindo artistas nacionais e internacionais que expõem seus trabalhos em galerias e espaços públicos das cidades.

Entre as categorias de arte interativa apresentadas no festival estão: arte eletrônica, web art, net art, vida artificial, ficção hipertextual, animação computacional, arte interativa, realidade virtual, filmes interativos, instalações de arte eletrônica e salas imersivas.

O File tem realizado simpósios durante os festivais, que já contaram com a presença de importantes artistas, intelectuais, teóricos, pesquisadores e cientistas como Ted Nelson, Lev Manovich, Bill Vorn e George Landow, procurando estabelecer diálogo e cooperação internacional sobre a cultura digital.

O evento é aberto ao público e busca expandir seu alcance educacional, compartilhando experiências conquistadas com o FILE por meio de tecnologias de educação, comunicação, registro e memória.

Ao longo dos anos, o FILE foi constituindo um arquivo com mais de dois mil trabalhos digitais, produzidos por artistas de trinta e oito países diferentes. Esse arquivo conta com diversos tipos de suporte como cd-roms, disquetes, video-tape, textos e catálogos. Esse arquivo tem o potencial de oferecer um grande panorama de tudo o que foi apresentado em novas mídias desde o ano 2000 pelo festival, que disponibiliza on-line o material de web-art de seu acervo.

O festival também promove o evento Hipersônica, uma ramificação sonora e musical que visa elaborar conexões entre os universos das imagens, textos e sons e ampliar as atividades artísticas do festival.

A área de hipersonoridades, poesia sonora, esculturas sonoras e antimúsica, identifica estilos e tendências, apresentando abstrações e performances derivadas 
das inter-relações com videografismo, game-art, teatro eletrônico e música digital experimental.

O evento conta também com o FILE Labo, um laboratório multimídia que tem como objetivo o desenvolvimento, pesquisa e experimentação de trabalhos multidisciplinares no campo das novas mídias. Ele oferece ambiente para pesquisa e desenvolvimento em uma plataforma de colaboração entre artistas nacionais e internacionais, programadores, cientistas e pesquisadores.

A infraestrutura dos laboratórios foi desenhada para dar suporte a projetos de arte que utilizam diversos tipos de tecnologia: realidade aumentada, instalações interativas, instalações sonoras, vídeo performance, robótica experimental, intervenções urbanas, entre outros.

O laboratório busca estabelecer relações de cooperação cultural e tecnológica por meio de intercâmbios e residências entre as comunidades artísticas nacionais e internacionais, inserindo sua produção no contexto de pesquisa e desenvolvimento mundial, compatível com a mentalidade tecnológica e artística da contemporaneidade.

\subsection{Novos rumos no cenário internacional}

Este trabalho ficaria incompleto se não tratasse de relacionar os exemplos tratados anteriormente com outros que sirvam de contraponto e auxiliem a desenvolver reflexões sobre os fenômenos descritos. Por isso foram selecionados exemplos de museus internacionais que contribuem para a discussão e apresentam diferentes abordagens que ajudam a formar um pequeno conjunto comparativo.

Se em 1977 o Centro Georges Pompidou apresentou uma nova tipologia 
arquitetônica e a intenção de abrir o museu e incorporá-lo à vida urbana, associando serviços, lojas e restaurantes, na década de 1990 o Guggenheim de Bilbao (figura 28) de Gehry revelou um repertório formal que tornou o museu um marco na história da arquitetura. Concluído em 1997, o museu logo se tornou um paradigma deste momento e transformou a antes pouco conhecida cidade espanhola de Bilbao em destino turístico bastante procurado.

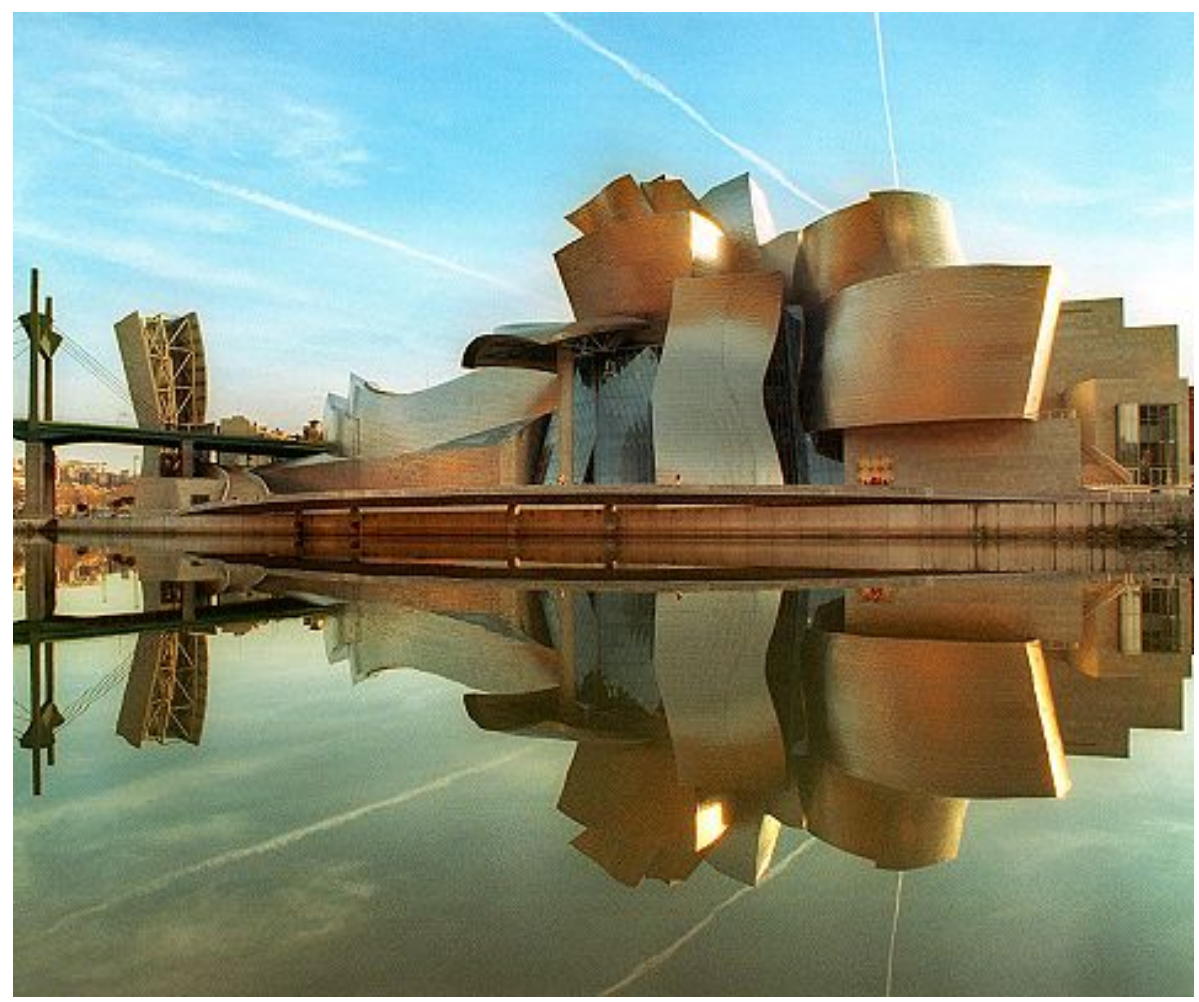

Figura 28. Museu Guggeinheim, Bilbao, 1997.

Em uma direção distinta e com um apelo formal menos extravagante, os escritórios de Herzog \& de Meuron, e Kazuyo Sejima + Ryue Nishizawa (SANAA) têm apresentado novas abordagens para a arquitetura dos museus. No 21 st Century Museum of Contemporary Art, na cidade de Kanazawa, Japão, eles praticamente inauguraram uma nova categoria de museu e talvez ele se torne um novo paradigma para os próximos museus deste início de século. 
Com desenho ortogonal e menos rebuscado que o museu de Gehry (figura 29), os arquitetos japoneses romperam a hierarquia rígida imposta por uma entrada principal e criaram diversas entradas que dialogam com o entorno e as ruas da cidade, conduzindo ao átrio central de caráter monumental.

Segundo dados do museu (www.kmm.nl/), em seus primeiros dez meses de funcionamento, foram contabilizados 1,2 milhões de visitantes, incluindo a do próprio Frank Gehry, que declarou posteriormente as qualidades de ser um museu aberto e democrático. Segundo o arquiteto: "Isto é o que todos nós tentamos alcançar nos museus, embora nem sempre com sucesso. Ele é como o Millenium Park em Chicago (2004), onde as esculturas atraem e envolvem as pessoas".

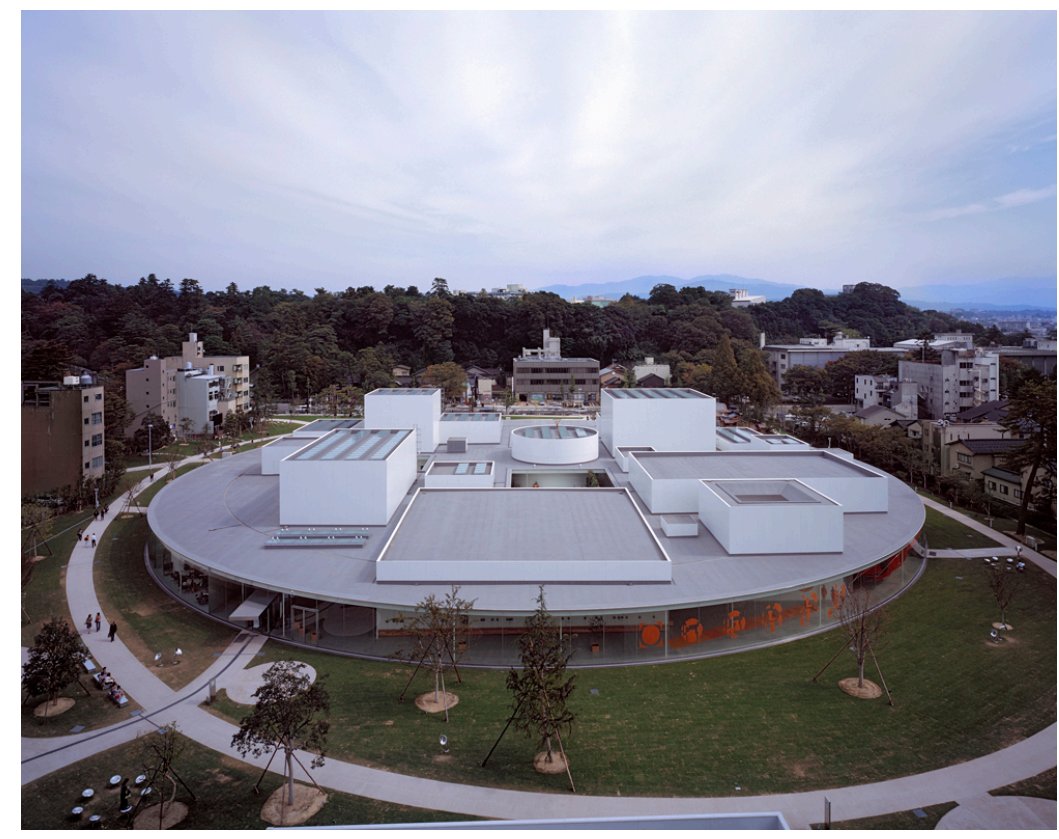

Figura 29. SANAA, 21st Century Museum of Contemporary Art, Kanazawa, Japão, 2004.

O Millenium Park (2004) é um tipo de parque urbano que agrega diversos usos e serviços, explorando a criação de espaços com obras que interagem com as pessoas, como a Crown Fountain, que é um tipo de vídeo-escultura, criada em 
homenagem à família Crown, de importante tradição e poder econômico de Chicago, pelo artista catalão Jaume Plensa e inaugurada em julho de 2004.

A fonte é composta duas torres de tijolos de vidro com painéis de LED acoplados que exibem vídeos digitais em suas faces. Os vídeos dialogam com a água que é lançada, formando um chafariz para as pessoas brincarem e se refrescarem nos dias de calor. A interação acontece de maneira lúdica e usa a água como elemento que envolve os sentidos e atrai a participação do público (figura 30).

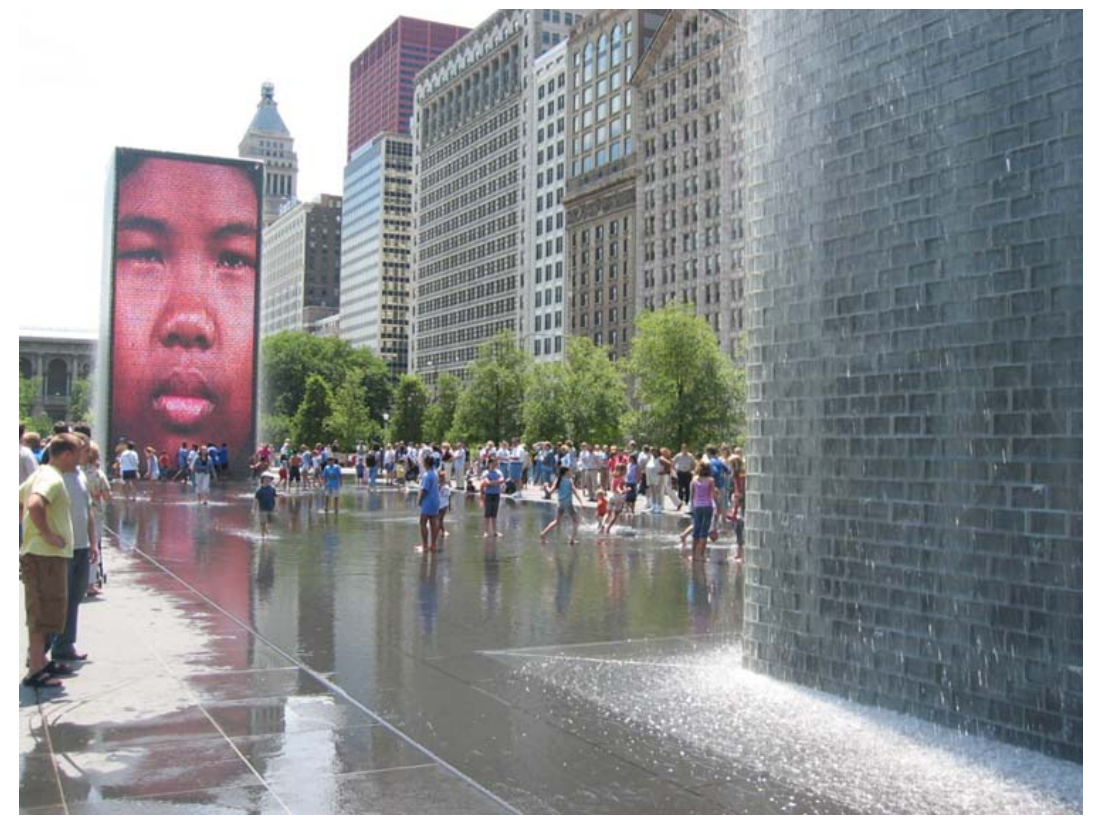

Figura 30. Crown Fountain, Millenium Park, Chicago, 2004.

O conceito de museu interativo integrado à cidade tem apresentado resultados positivos e demonstrando diferentes possibilidades para novos projetos.

Neste caso, o museu não corresponde ao "cubo branco" como objeto isolado do mundo exterior, onde a iluminação é, na maioria das vezes, artificial. Alguns museus estão se abrindo para a cidade, utilizando a luz natural e aproveitando as vistas para o exterior. Além disso, acontecem programações em espaços públicos, 
com obras desenhadas para lugares específicos (site-especific art), buscando se aproximar do cotidiano das pessoas.

Entre tantas transformações e devido à variedade de suportes e mídias utilizados pelos artistas, o conceito de flexibilidade é um dos principais desafios para os arquitetos que buscam abrigar a maior diversidade possível de obras e possibilitar a reorganização do espaço atendendo às necessidades técnicas e de uso da exposição. A concepção de grandes espaços com sistemas de iluminação e divisórias móveis é muito utilizada e mantém neutralidade em relação aos objetos expostos.

A questão da mobilidade também foi retomada pelo escritório OMA em colaboração com Rem Koolhaas no projeto Transformer (Seoul, 2009) para a grife de moda Prada. Os arquitetos criaram uma estrutura metálica formada por formas geométricas simples (círculo, retângulo, cruz e hexágono) que pode ser transportada e muda sua função de acordo com o lado que é colocado no chão, gerando quatro plantas diferentes.

O edifício é "embrulhado" por uma lona branca de vinil que se ajusta às incongruências e arestas da estrutura e dá transparência ao museu. À noite a lona permite ver as luzes e sombras em seu interior e o museu se ilumina em meio à paisagem como uma luminária gigante e durante o dia filtra a luz do sol e projeta as sombras das nuvens e árvores do exterior (figura 31).

Esta mistura inusitada entre a rigidez do aço e a elasticidade do plástico cria uma tensão, que se repete na assimetria das formas da estrutura. A ideia de uma membrana ou pele que envolva e vista a estrutura como uma roupa faz um jogo com a função do edifício e mostra que a flexibilidade pode ser alcançada com um desenho menos previsível, gerando possibilidades espaciais diferentes e 
atendendo à diversidade de usos do programa, que inclui cinema, passarela para desfiles e espaços de exposições (figura 32).

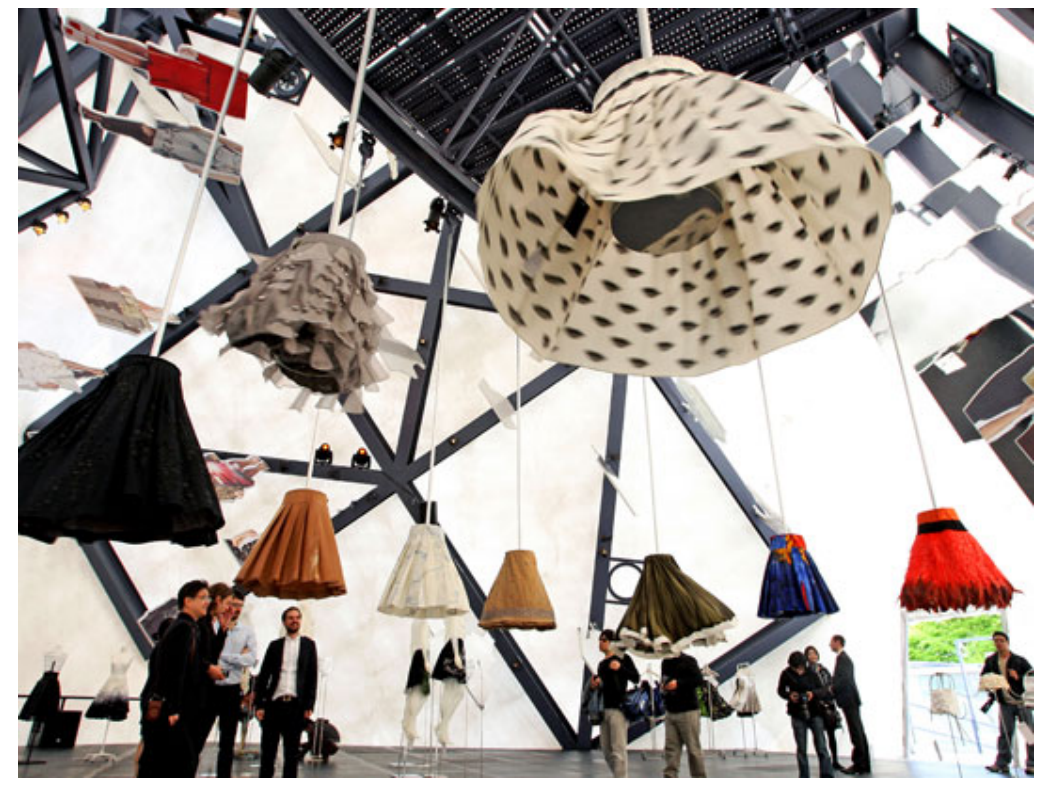

Figura 31. Foto do interior do museu Transformer mostra aspectos do espaço expositivo e a luz filtrada pela membrana plástica.

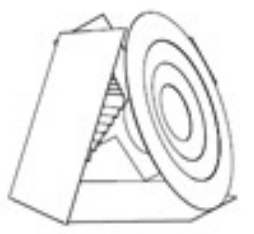

FASPOCN EOAMTICN

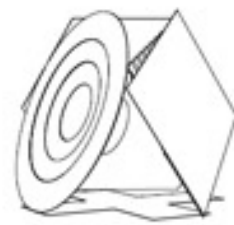

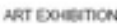

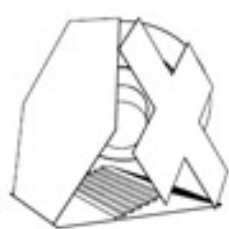

cacke

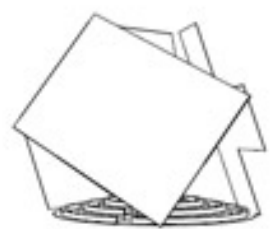

secierevert

Figura 32. Desenho mostra as quatro configurações possíveis do museu de acordo com a face que fica voltada para baixo.

O projeto de museus é complexo e sua manutenção depende de conhecimentos e contratação de serviços especializados, que incluem a criação do conceito do museu, o desenho de suas obras e exposições e a construção dos equipamentos e instalações. 
A empresa britânica MJC2 (www.mjc2.com/Frameset_products_atease.htm), por exemplo, é especializada no desenvolvimento de softwares de logística e otimização para museus e produz um guia interativo que possibilita ao visitante programar sua visitação conforme um tema de preferência ou tempo disponível para o passeio.

Desse modo o visitante tem a liberdade de escolha e pode traçar seu percurso de maneira alternativa, conforme suas preferências. Este sistema demonstra um avanço em relação aos meios mais comuns como os guias em áudio, apresentando maior interatividade e recursos de som e imagem, além de dispor de câmeras e sensores de movimento.

O sistema usa a tecnologia wireless para acessar um banco de dados com todas as informações relativas ao local registrado e os visitantes podem receber notificações sobre mostras e apresentações, além de poder reprogramar a visita de acordo com algum interesse específico.

Algumas tecnologias se tornaram recorrentes e isso se deve ao domínio da técnica e dos equipamentos e os artistas e programadores buscam explorar todas as possibilidades para criar obras interativas relacionadas ao tema do museu.

Um exemplo que aparece em diversos museus (inclusive no Museu da Língua Portuguesa e no Museu do Futebol) é o chamado piso interativo, composto por projetores que projetam imagens no chão (eventualmente mesas, paredes ou outras superfícies) e sensores de infravermelho que rastreiam os movimentos das pessoas e fazem as imagens regirem sobre elas.

$\mathrm{Na}$ figura 33, é mostrada uma aplicação desenvolvida pela empresa Arcstream AV (www.arcstramav.com), no Science Museum em Londres (www.sciencemuseum.org.uk), onde foi explorada a interatividade para criar 
mensagens de conscientização ambiental.

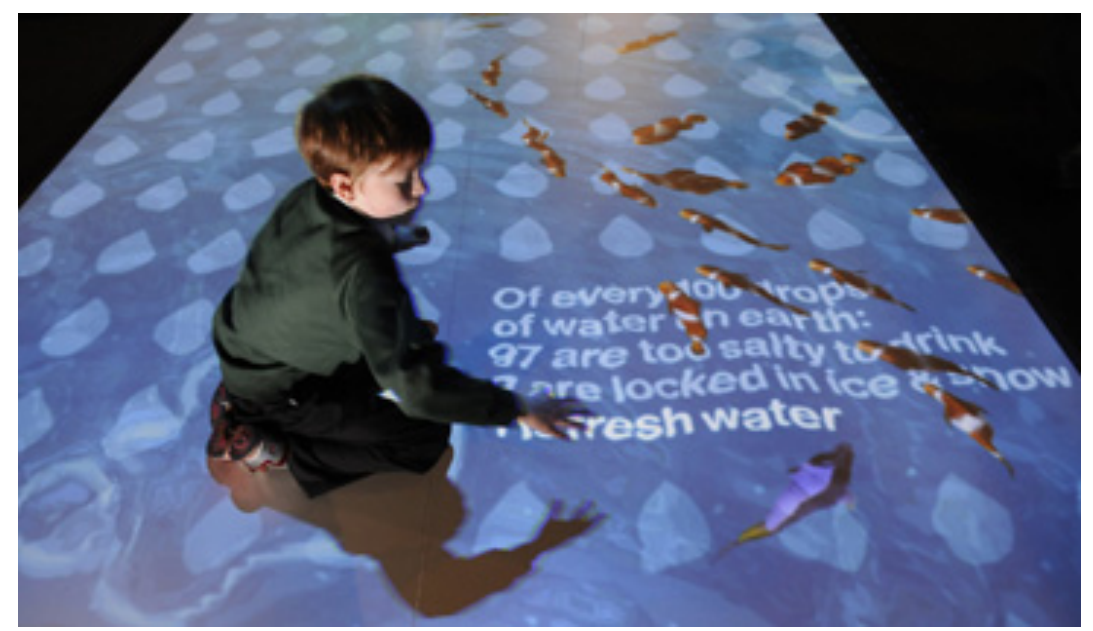

Figura 33. Uso de piso interativo durante a exposição The Science of Survival no Science Museum. Londres, 2008.

Este exemplo mostra a mesma tecnologia no Museu de Arte de Denver (www.denverartmuseum.org), em que uma "mesa de toque" (figura 34) foi instalada nas alas destinadas à pintura europeia, permitindo que o visitante navegue pela tela para acessar imagens ampliadas das obras com alta resolução e conteúdo interativo.

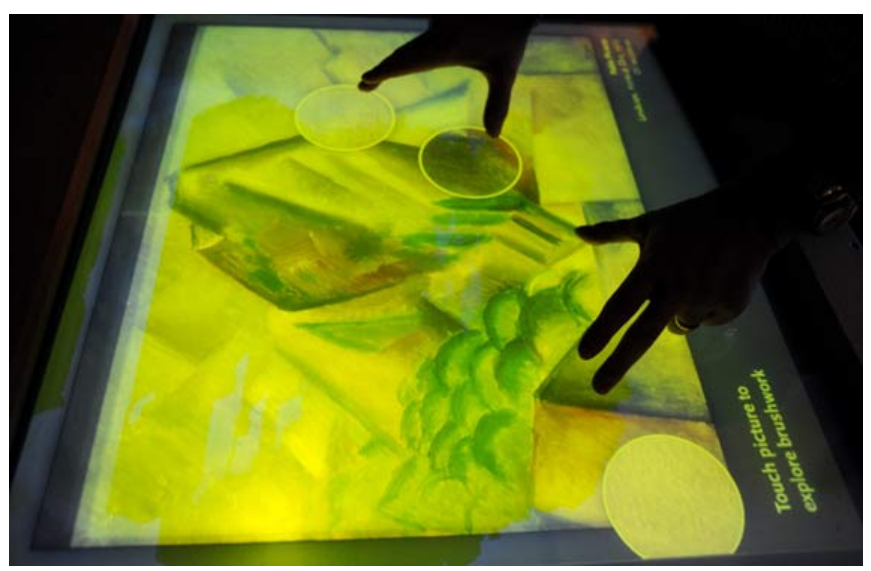

Figura 34. Mesa sensível ao toque do Museu de Arte de Denver utiliza a interação para mostrar detalhes de uma obra de Degas. 
Esta mesma tecnologia pode ser vista inclusive no Brasil, aplicada na obra Beco das Palavras (figura 35) do Museu da Língua Portuguesa, idealizada pelo artista multimídia Marcelo Tas, a obra é um jogo de juntar palavras interativo que brinca com a etimologia das palavras e seu conteúdo semântico.

Existem sistemas de projeção que podem mapear e projetar sobre superfícies curvas e objetos tridimensionais. A tecnologia 3D Mapping é utilizada para criar projeções sobre edifícios e objetos arquitetônicos da cidade, emprestando movimento e animação às fachadas estáticas dos edifícios e novos serviços e conteúdos oferecidos via Internet estão sendo oferecidos, como, por exemplo, a transmissão ao vivo de eventos ou no acesso às obras do acervo.

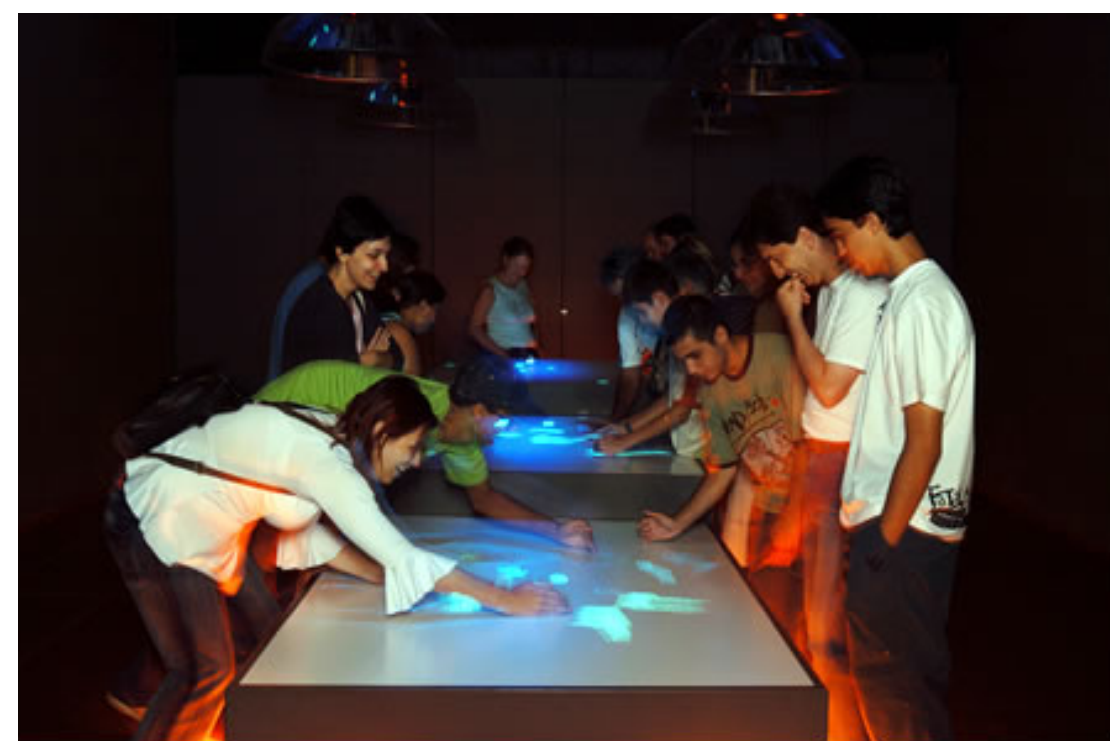

Figura 35. Mesa interativa na instalação Beco da Palavras, idealizada pelo artista multimídia Marcelo Tas para o Museu da Língua Portuguesa em 2006.

Em 2010 o Google criou um serviço gratuito online chamado Art Project (www.googleartproject.com), que permite passeios virtuais por alguns dos maiores museus do mundo, como o Museu Van Gogh em Amsterdam, a National Gallery de 
Londres, o Palácio de Versalhes na França e o Museu de Arte Moderna de Nova Iorque (MoMa).

Um equipamento com câmeras e sensores de posicionamento faz o mapeamento do espaço, registrando imagens em 360 graus, que depois são montadas e permitem que a pessoa navegue pelo espaço de uma forma bastante realista.

As principais obras foram escaneadas em altíssima resolução e revelam detalhes que seriam impossíveis de serem notados a olho nu ou na perspectiva do observador. É possível, por exemplo, escrutinar cada pincelada de Van Gogh em sua pintura O Quarto (1888), acompanhando a textura e as rachaduras das grossas camadas de tinta atingidas pelo efeito do tempo.

A navegação por espaços construídos digitalmente (seja em 3D ou com tecnologias de fotomontagem) está bastante acessível e disponível para aplicativos via web que contribui para diversas aplicações relacionadas principalmente ao turismo e à educação. Além disso, houve um aumento significativo de dispositivos 3D nestes últimos anos (videogames, TV's e computadores) com uma tecnologia mais aprimorada e a produção de conteúdo em 3D, principalmente no cinema e na indústria de games.

Os dispositivos móveis alteraram a forma de interação e comunicação das pessoas e inauguraram a era "pós-PC", com a portabilidade e presença de sistemas operacionais em todos os equipamentos e eletrodomésticos. Além disso, a conectividade entre eles e a internet permite que todos os dados sejam sincronizados e fiquem disponíveis de qualquer lugar e a qualquer momento.

Os visitantes dos museus vêm encontrando cada vez mais recursos de tecnologia interativa espalhados entre as peças de belas artes que as instituições 
expõe.

No caso do museu de Denver, as tecnologias utilizadas não são altamente sofisticadas e buscam simplicidade e facilidade de manutenção dos equipamentos, já que um dos maiores desafios é manter tudo funcionando corretamente.

A postura adotada pelo museu foi combinar arte e tecnologia e compartilhar suas estratégias e exposições com outros museus a fim de criar uma rede colaborativa entre as instituições que centralize as buscas e facilite as trocas de experiências e parcerias.

Os museus de ciência e tecnologia foram os primeiros a explorar o uso de obras interativas para conciliar aprendizagem e entretenimento e embora os museus de arte tenham resistido durante um tempo, tiveram que ceder espaço para o uso de novas tecnologias e incorporar estes recursos para melhorar sua comunicação com o público e auxiliar no conhecimento e interpretação das obras.

Além de toda a criatividade necessária à produção das interfaces e sistemas interativos, um dos maiores desafios é mantê-los em funcionamento com a manipulação de milhares de visitantes e o uso algumas vezes inapropriado dos equipamentos.

Para o professor de arte e comunicação digital Cícero Inácio da Silva, a obsolescência dos equipamentos e dos conteúdos é algo sempre a se ponderar, além da tendência a se criar obras muito redutoras, simplificadoras, que acabam depreciando o uso das tecnologias. Como ainda não temos uma tradição de incorporar esses processos reflexivos aos museus, isso acaba gerando resistências (SILVA, 2012, entrevista em anexo).

Para complementar os serviços e oferecer uma experiência prévia do acervo do museu, os sites na internet estão se tornando canais importantes de pesquisa 
para os visitantes e servem para que as pessoas possam saber o que vão ver e programar melhor a sua visita.

Alguns museus criaram sites com digitalizações 3D de suas peças e disponibilizaram parte de seu acervo publicamente pela internet. $O$ projeto do Museu Virtual do Iraque desenvolvido pelo Conselho Nacional de Pesquisa da Itália (CNR), trabalhou na elaboração de ambientes virtuais para a navegação do internauta e apresenta uma animação que simula o surgimento da civilização no Iraque.

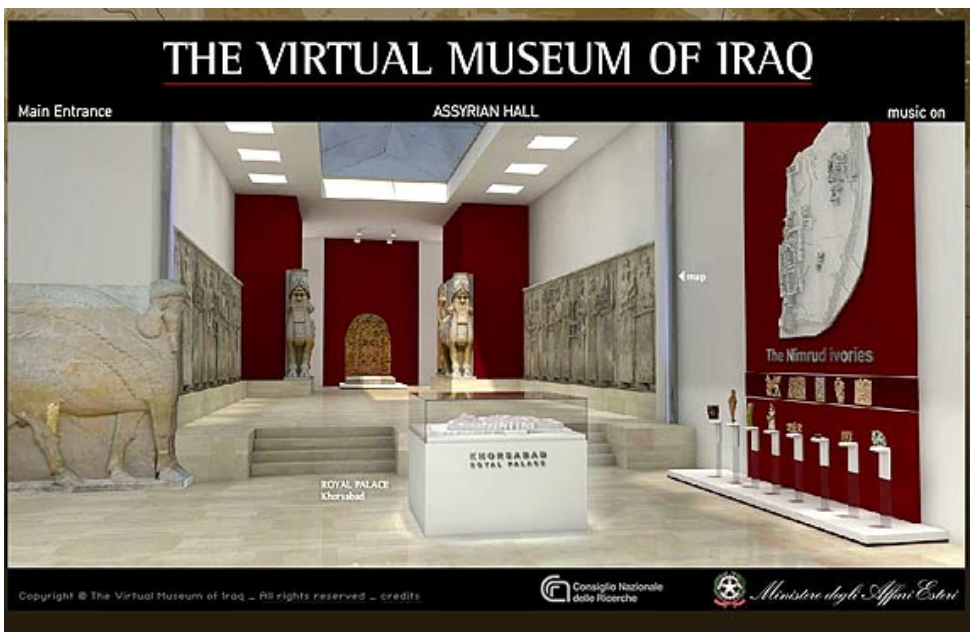

Figura 36. Um dos ambientes virtuais do Museu Virtual do Iraque (www.virtualmuseumiraq.cnr.it)

O Museu Nacional do Iraque, fundado em 1926 na cidade de Bagdá, tem seu acervo considerado o quarto mais importante do mundo. O projeto de criação do site contou com o trabalho de uma equipe de mais de cem profissionais, entre arqueólogos, pesquisadores e especialistas e apresenta um total de 70 peças, das quais 40 com modelos $3 \mathrm{D}$, além de vídeos e mapas que mostram as transformações dos sítios arqueológicos. O museu virtual foi dividido e organizado em oito salas, correspondentes às oito eras da Mesopotâmia, onde o internauta pode acessar informações e interagir com as peças em 3D (figura 36). 
Na Inglaterra, um dos países com maior quantidade de museus do mundo, foi criado o projeto National Museums Online Learning Project, que oferece busca em um banco de dados unificado com todas as instituições associadas, além de consultas sobre a programação de eventos e exposições.

Foi criado um site que reúne as obras dos museus (Museu Vitória e Alberto, National Portrait Gallery, Natural History Gallery, Tate, Wallace Collection, Royal Armories, Sir John Soane's Museum e Imperial War Museum) em forma de rede social organizada por assuntos de interesse, como escolas artísticas, autores, momentos históricos, etc. A comunicação com o público via internet aumenta consideravelmente o número de visitantes, pois facilita a programação da visita e o contato prévio com o conteúdo das exposições.

O Museu de Arte Moderna de San Francisco, por exemplo, oferece um serviço de podcasts (http://www.sfmoma.org/education/edu_podcasts.html) que apresenta entrevistas com áudio e vídeo de artistas e curadores que guiam os visitantes, explicando as exposições. Os podcasts podem ser carregados pela internet em um tocador de MP3 ou pela rede wi-fi do museu.

Talvez isso leve ao desenvolvimento de aplicativos para que os espectadores possam contribuir com sugestões e críticas e influenciar nas exposições, eventos e serviços oferecidos pelos museus, gerando redes sociais participativas.

Observando o incremento no volume de visitantes após a criação de sites e conteúdos para a internet, os museus passaram a explorar novos canais de comunicação e utilizar redes sociais como Facebook, Youtube e Flickr para se popularizar e interagir com o público. Desse modo, as pessoas ficam sabendo das exposições, recomendam a visita para seus amigos e compartilham textos, vídeos e imagens de maneira informal em comunidades sobre o artista ou assunto de 
interesse.

As redes sociais e seus serviços de compartilhamento se tornaram um dos maiores negócios para a internet e sua forma de interagir e trocar informações com seus amigos transformou o comportamento social na rede. Os artistas e curadores estão percebendo isso e procurando formas de utilizar estes recursos para manter a conexão com o público.

Além dos recursos disponíveis pelos sites dos museus, tecnologias mais caras são empregadas para oferecer experiências imersivas e a realidade virtual é uma tecnologia que se desenvolveu muito na primeira década deste século, devido à expansão de seu uso principalmente pela indústria de games e cinema. Nos museus diversas obras e instalações passaram a utilizar sistemas 3D e simuladores para criar ambientes virtuais, reconstruir cenários e contextos históricos e envolver o público.

Em Roma, no centro cultural Fundação Mundo Helênico (www.fhw.gr/fhw/index.php?lg=2), foi utilizada esta tecnologia para transportar as pessoas por uma representação da antiga Atenas, viajando pelo tempo e acompanhando as mudanças da cidade e de suas construções no decorrer de mais de dois mil anos.

Para navegar por este mundo virtual foram criados avatares (representações 3D, ou "corpos virtuais"), que permitem interagir com outras pessoas e objetos no mundo virtual.

No Centro Cultural do Mundo Helênico foi construída uma sala virtual para projeções em 3D que exibe um vídeo descrevendo o início da civilização ocidental, com suas cidades, monumentos arquitetônicos e paisagens naturais. A sala, chamada Tholos (figura 37), conta com cento e trinta lugares e possui um teto em 
forma de cúpula onde 12 projetores criam imagens estereoscópicas em 180 graus que favorecem a sensação imersão.

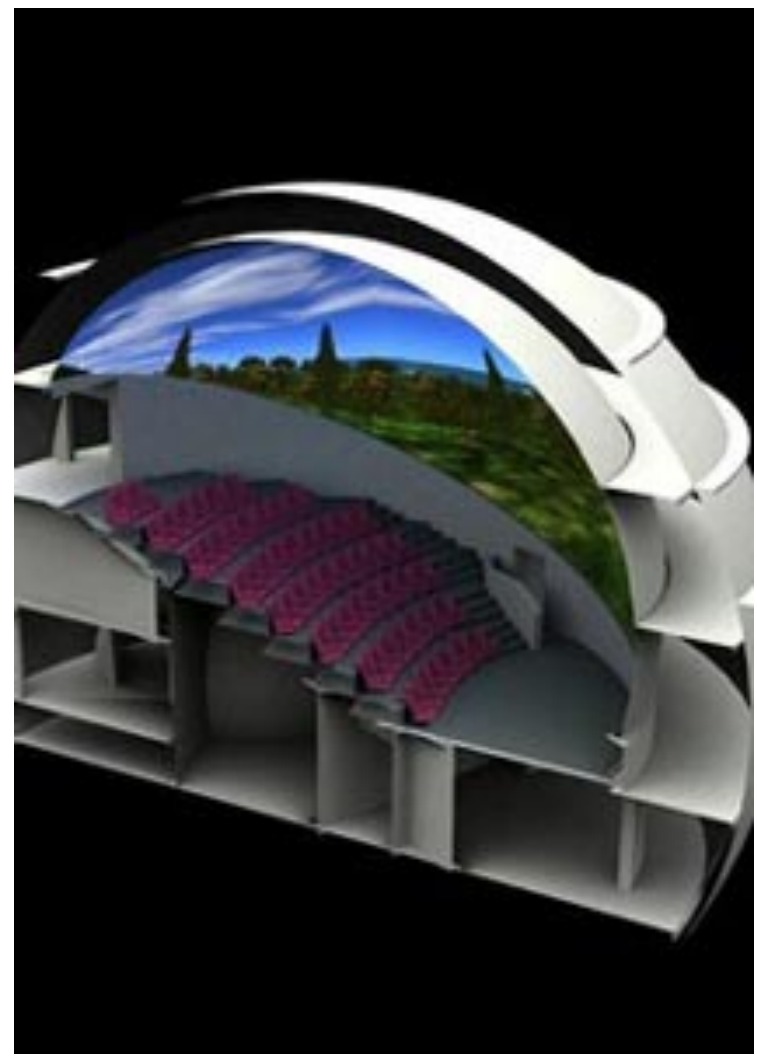

Figura 37. Maquete do Tholos mostra a cúpula de projeção da sala.

Em termos arquitetônicos, o Tholos é uma atualização do conceito do planetário, mas neste projeto além da reprodução de conteúdo pré-gravado, a tecnologia empregada permite a interação em tempo real com os ambientes virtuais, ampliando as possibilidades e aplicações para este tipo de sala.

Os museus têm ampliado seus serviços para interação com o público via internet e alguns oferecem visitas virtuais e reproduções das obras em 3D, além de informações e links de conteúdos relacionados às obras. Um exemplo é o museu Reina Sofía (www.museoreinasofia.es), de Madri, que disponibilizou visita virtual a 
seus edifícios históricos e exposições periódicas.

Um problema recorrente enfrentado pelos museus que estão reproduzindo conteúdo na internet é com relação às restrições de direitos autorais, o que impede a exposição de algumas obras. Neste caso, o site serve como uma visita prévia do museu, auxiliando na compreensão da organização do espaço das exposições, no planejamento da visita e na localização das obras e instalações de interesse.

Houve um grande aumento na produção de arte interativa e um fator importante é que os equipamentos e recursos tecnológicos se tornaram mais acessíveis, aumentando a produção, transmissão e reprodução de conteúdo nos mais variados formatos.

Na primeira década do séc. XXI, com a viabilização e aumento da produção de arte digital e o uso da internet na comunicação com o público, muitos museus tiveram que se adaptar a esta mudança de paradigma. As TIC's provavelmente serão a base da produção das próximas gerações de artistas e a internet pode ser o caminho para a criação de verdadeiros "museus sem paredes".

Em meados dos anos 1990, a arte audiovisual se ampliou e o modelo da "caixa preta" se tornou uma alternativa para abrigar este tipo de arte, assim como o "cubo branco" foi, na década de 1970, o modelo para a arte moderna. Isso pressupõe uma mudança na organização do espaço e uma alteração na forma com que os espectadores percorrem as exposições e interagem com as obras.

Os museus foram eliminando suas paredes e divisórias e deixando o percurso menos controlado, permitindo que as pessoas façam seu próprio caminho. Existe uma inversão na forma de se relacionar com a arte, que exige postura aberta do público para experimentar e tocar o objeto, diferente do que apenas contemplá-lo à distância. 
As transformações tecnológicas da última década aprofundaram a importância da comunicação e da informação com a consolidação dos sistemas digitais. O que parece ser o maior campo de pesquisas e desenvolvimento neste início do século é o aperfeiçoamento da experiência com a interface dos dispositivos e isto se refletiu diretamente no campo da arte e dos museus.

A presença de instalações interativas e terminais multimídia se tornaram itens quase obrigatórios tanto nos novos museus como nos museus existentes. As tecnologias são utilizadas tanto para dialogar com o público como para demonstrar a modernização do museu e manter uma linguagem mais próxima das novas gerações, acostumadas a esses tipos de interface com a informação.

Evidentemente essas estratégias têm um objetivo maior que é atrair mais visitantes para gerar receita e possibilitar a manutenção do museu, ampliação, e geração de lucro para os investidores (no caso de empreendimentos privados).

A definição da identidade do museu e a maneira de se comunicar com o público são fundamentais para seu sucesso e os administradores de museus realizam pesquisas e campanhas de marketing para planejar suas exposições e dar visibilidade pública. A comunicação visual e promoção midiática das exposições contribuem para atrair mais visitantes e viabilizar financeiramente os investimentos.

Tanto o Museu do Futebol como o Museu da Língua Portuguesa exploram temas que representam a cultura nacional tanto para brasileiros como para estrangeiros. Esse planejamento é realizado anteriormente por empresas especializadas que estudam o potencial de investimento e estabelecem as diretrizes do projeto e concepção da exposição, desenvolvendo inclusive as obras e instalações.

Esse mercado tem atraído a atenção de investidores que perceberam a 
potencialidade de retorno dos investimentos associando sua imagem à cultura e à tecnologia. O setor cultural vem tornando-se cada vez mais importante nas políticas de gestão das grandes cidades, pois tem a força para atrair recursos, incrementar o turismo e gerar visibilidade. Isto faz com que grandes empresas e instituições direcionem parte de seus investimentos na criação de projetos ou institutos culturais, utilizando muitas vezes incentivos fiscais e leis de apoio à cultura.

As instituições europeias que deram origem aos centros de produção, foram concebidas exclusivamente com financiamento público, possibilitando uma abordagem diferenciada, mais crítica e independente de fatores econômicos e comerciais. Por outro lado, os EUA desenvolveram a relação das novas tecnologias com o entretenimento e o comércio, o que lhes rendeu a geração de grandes recursos e aumentou significativamente os investimentos em pesquisa e desenvolvimento feitos pelo capital privado.

No Brasil, existe uma demanda enorme no âmbito das políticas culturais, pois falta espaço de articulação e convergência de projetos para isso. Existem algumas instituições como o Observatório de Políticas Culturais da ECA-USP e o Observatório da Cultura do Minc, que têm o papel de desenvolver estudos sobre as características do mercado cultural brasileiro e fomentar investimentos e políticas culturais.

Em 2011 foi criado o Observatório Itaú Cultural, que realizou um encontro internacional para orientar suas diretrizes e reunir diversos especialistas que relataram suas experiências em observatórios culturais e órgãos similares em outros países. Um dos pontos cruciais está em manter a ética do observatório, independentemente de ser patrocinado por um banco ou instituição privada.

A tendência é lidar com a cultura não mais como um problema setorial, mas 
como um fator diretamente relacionado às diretrizes de desenvolvimento social e democracia. Assim, a cultura se tornará cada vez mais um fator de legitimidade e de identidade para as sociedades e considerada um dos indicadores de desenvolvimento do país.

\section{Considerações Finais}

Esta pesquisa formulou um quadro sobre a problemática dos museus na contemporaneidade e forneceu importantes dados para ampliar a visão sobre as relações que esse espaço pode estabelecer em seus distintos níveis de interface com a sociedade.

O percurso histórico e as transformações ideológicas que transformaram os museus proporcionaram reflexões que serviram para a compreensão dos múltiplos significados que esta instituição agrega, com exemplos que ilustram e complementam as análises.

No percurso histórico realizado ficou evidente o deslocamento do campo de ação da obra de arte, do suporte estático e bidimensional da parede, para se projetar pelo espaço tridimensional do museu e envolver os sentidos do espectador.

Paralelamente a isso ocorreu um novo direcionamento no processo criativo, que fez com que a obra estabelecesse uma relação dinâmica com o público, expondo a relação artista-arte-espectador e criando os conceitos de instalação, obra aberta e interação.

Com a inexorável evolução das técnicas e ferramentas utilizadas pelo artista para criar e produzir o seu trabalho, atualmente as TIC's se tornaram parte do repertório e foram incorporadas como reflexo de inserção na era da sociedade da 
informação.

A pesquisa aponta para a formação de um tipo de espaço informacionalcomunicativo e interativo direcionado à produção cultural artística que abre novas possibilidades e desafios para os atores envolvidos.

A sistematização dos conceitos, tanto na esfera artística como na arquitetônica, revelaram a riqueza de possibilidades que as TIC's podem proporcionar nessa nova dimensão que os espaços culturais estão assumindo.

Artistas, arquitetos e curadores são os principais agentes dessas transformações, pensando e desenhando suas obras dentro de um sistema de interfaces e fluxos de informações e lançando novos olhares para ampliar as formas de interação com a arte.

Para que ocorram tais transformações é imprescindível e inevitável que haja a troca de conhecimentos e o trabalho colaborativo e transdisciplinar entre os artistas, técnicos, historiadores, arquitetos e especialistas.

A partir do quadro conceitual obtido e das análises e estudos sobre arte interativa, novas mídias e museus, foi possível estabelecer os critérios para selecionar os estudos de caso e fornecer parâmetros para compreender a conjuntura da arte interativa e suas principais linhas de atuação e pesquisa em uma abordagem historiográfica.

A escolha dos objetos de estudo também levantou reflexões sobre as políticas culturais praticadas e forneceu referências para a discussão no campo das artes eletrônicas no Brasil.

Há ainda dúvidas não respondidas sobre os caminhos a serem percorridos pelos eixos curatoriais em arte eletrônica, sobre como exibir esses trabalhos e organizar o espaço expositivo/interativo. Há questões conceituais que ainda estão 
sendo discutidas sobre a concepção de novos espaços museográficos, sem que haja uma definição amplamente estabelecida.

No entanto, pode-se concluir a partir deste estudo que o conceito de interatividade dificilmente será suprimido da arquitetura e que as tecnologias atuais ampliam as possibilidades e permitem uma integração maior dos elementos da arquitetura, tanto do softspace como do hardspace.

O museu existe apenas há dois séculos e a nossa relação com as obras de arte se transformou radicalmente neste período, ele representa a convivência das mais diferentes representações do mundo e é um dos lugares onde estão reunidas as maiores obras-primas produzidas pelo homem.

Esta pesquisa buscou contribuir para o complexo campo de conhecimento que permeia a arte, o museu e a tecnologia, alimentando o debate e fornecendo material para futuras pesquisas sobre o assunto. 


\section{REFERÊNCIAS BIBLIOGRÁFICAS}

ASCOTT, Roy; LOEFFLER, Carl (org.), Dossier: "Connectivity: Art and Interactive Telecommunications" in Leonardo, vol.24, n.2, 1991.

BACHELARD, G. A Poética do Espaço. Coleção Tópicos. São Paulo: Martins Fontes, 1993.

BAUDRILLARD, Jean. The Ecstasy of Communication. New York: Semiotext(e), 1988.

BAUDRILLARD, Jean. Simulations. New York: Semiotext(e), 1983.

Bender, Gretchen and Tymothy Druckrey, eds. Culture on the Brink: Ideologies of Tecnology. Seattle: Bay Press, 1993.

BIOCCA, F., \& Delaney, B. Immersive virtual reality technology. Hillsdale, NJ: Lawrence Erlbaum and Associates, 1995.

BIOCCA, F. Cyborg's dilemma: Progressive embodiment in virtual environments. Journal of Computer Mediated-Communication [On-line], 1983.

BRAND, S. The media lab : inventing the future at MIT. New York : Viking Penguin Inc. , 1987.

CASTELLS, M. A sociedade em rede. A era da informação: economia, sociedade e cultura. v.1. Trad. Roneide Venancio Majer. São Paulo, Paz e Terra, 1999.

COSTA, Mario, "Technology, Artistic Production and the Aesthetics of Communication" in Leonardo, vol.24, n.2, Berkeley, CA, USA, 1991.

COUCHOT, Edmond. A arte pode ainda ser um relógio que adianta? O autor, a obra e o espectador na hora do tempo real in A Arte no Século XXI: $A$ Humanização das Tecnologias, Fundação Editora da UNESP, São Paulo, 1997. 
COUCHOT, Edmond. A segunda interatividade. Em direção a novas práticas artísticas. In Arte e Vida no Século XXI - Ciência, Tecnologia e Criatividade, Diana Domingues (org.). São Paulo: Unesp, 1999.

DOMINGUES. Diana (org). A arte no século XXI: a humanização das tecnologias. São Paulo: Fundação Editora da UNESP, 1997.

DOMINGUES, Diana. Criação e Interatividade na Ciberarte. São Paulo: Experimento, 2002.

DUARTE, Fábio. Arquitetura e tecnologias de Informação: da revolução industrial à revolução digital. São Paulo: Editora da UNICAMP, 1999.

FIRMINO R. J.; MARQUES, S. L. O.; CAMARGO, A. R. Novas Tecnologias: Impactos na Forma Urbana. In: NUTAU'98 - Arquitetura e Urbanismo: tecnologias para o século XXI. São Paulo, 1998. Anais em CD-ROM. São Paulo, FAU-USP, 1998.

FRANKLIN, Benjamim L. O Ciberespaço: virtualização, desmaterialização e materialização. Online. Internet. http://www.geocities

GLEADOWE, Teresa. Curating in a Changing Climate, in Curating in the 21st Century, ed. Gavin Wade (Walsall, UK: New Art Gallery, 2000) p.29.

HORAN, Thomas A. Digital Places: Building Our City of Bits. Washington DC: Urban Land Institute, 2000.

IHDE, Don. Bodies in Technology. Minneapolis: University of Minnesota Press, 2002.

JOHNSON, Steven. Cultura da Interface. Rio de Janeiro: Jorge Zahar, 2001.

LEMOS, A. e PALACIOS, M. (orgs.) Janelas da Cibercultura. Porto Alegre, Sulinas, 2001.

LÉVY, P. Becoming Virtual: Reality in Digital Age. Nova lorque: Plenum Press, 
1998.

LÉVY, Pierre. As Tecnologias da Inteligência: O Futuro do Pensamento na Era da Informática. Rio de Janeiro: Ed. 34, 1993.

LÉVY, Pierre. O que é o Virtual? São Paulo: Ed. 34, 1996.

LÉVY, Pierre. A Inteligência Coletiva. São Paulo: Loyola, 1999.

LOJKINE, J. A revolução informacional. São Paulo, Cortez, 1995.

MACHADO, Arlindo. Máquina e imaginário: o desafio das poéticas tecnológicas. São Paulo, EDUSP, 1993.

MACHADO, Arlindo. Hipermídia: o labirinto como metáfora. A arte no século XXI. São Paulo, Ed. UNESP, 1997.

MCCULLOUGH, Malcolm. Digital Ground: Architecture, Pervasive Computing, and Environmental Knowing. Cambridge, MA: MIT Press, 2004.

MANOVICH, Lev. The Language of New Media. MIT Press, 2002.

MCLUHAN, M. Os Meios de Comunicação como Extensões do Homem. São Paulo: Cultrix, 1964.

MITCHELL, W. J. City of Bits: Space, Place, and the Infobahn. MIT Press, Cambridge, Mass., 1998.

MITCHELL, W. E-topia. The Mit Press, Mass., 2000.

MITCHELL, W. J. ME++. MIT Press, Cambridge, Mass., 2003.

MONTANER, Josep Maria. Museus para o século XXI. Barcelona, Editorial Gustavo Gilli S.A., 2003.

NEGROPONTE, Nicholas. A vida digital. S. Paulo: Companhia das Letras, 1995.

NOVACK, M. Liquid architectures in cyberspace. In M. Benedict (Ed.), Cyberspace: First steps. Cambridge, MA: MIT Press, 1991. 
NOVACK, M. Dancing with the Virtual Dervish. In: Immersed in Technology. Cambridge: MIT Press, 1996.

PARENTE, A. Imagem-Máquina. A Era das Tecnologias do Virtual. RJ: Editora 34, 1996.

PIMENTEL, K. \& Teixeira, K. The science of virtual reality: through the new looking glass. London, McGraw-Hill, 1993.

PLAZA, Julio e TAVARES, Mônica. Processos Criativos com Meios Eletrônicos: Poéticas Digitais. Editora Hucitec, São Paulo, 1998.

POPPER, Frank. L'art à l'âge électronique. Editions Hazan, Paris, 1993.

PORTER, David. Internet Culture. Routledge, London, 1997.

PRADO, Gilbertto, "As Redes Artísticas Telemáticas", in Imagens, n 3, pp. 41-44, Editora da Unicamp, dezembro, 1994.

, "Cronologia de Experiências Artísticas nas Redes de Telecomunicações" in Trilhas, n.6, vol.1, pp. 77-103, julho/dez. 1997.

"Experimentações Artísticas em Redes

Telemáticas e Web", in Arte Brasil, Pós-Graduação do Instituto de Artes, Unesp, n.1, ano 1, agosto de 1998.

SANTAELLA, Lucia. Culturas e Artes do Pós-humano. Da Cultura das Mídias à Cibercultura. São Paulo, Paulus, 2003.

SANTAELLA, Lúcia e NÖYH, Winfried. Imagem: semiótica, cognição e mídia. São Paulo, lluminuras, 1997.

SANTAELlA, Lúcia. Cultura das Mídias, 2 a ed., São Paulo, Experimento, 1996.

SANTOS, Milton. A natureza do espaço: técnica e tempo, razão e emoção. 2.ed. São Paulo, Hucitec, 1997. 
SANTOS, Milton. Técnica Espaço Tempo: globalização e meio técnicocientífico-informacional. São Paulo, Hucitec, 1994. 


\section{ANEXO}

Entrevista concedida por Cícero Inácio da Silva, pesquisador e professor na área de arte e comunicação digital, pesquisador e Professor Colaborador na Pósgraduação Stricto Sensu em Comunicação da Universidade Federal de Juiz de Fora (UFJF) e pesquisador associado ao Center for Research in Computing and the Arts (CRCA) na Universidade da Califórnia, San Diego (UCSD). É autor do livro Plato online: nothing, science and technology (All Print), coordenador do Comitê Científico do FILE e do comitê Científico do FILE Labo (Qualis A Internacional/2008).

\section{Como você vê a relação entre arte, tecnologia e interação nos museus}

\section{contemporâneos?}

CIS: A princípio, como a pergunta já parte de uma afirmação, teríamos que primeiro pensar o que seria essa "interação" e em que lugares ela acontece. Eu particularmente não a vejo, ao menos no Brasil, de forma tão intensa. Se ponderarmos, veremos que menos de $1 \%$ dos museus utilizam ou tem em seu acervo obras que demandem a "interação" do usuário ou visitante. Agora, se nos pautarmos por modelos de museus recentes, como os que você analisa em seu resumo, aí sim podemos dizer que há uma certa "tendência" ao uso de equipamentos digitais (ou de TICs como você diz) na exibição de obras. Creio que essa integração tem se dado mais a partir do sucesso de exibições e festivais, tanto no Brasil quanto no exterior, que tem como modelo as tecnologias digitais e a eletrônica. No Brasil começamos com o Videobrasil, logo depois o explosivo sucesso do FILE (Festival Internacional de Linguagem Eletrônica) e a Bienal 
Emoção Art.Ficial, do Itaú Cultural. Todos esses eventos são um hit de público e tem como base a ação do visitante e os computadores mediando boa parte da interação. Bem, agora vamos aos museus. Em que medida essa "onda" afetou essas instituições de fato? Vemos que alguns museus que tem como "objeto" alguns artefatos da mídia, como o MIS de SP, decidiram em determinado momento investir pesado nessa relação. Até o ano passado, o MIS funcionou como um Hub de eventos ligados a essa integração, até ter sua direção modificada e retomado suas origens "audiovisuais" mais conservadoras, vamos assim dizer, mas que respondem a uma certa crítica que é pontuada por aspectos dinamizadores de uma falta de compreensão mais crítica da tecnologia. Nesse sentido, a mudança de ares neste Museu da Imagem e do Som paulista se deu mais por uma dissonância na compreensão do impacto que o computador, ou o "processo computacional", vem imprimindo nas representações no campo das artes, e por consequência nos museus. Nesse sentido, o que vejo acontecendo nos museus contemporâneos é uma "incorporação" de elementos tecnológicos, por demanda de algumas representações (artísticas, de artistas, de escritores que usam kindles, Ipads ou Tablets, por exemplo) para que se exibam essas obras em seus devidos suportes. E essa exibição, por parte do administrador de uma acervo, é sempre complexa. Vou a um exemplo, descrito no meu livro Arte e Tecnologia Digital Brasileira (online): em 1970, quando foi realizada a primeira mostra de Software Arte no Jewish Museum em NY, com a curadoria de Jack Burnham (aliás um dos mais importantes críticos de arte e tecnologia que conheci), o que se discutiu nos textos do catálogo da mostra foi exatamente a questão museológica das obras. Quase todas as obras hoje são "ilegíveis" do ponto de vista de sua exibição. E isso já estava descrito nos textos do próprio curador! Ou seja, essa relação sofre, como você deve perceber, 
de uma resistência muito forte, exatamente pelos motivos que nos levam a desconfiar que algo venha a se perder por não ser mais visível ou rearticulável em um futuro não muito distante. Essas são preocupações legítimas por parte dos museus. Nesse sentido, tendo em vista que esse problema pode ser descrito, ele também pode ser pensado. Um exemplo que sempre gosto de citar é o ZKM, que tem a curadoria de um dos mais importantes pensadores do campo da arte e tecnologia, Peter Weibel. Weibel, ao aceitar ser curador do ZKM, montou um sistema "museológico" interdisciplinar, no qual seriam dadas "garantias' museológicas para a exibição de obras ao longo dos anos, com a compra de equipamentos especiais, máquinas antigas (computadores) ou máquinas de escrever etc., que fossem capazes de rodar ao longo de vários anos. Weibel conseguiu pensar isso e por na prática isso, ou seja, ele respondeu às críticas de forma prática. Nesse sentido, a crítica a essa relação, a partir do modelo do ZKM, pôde ser respondida à altura. Também acabei de vir do ISEA, em Istambul, e lá pude ver algumas dessas questões sendo tratadas. Imagine uma cidade com museus de mais de 1.500 anos, com centros culturais que datam do século $V$, entre outros, lidando agora com questões como essas? Bem, o que vi é que em muitos casos, a associação é péssima, como quando fazem projeções holográficas de figuras históricas falando para o público, o que torna a interação tanto quanto imbecilizada. Além de infantilizar muito o processo de compreensão. Apesar disso, existem várias mostras na cidade que incorporam essas tecnologias e muitas delas foram até elogiadas em artigo recente publicado no Financial Times, inclusive (http://www.ft.com/intl/cms/s/2/1c80635a-e39e-11e0-8990-

00144feabdc0.html\#axzz1ZRgIVBkw)

Bem, outro aspecto a se ponderar, e que é inclusive uma das causas dessa 
resistência é a questão corporativa envolvida com as máquinas digitais. Há ainda uma certa confusão entre "mercado" e "museus" quando da utilização de computadores, por eles serem em grande parte incompreendidos pelos críticos mais tradicionais. Quando um artista cria uma obra com um telefone celular, por exemplo, como você faz para expor isso? De que forma você trata a "marca" impressa no equipamento sem fazer alusão a um mercado? Bem, se quisermos responder a isso, basta observar as obras contemporâneas criadas com veículos que exibem também uma marca. Enfim, críticas existem, e essa tensão é sempre sadia. Agora resta ver como se pensar diante da história no longo prazo. Particularmente, eu ando bastante exausto dessas exposições que só mostram gadgets de todos os tipos, mas que não se pensam em um cenário mais amplo, tanto artístico quanto museológico. E isso talvez seja agora necessário para que a arte e tecnologia não vire uma nota de rodapé no grande livro imaginário da História da Arte e dos Museus.

\section{Quais as possibilidades para os museus com o uso das TIC's? Quais} os riscos? Quais os desafios?

Como descrevi acima, creio que as possibilidades são inúmeras. Temos que avaliar também alguns outros fatores que tencionam os museus que são: a) a proximidade dessas tecnologias com uma nova geração que começa a frequentar museus; b) a facilidade e a sedução que a "interação" proporciona; c) a familiaridade que as pessoas tem com algumas tecnologias. De que forma vemos alguns museus incorporarem isso? É realmente necessário? Creio que em alguns casos, a resposta seria positiva. Tenho em mente os museus da ciência, com seus planetários, que hoje em dia, em San Francisco, por exemplo, tem obras fabulosas 
em seus acervos, que projetam em ultradefinição fenômenos celestes simulados e com uma narrativa sedutora ao extremo que facilita, e muito, a compreensão e a visualização de coisas que antes só eram visíveis através de metáforas pouco elaboradas. E a tecnologia nesse sentido amplia de forma quase incalculável a forma como vemos o cosmo, as estrelas e como podemos interagir com esse fenômenos. Também existem obras interativas para mostrar fenômenos microbiológicos, entre outros, que trazem toda uma outra perspectiva para a exibição de obras. O que vejo são inúmeras possibilidades, mas que devem ser cuidadosamente trabalhadas, para evitar o risco de termos obras datadas e que mais infantilizam do que pensam problemas. E realizar obras com essa sofisticação geralmente custa caro, mas creio que em alguns casos, o preço é válido. Já em termos de riscos, sim, existem e são grandes. A obsolescência dos equipamentos e dos conteúdos é algo sempre a se ponderar. E também existe uma tendência a se criar obras muito redutoras, simplificadoras, que tendem a depreciar o uso das tecnologias. Como ainda não temos uma tradição de incorporar esses processos reflexivos aos museus, isso acaba tencionando o campo pelo contrário e gerando resistências.

\section{Como você vê o papel da arquitetura nos museus contemporâneos?}

Como não sou arquiteto, vou responder essa pergunta de um ponto de vista de um observador que frequenta muitos museus: eu creio que a arquitetura é fundamental quando vamos pensar em exibir alguma acervo. Vi museus, salas de concertos, realizadas por Gehry, Hadid, entre outras, que foram projetados para determinadas formas artísticas (no caso concertos e um museu acerca de uma temática nacional) e que formam parte do espetáculo ou das obras neles exibidas. 
Podemos também pensar no museu/loja/sala de concerto do Koolhas realizada para a Prada. Quando vi essa construção, ao estilo Transformer (que aliás tem o mesmo nome do filme), lembrei do texto no qual ele descreve Nova lorque como resultado de uma visualidade cinematográfica dos Penny Arcades que exibiam filmes curtos coloridos e fantásticos em Coney Island, que geraram essa arquitetura que é hoje particular à cidade. Além disso, lembro do museu da fundação do Bill Gates no MIT realizado pelo Gehry. O que dizer da vertigem que senti diante de um prédio no qual as janelas caem sobre você, no qual não há nenhum espaço "quadrado", onde tudo se move e as nossas esperanças de segurança se derretem. E isso em um museu dedicado ao "melting" da tecnologia e do software. Nesse sentido, penso que os museus estão cada vez mais sendo pensados em relação a uma "outra" configuração até de sua existência. E a arquitetura recente demonstra esse deslocamento. Como disse, o prédio Transformer do Koolhas inclusive anda...e isso é fascinante... 